\title{
Tertiary Marine Pelecypods of California and Baja California: Erycinidae Through Carditidae
}

U.S. GEOLOGICAL SURVEY PROFESSIONAL PAPER 1228-E

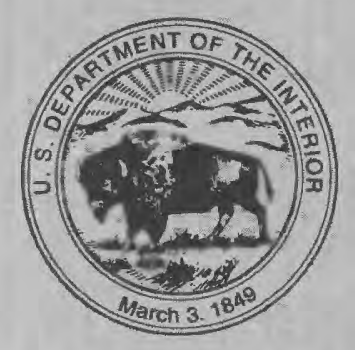




\section{AVAILABILITY OF BOOKS AND MAPS OF THE U.S. GEOLOGICAL SURVEY}

Instructions on ordering publications of the U.S. Geological Survey, along with the last offerings, are given in the current-year issues of the monthly catalog "New Publications of the U.S. Geological Survey." Prices of available U.S. Geological Survey publications released prior to the current year are listed in the most recent annual "Price and Availability List." Publications that are listed in various U.S. Geological Survey catalogs (see back inside cover) but not listed in the most recent annual "Price and Availability List" are no longer available.

Prices of reports released to the open files are given in the listing "U.S. Geological Survey Open-File Reports," updated monthly, which is for sale in microfiche from U.S. Geological Survey Book and Open-File Report Sales, Box 25425, Denver, CO 80225.

Order U.S. Geological Survey publications by mail or over the counter from the offices given below.

BY MAIL

\section{Books}

Professional Papers, Bulletins, Water-Supply Papers, Techniques of Water-Resources Investigations, Circulars, publications of general interest (such as leaflets, pamphlets, booklets), single copies of periodicals (Earthquakes \& Volcanoes, Preliminary Determination of Epicenters), and some miscellaneous reports, including some of the foregoing series that have gone out of print at the Superintendent of Documents, are obtainable by mail from

\section{U.S. Geological Survey, Book and Open-File Report Sales Box 25425 \\ Denver, CO 80225}

Subscriptions to periodicals (Earthquakes \& Volcanoes and Preliminary Determination of Epicenters) can be obtained ONLY from

\section{Superintendent of Documents \\ U.S. Government Printing Office \\ Washington, DC 20402}

(Check or money order must be payable to Superintendent of Documents.)

Maps

For maps, address mail orders to

$$
\begin{gathered}
\text { U.S. Geological Survey, Map Sales } \\
\text { Box } 25286 \\
\text { Denver, CO } 80225
\end{gathered}
$$

Residents of Alaska may order maps from

$$
\begin{aligned}
& \text { U.S. Geological Survey, Map Sales } \\
& 101 \text { Twelfth Ave. - Box } 12 \\
& \text { Fairbanks, AK } 99701
\end{aligned}
$$

\section{OVER THE COUNTER Books}

Books of the U.S. Geological Survey are available over the counter at the following U.S. Geological Survey offices, all of which are authorized agents of the Superintendent of Documents.

- ANCHORA GE, Alaska--4230 University Dr., Rm. 101

- ANCHORAGE, Alaska--605 West 4th Ave., Rm G-84

- DENVER, Colorado--Federal Bldg., Rm. 169, 1961 Stout St.

- LAKEWOOD, Colorado-- Federal Center, Bldg. 810

- MENLO PARK, California--Bldg. 3, Rm. 3128,345 Middlefield Rd.

- $\quad$ RESTON, Virginia--National Center, Rm. 1C402, 12201 Sunrise Valley Dr.

- SALT LAKE CITY, Utah--Federal Bldg., Rm. 8105, 125 South State St.

- SAN FRANCISCO, California--Customhouse, Rm. 504, 555 Battery $\mathrm{St}$.

- SPOKANE, Washington--U.S. Courthouse, Rm. 678, West 920 Riverside Ave.

- WASHINGTON, D.C.--U.S. Department of the Interior Bldg., Rm. 2650, 1849 C St., NW.

Maps

Maps may be purchased over the counter at the U.S. Geological Survey offices where books are sold (all addresses in above list) and at the following Geological Survey offices:

- ROLLA, Missouri--1400 Independence Rd.

- FAIRBANKS, Alaska--New Federal Building, 101 Twelfth Ave. 


\section{Tertiary Marine Pelecypods of California and Baja California: Erycinidae Through Carditidae}

By ELLEN JAMES MOORE

PALEONTOLOGY OF CALIFORNIA AND BAJA CALIFORNIA

U.S. GEOLOGICAL SURVEY PROFESSIONAL PAPER $1228-\mathrm{E}$

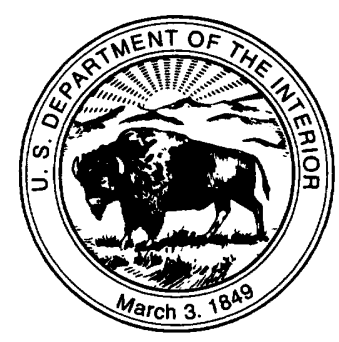

UNITED STATES GOVERNMENT PRINTING OFFICE, WASHINGTON：1992 


\section{U.S. DEPARTMENT OF THE INTERIOR \\ MANUEL LUJAN, JR., Secretary}

\section{U.S. GEOLOGICAL SURVEY}

Dallas L. Peck, Director

Any use of trade, product, or firm names in this publication is for descriptive purposes only and does not

imply endorsement by the U.S. Government

Library of Congress Catalog-in-Publication Data

Moore, Ellen James.

Tertiary marine pelecypods of California and Baja California: Erycinidae through Carditidae / by Ellen James Moore.

p. cm. - (Paleontology of California and Baja California)

(U.S. Geological Survey professional paper; 1228-E)

Includes bibliographical references and index.

Supt. of Docs. no.: I 19.16: 1228-E

1. Bivalvia, Fossil-California. 2. Bivalvia, Fossil-Mexico-Baja California. 3. Paleontology-California Mexico-Baja California. I. Title. II. Series. III. Series: U.S. Geological Survey professional paper; 1228-E. QE811.M636 1992

564'.11'09794-dc20

For sale by the Books and Open-File Reports Section, U.S. Geological Survey, Federal Center, Box 25286, Denver, CO 80225 


\section{CONTENTS}

Abstract

Introduction

Purpose and scope

Procedure

Acknowledgments -

Abbreviations

Systematics: Pelecypods-Continued from Chapter D ---.-.-

Family Erycinidae

Genus Lasaea

Family Kelliidae

Genus Kellia

Genus Aligena

Subgenus Aligena - -

Genus Bornia

Subgenus Temblornia

Family Montacutidae

Genus Mysella

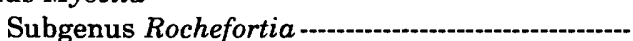

Genus Thecodonta

Subgenus Pristes

Genus Neaeromya -

Subgenus Orbitella

Family Sportellidae -

Genus Basterotia

Subgenus Basterotella

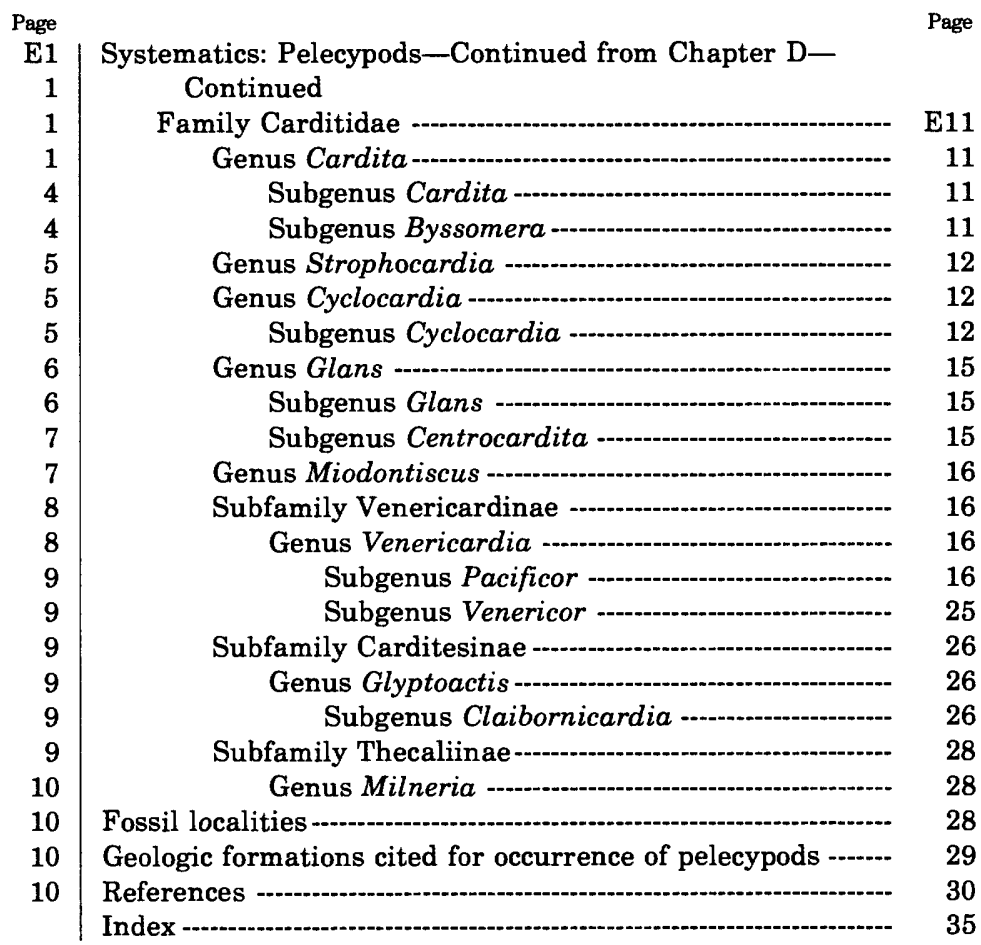

\section{ILLUSTRATIONS}

[Plates follow index]

Plate 1. Venericardia, Lasaea, Aligena, Kellia, Glyptoactis.

2. Venericardia.

3. Venericardia, Kellia, Bornia.

4. Venericardia, Thecodonta, Neaeromya, Cardita.

5. Venericardia, Glans, Miodontiscus.

6. Venericardia.

7. Cardita, Cyclocardia, Mysella, Glans, Glyptoactis, Cyclocardia.

8. Venericardia, Glyptoactis.

9. Cyclocardia, Venericardia, Basterotia, Cardita, Milneria.

Figure 1. Divisions used in California for geographic range of species of pelecypods, Erycinidae through Carditidae

2. Divisions used in Baja California peninsula for geographic range of species of pelecypods, Erycinidae through Carditidae

3. Preliminary phylogenetic chart of Glyptoactis and Venericardia in the eastern Pacific prepared by LouElla Saul, Los Angeles County Museum of Natural History.

\section{TABLES}

TABLES 1-3. Geologic and geographic distribution in the eastern Pacific region of the genera:

1. Lasaea, Kellia, Aligena, Bornia, Mysella, Thecodonta, Neaeromya, Basterotia, Cardita, and Strophocardia ---.---

2. Cyclocardia, Glans, and Miodontiscus --

3. Venericardia, Glyptoactis, and Milneria 


\title{
TERTIARY MARINE PELECYPODS OF CALIFORNIA AND BAJA CALIFORNIA: ERYCINIDAE THROUGH CARDITIDAE
}

\author{
By Ellen JAMES MOORE
}

\begin{abstract}
The description of the mollusks in the Tertiary formations of California and Baja California is continued from Chapter D. Forty-eight species in the families Erycinidae, Kelliidae, Montacutidae, Sportellidae, and Carditidae, representing 15 genera, are covered in this chapter. Of the 15 included genera, 1 occurs in the Cretaceous, 2 in the Paleocene, 3 in the Eocene, 1 in the Oligocene, 3 in the Miocene, 11 in the Pliocene, 5 in the Pleistocene, and 12 in the Holocene of the included geographic area. Four genera are extinct or locally extinct.

Venericardia (Pacificor) taliaferroi Verastegui was found by Verastegui (1953) to occur in the Late Cretaceous lower part of the Dip Creek Formation of Taliafero (1944) of Late Cretaceous and Paleocene age, thus extending the range of the genus Venericardia and the subgenus Pacificor into the Late Cretaceous in the eastern Pacific.
\end{abstract}

\section{INTRODUCTION}

\section{PURPOSE AND SCOPE}

The description and illustration of the Tertiary marine mollusks of California and Baja California started in Chapter $\mathrm{A}$ is continued in this chapter, which treats the families Erycinidae, Kelliidae, Montacutidae, Sportellidae, and Carditidae.

A total of 48 species assigned to the included families occur in the geographic study area. For convenience of reference, the figures showing the geographic divisions used for the Californias are reproduced here (figs. 1,2 ).

\section{PROCEDURE}

All Tertiary marine mollusks originally described from California and the Baja California peninsula, and all species originally described from other

Manuscript approved for publication, September 24, 1991. geographic localities but known to occur in the Tertiary of the Californias, are included in this study. All positively identified species that have been found on faunal lists are also included. Only in genera that are extremely rare have I included species that are questionably identified.

In this work, the species are arranged systematically following the order of families, genera, and subgenera given in the Treatise (Moore, 1969). Within the systematic groups, species are arranged by geologic age, beginning with the oldest species and ending with the youngest.

Brief synopses of generic and subgeneric characters are given in the appropriate places; more complete synopses will be found in the Treatise (Moore, 1969), in Keen (1971), and in Olsson (1961).

Distribution tables are included to show graphically the geographic and geologic distribution of species within each family. To facilitate finding a specific taxon, the species are listed alphabetically under genus and subgenus in the tables.

The synonymy for each species includes the original citation and subsequent substantive references. The accuracy of identifications cited in subsequent references in the synonymy has not been verified.

The type is usually that of the author of the original description or of later workers who selected a lectotype or neotype. If the original locality description is so vague that it is of little use, the type locality is described as corrected or modified by other workers such as Keen and Bentson (1944) and the modifications given within brackets. All other localities are cited as originally described except the formation name given is that of the one currently being used.

Previously published supplementary descriptions and comparisons are included, and I have supplemented them in the section headed "Comments." For most descriptions, my comments are based only on examination of primary type material. 
E2

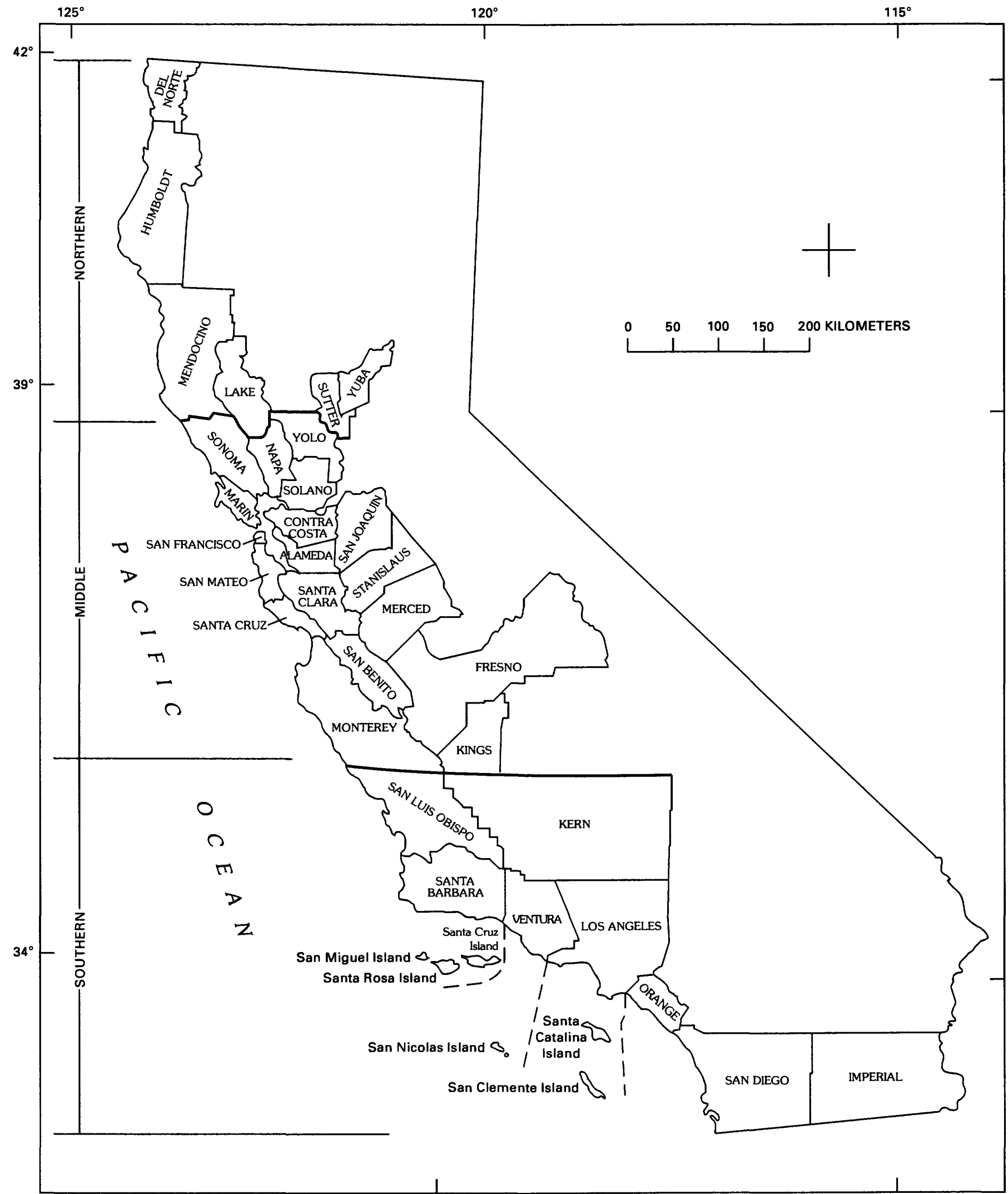

Figure 1.-Divisions used in California for geographic ranges of species of pelecypods, Erycinidae through Carditidae. 


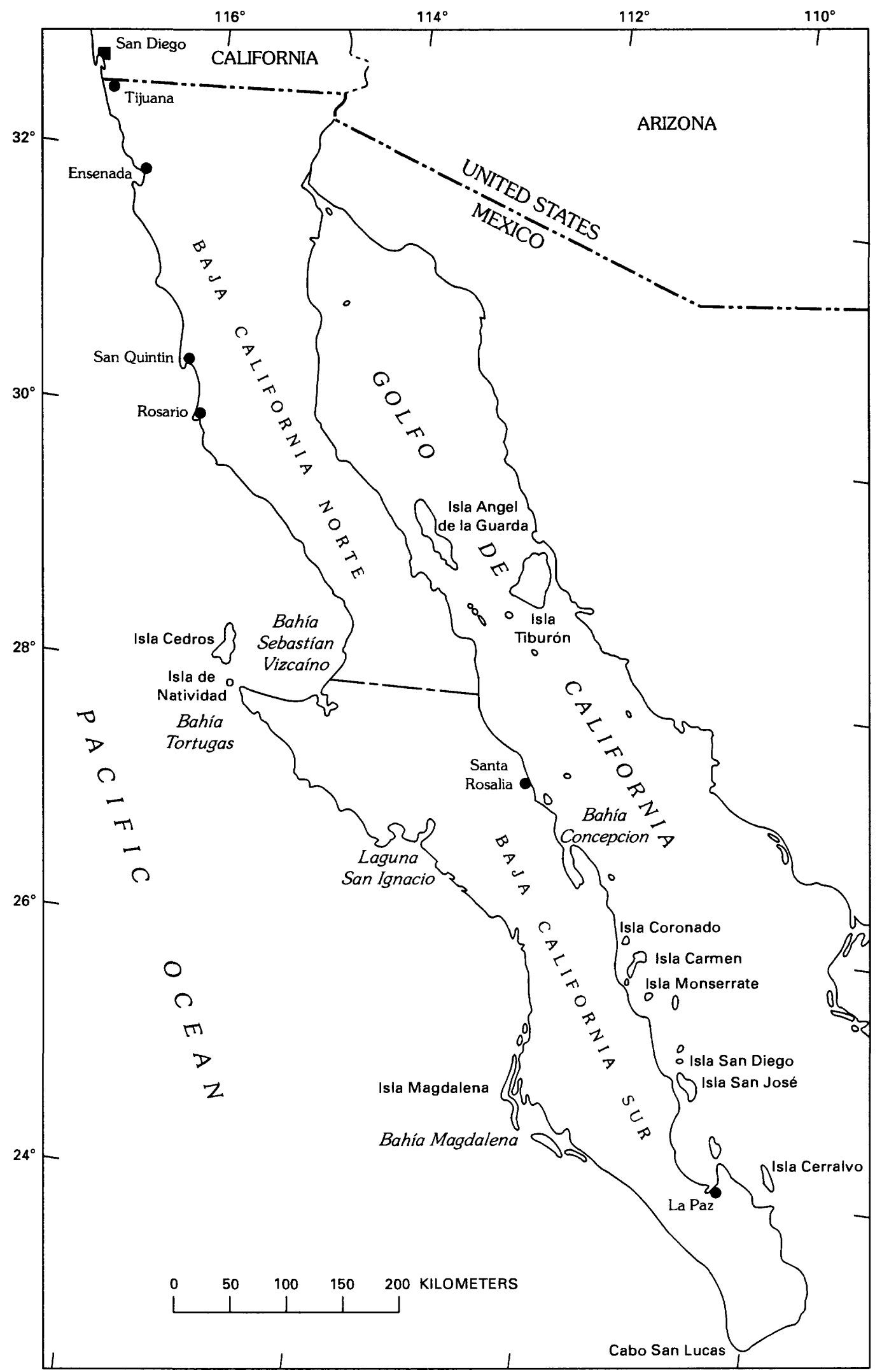

Figure 2.-Divisions used on Baja California Peninsula for geographic ranges of species of pelecypods, Erycinidae through Carditidae. 
All available published data for each species have been included in the section on geographic and geologic age range, including that contained in faunal lists when the identification is unqualified. Age ranges have not been refined within epochs. Where a stage name the same as a formation name is used (see fig. 3), it is placed in quotes to distinguish it from the rock unit.

The divisions used here to indicate the approximate geographic range of species within California based on county distribution are northern, middle, and southern (fig. 1); the divisions for the Baja California Peninsula, norte and sur (fig. 2) (tables 1-3).

An attempt has been made to include all citations to a species that are unqualified and every geologic formation in which it is reported to occur in the Californias. The assumption has been made that all identifications of species are correct unless there is strong evidence to the contrary. Under "Occurrence," the author cited for a formation is the individual who named or cited the species and not the author who mapped or named the formation. The stratigraphic nomenclature used herein is that of the author(s) cited and does not necessarily agree with that of the U.S. Geological Survey. The ages given for the stratigraphic units follow the classification of geologic time currently used by the U.S. Geological Survey (See "Geologic Formations Cited for Occurrence of Pelecypods" at end of paper), which does not necessarily agree with the the most recent revisions by workers outside the Survey. Each formation listed is followed by the name of the author and date of publication of the work from which it was obtained. More than one reference to a formation is given where it might be useful to the reader. The list of formations given for species occurrence should not be considered complete nor necessarily accurate. Many western American Tertiary faunas have not been included in a monograph, therefore, their species content is not fully known. It is hoped that the list of formational occurrences reported will serve as a framework upon which the true distribution of each species can be built.

The type specimens were all photographed by Charles L. Powell, II, of the U.S. Geological Survey. Owing to the fact that the specimens photographed were borrowed from other institutions, the usual technique of opaquing specimens for photography (Sakamoto, 1973) was not used. The holotype of each Tertiary species is figured if the type is extant. Holocene type specimens have generally not been figured; specimens considered to be of the same species by authors such as Durham (1950) and Hertlein and
Grant (1972) are used for these illustrations, and this information is included in the plate explanation.

Most of the data on habitat has been compiled from Abbott (1974), Bernard (1983), Hertlein and Grant (1972), Keen (1971), Morris and others (1980), Smith and Gordon (1948), Stanley (1970), and Yonge and Thompson (1976).

\section{ACKNOWLEDGMENTS}

John G. Vedder, of the U.S. Geological Survey, reviewed the stratigraphic occurrences of species, and his pertinent suggestions were most helpful. LouElla Saul, Los Angeles County Museum of Natural History, reviewed the section on Venericardia, and Eugene Coan, Palo Alto, Calif., reviewed the section on Cardita and Cyclocardia; I am grateful for their generous assistance. LouElla Saul also generously allowed me to publish her preliminary phylogenetic chart of Glyptoactis and Venericardia, and I am indebted to her for this kindness.

The following individuals made available or loaned type material, and I am indebted to them: Elana Benamy, Academy of Natural Sciences of Philadelphia, Frederick J. Collier and Jann W.M. Thompson, National Museum of Natural History, Thomas A. Deméré, San Diego Natural History Museum, David R. Lindberg, University of California Museum of Paleontology, Robert Van Syoc, California Acadamy of Sciences, and Edward C. Wilson, Los Angeles County Museum of Natural History.

The late Mildred P. James made up cards for each species and its occurrences as noted on faunal lists. This was a time consuming task that she performed as a volunteer, and I am grateful to her for her patience and support.

\section{ABBREVIATIONS}

ANSP: The Academy of Natural Sciences of Philadelphia, Pennyslvania.

BM(NH): British Museum of Natural History, London, England.

CAS: California Academy of Sciences, San Francisco, Calif.

CASG: California Academy of Sciences Geology, San Francisco, Calif.

LACMP: Los Angeles County Museum of Paleontology, California.

LAM: Los Angeles County Museum of Natural History, California.

MCZ: Harvard Museum of Comparative Zoology, Cambridge, Mass. 
TABle 1.-Geologic and geographic distribution of the genera Lasaea, Kellia, Aligena, Bornia, Mysella, Thecodonta, Neaeromya, Basterotia, Cardita, and Strophocardia in the eastern Pacific Region

$[\mathrm{H}=$ Holocene; Ple=Pleistocene; Pl=Pliocene; $\mathrm{M}=$ Miocene; $\mathrm{E}=$ Eocene; $\mathrm{Pa}=$ Paleocene $]$

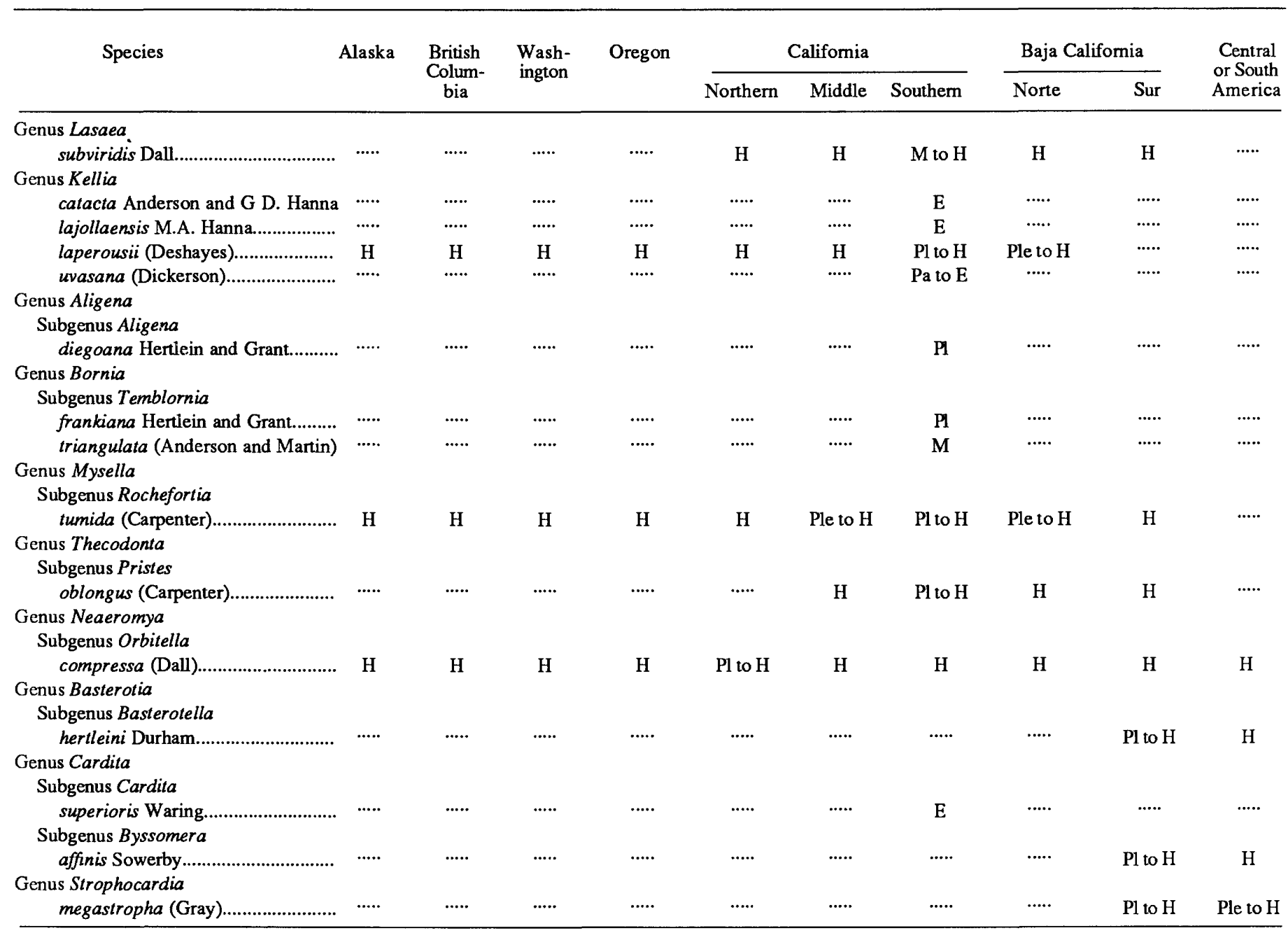

CAS/SU: Stanford University, Stanford, Calif. [Stanford University collections are now in the California Academy of Sciences]

SU: Stanford University, Stanford, Calif.

UC: University of California, Berkeley.

UCMP: University of California, Museum of Paleontology, Berkeley.

UCLA/LACMP: University of California at Los Angeles. [University of California at Los Angeles type collections are now in the Los Angeles County Museum of Paleontology]

UCR: University of California at Riverside.

USGS: U.S. Geological Survey, Washington, D.C., Cenozoic locality register.

USGS M: U.S. Geological Survey, Menlo Park, Calif., Cenozoic locality register.
USNM: National Museum of Natural History, Washington, D.C.

UW: University of Washington, Seattle.

\section{SYSTEMATICS: PELECYPODS-CONTINUED FROM CHAPTER D}

\section{Family ERYCINIDAE \\ Genus LASAEA Brown, 1927}

Transversely rounded, minute, inflated, inequilateral, smooth, anterior side longest, beaks straight.

Geographic range.-Worldwide.

Geologic range.-Eocene to Holocene (table 1).

Habitat.-Intertidal, especially among Mytilus (Keen, 1971); intertidal to $10 \mathrm{~m}$ in the eastern Pacific (Bernard, 1983). 


\author{
Lasaea subviridis Dall, 1899 \\ Plate 1, figures 2, 4
}

Lasaea rubra subviridis Dall, 1899, p. 881 [ex Carpenter MS]. Lasaea subviridis Dall, 1899. Keen, 1938, p. 29-30, pl. 2, figs. 1-6. Keen, 1971, p. 137, fig. 311.

Original description.-“ $[L$. rubra $]$ variety subviridis Carpenter, is pale greenish yellow. It is reported from Lower California."

Neotype.-CAS/SU 6053; CASG 65100 (Keen, 1938); syntypes USNM 75032. Coan (1977) believed the neotype designation of Keen (1938) to be invalid because Dall's material was never properly searched.

Type locality.- "Lower California" (Dall, 1899); Isla San Martin, Baja California Norte (Keen, 1938); Bahía San Quintin, Baja California Norte (Coan, 1987). Holocene.

Supplementary description.--"Shell minute, inequilateral (anterior end longer), oblique, rather flat, greatest dimension parallel to postero-dorsal margin, but not parallel to a line joining muscle-scars, beaks at posterior $2 / 5$, umbones low (usually less than 1/10 the height of the shell); junction of anterior and ventral margins somewhat attenuated, ventral margin rounded, joining posterior in a smooth curve; colour greenish or yellowish grey, suffused with pink at the beaks, the colour sometimes extending down into the ventral half of the shell, hinge tinged with pink; surface sculptured by irregular growth-constrictions and minute, wavy concentric striae, especially near the ventral margins; hinge of right valve with a lamellar (sometimes bifid) anterior lateral and nymph, a deep cardinal pit, and a lamellar posterior cardinal above the long, oblique resilium, hinge of left valve with two lamellar anterior laterals receiving the single lateral of the right valve, a thorn-like cardinal, and a small lamellar posterior lateral." (Keen, 1938)

Comparison.-"Lasaea subviridis is distinguished from $L$. rubra by its greater size and the presence in the adult of wavy concentric sculpture, from Western Pacific species such as purpurata and scalaris by the wrinkling rather than pitting of the sculpture, and from $L$. cistula by its more oblique outline, its light colour, less tumid and lower umbones, and by the smooth slope of the anterior margin downward from the beaks. In dimensions, young specimens***are consistently longer than cistula of the same height; the height-length ratio of young subviridis is very similar to that of adult $L$. rubra." (Keen, 1938)

Geographic range.-Living: Northern California to Baja California Sur; fossil: southern California.

Geologic range.-Miocene and Pliocene.

Occurrence in California.-Miocene and Pliocene: Capistrano Formation (Kern and Wicander, 1974).

Habitat.-Among the byssi of Mytilus along the uppermost edge of the mussel colonies (Keen, 1936); in kelp holdfasts (Smith and Gordon, 1948); intertidal to $10 \mathrm{~m}$ (Bernard, 1983).

\section{Family KELLIIDAE Genus KELLIA Turton, 1822}

Ovate, slightly angular and strongly convex, with concentric striation.

Geographic range.-Worldwide.

Geologic range.-Eocene to Holocene (table 1).

Habitat.-Intertidal to $50 \mathrm{~m}$ in the eastern Pacific (Bernard, 1983); often nestles in holes in rock (Hertlein and Grant, 1972).

\section{Kellia catacta Anderson and GD. Hanna Plate 1, figure 7}

Corbula harrisi Dickerson, 1915, p. 42, 56, pl. 4, fig. 6 . Dickerson, 1916, p. 420, 445.

Kellia catacta Anderson and GD. Hanna, 1925, p. 171, pl. 2, fig. 6. New name for Corbula harrisi Dickerson not Corbula (Cuneocorbula) swiftiana harrisi Dall, 1898.

Original description.--"Shell small, thick, subtrigonal, with beak central, slightly prosogyrate; anterior dorsal slope slightly steeper than the moderately steep posterior dorsal slope; base broadly rounded; posterior end sharply rounded; a faint umbonal slope extending to the point between the posterior end and the base; shell decorated by faint radial ribbing which is strongest at posterior end along the umbonal slope and by concentric growth lines. Interior of shell is unknown and hence generic reference is doubtful. This species is not so thick as C. parilis Gabb and its concentric ribbing is not so strong."

Holotype.-CAS 275.

Type locality.-CAS 244. Kern County, Calif. Tejon Formation, Eocene.

Geographic range.-Southern California.

Geologic range.-Eocene (table 1 ).

Occurrence in California.-Eocene: Tejon Formation (Dickerson, 1915).

\section{Kellia uvasana (Dickerson) Plate 3, figures 9, 12}

Corbula uvasana Dickerson, 1915, p. 42, 46, pl. 4, fig. 7. Dickerson, 1916, p. 420, 445.

Kellia uvasana (Dickerson). Anderson and GD. Hanna, 1925, p. 172 , pl. 2, fig. 7; pl. 9, fig. 11 .

Original description.-"Shell small, inflated with central beak, anterior dorsal margins slightly concave with moderate slope to a subtruncate anterior end; posterior dorsal margin with slight slope to a broadly rounded posterior; ventral margin broadly rounded. Faint radial lines and feeble concentric growth lines decorate this shell. Interior unknown.

"Dimensions:-Length, $7 \mathrm{~mm}$; height, $5 \mathrm{~mm}$; convexity, 2 mm."

Holotype.-CAS 276; CASG 244.04.

Type locality.-CAS 244. Kern County, Calif. Tejon Formation, Eocene.

Supplementary description.-"The shell is small, thin, elliptical; surface smooth, except for small radial ridges extending from the umbones to the margins near the anterior and posterior ends, forming small marginal denticulations within." (Anderson and Hanna, 1925, p. 172)

Geographic range.-Southern California.

Geologic range.- Paleocene to Eocene (table 1).

Occurrence in California.-Paleocene: Cerros Shale Member of Lodo Formation (Dickerson, 1916); Eocene: Tejon Formation (Dickerson, 1915).

\section{Kellia lajollaensis M.A. Hanna Plate 3, figure 8}

Kellia lajollaensis M.A. Hanna, 1927, p. 284, pl. 37, fig. 7.

Original description.-"Shell small, well inflated, subquadrate; ventral margin straight; posterior margin rounded to slightly truncated; anterior margin rounded; beak prominent, rounded, 
nearly central; dorsal slopes on either side of the beak straight; surface ornamented on the posterior and anterior by rather prominent well-rounded ribs which are separated by concave interspaces of less width; concentric ornamentation consists of wide flat-topped ridges marked off by narrow lines; these concentric ridges distinctly overlap each other with the overlap toward the margin and not toward the beak; this overlap shows very well where the concentric ridges cross the radial ones, the concentric lines bend toward the beak in crossing the radial ridges; no radial sculpturing present in the central portion of the shell; interior of the type not seen. Dimensions: Altitude $4.5 \mathrm{~mm}$., length $6.5 \mathrm{~mm}$., dorsal angle 117 degrees."

Holotype.-UCMP 31036.

Type locality.-UC 3991. San Diego County, Calif. Rose Canyon Shale of Hanna (1927), Eocene.

Comparison.-_Kellia lajollaensis***most closely resembles Kellia catacta Anderson and Hanna, described by Dickerson as Corbula harrisi. However, Kellia lajollaensis has a different shape. The dorsal angle is greater and the ventral margin is straight. The new species differs much in sculpturing from either Kellia catacta or Kellia uvasana (Dickerson). The radial ridges on either extremity are more prominent, and the concentric sculpturing is different." (Hanna, 1927)

Geographic range.-Southern California.

Geologic range.-Eocene.

Occurrence in California.-Eocene: Rose Canyon Shale (M.A. Hanna, 1927).

\section{Kellia laperousii (Deshayes) Plate 3, figures 10, 15}

Chironia laperousii Deshayes, 1839, p. 357.

Kellia laperousii (Deshayes). Arnold, 1903, p. 137, pl. 18, figs. 1, 1a. Oldroyd, 1924, p. 131, pl. 10, fig. 2; pl. 33, fig. 4. Yonge, 1951 , p. $451-453$, text fig. 1 . Hertlein and Grant, 1972, p. 237, pl. 44, figs. 11, 19.

Chironia suborbicularis (Montagu) variety laperousii Deshayes. Grant and Gale, 1931, p. 300, pl. 14, figs. 19a, 19b.

Original description.- "Testa ovato transversa, subequilaterali, inflato turgida, laevigata; alba sub-epidermide viridi lutescente, umbonibus minimis, acutis, oppositis."

Holotype.-In the collection of the Laboratoire de Malacologie, Musée National d'Histoire Naturelle, Paris? (Hertlein and Grant, 1972, p. 237)

Type locality.-No locality cited originally.

Comparison.- "Some of the small valves, about $3 \mathrm{~mm}$ long, from near the Mexican boundary, bear a close resemblance to $K$. suborbicularis Montagu, originally described from England. However, there is so much variation in shape in a series of Recent specimens of $K$. laperousii, some elongated, some subcircular, that we assign all the fossil valves in the present collections to that species.

"The question as to whether this species is cosmopolitan or whether several closely related forms are involved has been discussed by several authors. E.A. Smith [1902, p. 163] stated that shells of this species could not be separated with certainty from allied forms. More recently Soot-Ryen [1951, p. 31], in a discussion of Antarctic shells similar to $K$. suborbicularis, stated that the relationship of such forms is still unsettled but he suggested that probably a number of nearly related species are concerned in this problem.

"None of the fossils from the San Diego Formation is as circular in outline as the syntypes of the Recent west American $K$. laperousii chironi Carpenter illustrated by Palmer (1958, pl. 9, figs. 6-10\}.

"Kellia rotunda Carpenter was described as much larger than $K$. suborbicularis and nearly round in outline." (Hertlein and Grant, 1972, p. 237)

Geographic range.-Living: Bering Sea and Pribilof Islands to Isla Tiburon, Golfo de California; fossil: southern California and Baja California Norte.

Geologic range.-Pliocene to Holocene (table 1).

Occurrence in California.-Pliocene: Cebada Member, Careaga Sandstone (Woodring and Bramlette, 1950) and San Diego (Hertlein and Grant, 1972) Formation; Pliocene and Pleistocene: San Pedro Formation (Arnold, 1903); Pleistocene: unnamed strata near Los Angeles (Valentine, 1956; Kanakoff and Emerson, 1959), San Pedro Formation (Arnold, 1903), Newport Bay, and in San Diego (Arnold, 1903) and Baja California Norte (Valentine and Roland, 1969).

Habitat.-Intertidally to $395 \mathrm{~m}$ (Hertlein and Grant, 1972); intertidally to $20 \mathrm{~m}$ in the eastern Pacific (Bernard, 1983).

\section{Genus ALIGENA Lea, 1843}

Shell small, valves somewhat trigonal with the anterior end longer. Hinge plate very narrow, usually with a fingerlike tooth below the umbo in each valve, right-valve tooth slightly larger than the left, and a long oblique socket for the resilium ending in a widening of the hinge plate that simulates a posterior lateral tooth.

Geographic range.-Europe, Africa, North America.

Geologic range.-Miocene to Holocene.

Habitat.-In temperate and tropical waters, intertidally to $112 \mathrm{~m}$ (Hertlein and Grant, 1972); intertidally to $25 \mathrm{~m}$ in the eastern Pacific (Bernard, 1983). Inhabits relatively deep holes in rock made by borers, or empty shells such as mytilids, and is usually byssally attached (Yonge, 1951).

\section{Subgenus ALIGENA}

Subvertically pointed right cardinal tooth.

\section{Aligena (Aligena) diegoana Hertlein and Grant Plate 1, figures 6, 8-10, 12, 13}

Aligena diegoana Hertlein and Grant, 1972, p. 235-236, pl. 44, figs. 1,6 ; pl. 45 , figs. $6,7,10,11,13$.

Original description.- "Shell roundly quadrangular, rather large for the genus, convex, the anterior is longer and narrower than the posterior end; beaks small, prosogyrate, situated a little posterior to the middle of the valves; lunular area gently depressed; anterior dorsal margin sloping moderately steeply to the anterior end which is rounded and slightly attenuated, posterior dorsal margin sloping gently downward and merging imperceptibly into the broadly rounded posterior end, ventral margin very slightly rounded; exterior of valves sculptured only with lines of growth; hinge of right valve with a large, slightly twisted tooth beneath the beak, behind this a subtriangular, elongated ligamental pit; in front of the tooth there is an elongated depression which receives a projection of the opposite valve and fades out as a slight groove along the margin; hinge of left valve (paratype) with a large, tooth-like projection of the 
lunular margin, behind this a very small cardinal lamella (lacking on some specimens) below the beak, and back of this the ligamental pit. Dimensions of holotype, a right valve, length $7.9 \mathrm{~mm}$, height $6.1 \mathrm{~mm}$, convexity (one valve), (approximately) $2 \mathrm{~mm}$.)"

Holotype.-LACMP 4547.

Type locality.-LAM 305. San Diego County, Calif. San Diego Formation, Pliocene.

Supplementary description.- "This species is represented in the present collections by more than 30 single valves. These vary in outline, some are more rounded in outline than others, and in some specimens the ventral margin is nearly straight. A broad, low, medial sulcus is present on some valves.

"The cardinal tooth in the left valve of $A$. diegoana***is reduced to a thin lamella, or is absent on some specimens. The development of a tooth-like projection of the lunular margin which fits into a groove on the opposite valve appears to be compensatory for the reduction of the cardinal and augments the interlocking of the hinge area." (Hertlein and Grant, 1972, p. 236)

Comparison.- "The general outline of Aligena diegoana***is somewhat similar to that shown in an illustration of a Recent specimen from off the west coast of Lower California which Harry (1969, fig. 16) referred to Aligena cerritensis Arnold. The type specimen of $A$. cerritensis is obliquely ovoid in outline.

"The general shape of some valves of the new species is similar to that of Aligena aequata var. nuca Dall from Miocene strata in Maryland***. The new species also bears a resemblance to the east American Aligena laevis H. C. Lea which occurs in strata of Miocene and Pliocene age. The west American species is more quadrate in outline and the hinge of the right valve apparently has a deeper, more trigonal ligamental pit." (Hertlein and Grant, 1972)

Geographic range.-Southern California.

Geologic range.-Pliocene.

Occurrence in California.-Pliocene: San Diego Formation (Hertlein and Grant, 1972).

\section{Genus BORNIA Philippi, 1836}

Transversely trigonal to trapezoidal, slightly inequilateral, flattened; surface smooth, polished, or faintly ribbed and striated. Ligament comprising a feeble external part, internal resilium without a lithodesma. Left-valve hinge with long, strong, posterior lateral tooth and a smaller, less distant anterior lateral together with a small cardinal closely adjacent to it; right valve with strong lateral sockets and a small anterior cardinal socket.

The shell of Bornia differs from that of Kellia in that the surface is radially striate or punctate, at least in part, lacks a periostracum, and has a narrower hinge with the posterior cardinal of the left valve greatly reduced in size.

Geographic range.-Worldwide.

Geologic range.-Paleocene to Holocene.

\section{Subgenus TEMBLORNIA Keen, 1943}

Short cardinals and shallow small resilium, so that posterior laterals, just behind it, look like cardinals; hinge plate straight under resilium.

Resembling Bornia in outline, with radial sculpture on anterior and posterior slopes; differing from Bornia in the structure of the hinge; resilifer small and shallow, ventral margin of hinge plate entire, not bisected as in Bornia by the insertion of the resilium.

Compared to Semeloidea, the lower margin of the hinge plate of Temblornia is more arched, the posterior cardinal is less curved and the radial riblets, externally, are more numerous and finer.

Geographic range.-North America, South America.

Geologic range.-Eocene to Pliocene.

\section{Bornia (Temblornia) triangulata (Anderson and Martin)} Plate 3, figures 17, 18

Donax triangulata Anderson and Martin, 1914, p. 41, pl. 3, fig. 9.

Bornia (Temblornia) triangulata (Anderson and Martin). Keen, 1943 , p. 39, pl. 3, figs. 6,7 .

Original description.-- "Valves small, thin, trigonal, convex; beaks a little anterior to the middle; dorsal margins nearly straight; anterior extremity rounded; basal margin nearly straight; posterior end sharply rounded; an umbonal angulation extending from the beaks to the anterior and posterior extremities, forming areas sculptured with six or seven radial ribs; left valve with one cardinal and two lateral teeth; ends crenulated within; muscular impressions indistinct."

Holotype.-CAS 130; CASG 65.02.

Type locality.-CAS 65. Kern County, Calif. Round Mountain Silt, Miocene.

Supplementary description.- -The shell is of shining porcellaneous texture with six to eight faintly incised grooves at the anterior and posterior ends. The grooves crenulate the inner margin slightly." (Keen, 1943, p. 39)

Geographic range.-Southern California.

Geologic range.-Miocene.

Occurrence in California.-Miocene: Round Mountain Silt (Keen, 1943).

\section{Bornia (Temblornia) frankiana Hertlein and Grant Plate 3, figures 13, 14}

Bornia (Temblornia) frankiana Hertlein and Grant, 1972, p. 238239, text fig. 11.

Original description.--"Shell, a right valve, small, elongately trigonal, moderately inflated, nearly equilateral, slightly longer posteriorly; anterior and posterior margins nearly straight, near the ends rounding into the ventral margin; 10 rounded radial ribs on the anterior end just posterior to the margin and 7 similar ones, somewhat flattened, on the posterior end, the ribs are faint dorsally but become gradually more strongly developed toward the ventral margin; ribs separated by interspaces which are a little wider than the ribs and in these, toward the ventral margin, lines of growth are accentuated (perhaps a result of erosion); remainder of the valve smooth except for somewhat irregular lines of growth; hinge with 2 well developed cardinal teeth; interior of anterior and posterior ends of valve crenulated and slightly denticulated corresponding to the exterior sculpture. Length $6.5 \mathrm{~mm}$, height $4.1 \mathrm{~mm}$."

Holotype.-LACMP 4624.

Type locality.-LAM 305c. San Diego County, Calif. San Diego Formation, Pliocene.

Comparison.- "Bornia (Temblornia) frankiana***differs from the two other described species of Temblornia in its more 
elongately trigonal outline and in the nearly straight anterior and posterior margins." (Hertlein and Grant, 1972, p. 239)

Geographic range.-Southern California.

Geologic range.-Pliocene.

Occurrence in California.-Pliocene: San Diego Formation (Hertlein and Grant,1972).

\section{Family MONTACUTIDAE Genus MYSELLA Angas, 1877}

Shell triangularly ovate, anterior end longer, sculpture concentric; left valve with a large, diverging, flattened tooth posterior to the triangular resilifer; anterior margin of resilifer thickened and margined to simulate a transverse tooth; in front of this is a small socket; right valve with hinge margin on each side of umbo produced, which is overlapped by the hinge line of the opposite valve; the posterior toothlike edge interlocks above the cardinal tooth of the left valve and, the anterior which is shorter, is received in the socket in front to the ridgelike edge of resilifer. These toothlike margins of the right valve represent cardinal rather than lateral teeth.

Geographic range.-Worldwide.

Geologic range.-Miocene to Holocene.

Habitat.-2 to $97 \mathrm{~m}$ in the eastern Pacific (Bernard, 1983).

\section{Subgenus ROCHEFORTIA Velain, 1877}

Shell more or less rounded at both ends. Resilium with crests as bifid tooth. Differs from Mysella in having a stouter, shorter chondrophore with minute crest at its top on right valve and in having crests on the resilium.

Geographic range.-Indian Ocean, Australia, North America.

Geologic range.-Pliocene to Holocene.

Habitat. -5 to $120 \mathrm{~m}$ in the eastern Pacific (Bernard, 1983).

\section{Mysella (Rochefortia) tumida (Carpenter)}

Plate 7, figures 5, 6

Tellimya tumida Carpenter, 1864, p. 602, 611, 643.

Mysella tumida (Carpenter). Dall, 1899, p. 881, 892, pl. 87, fig. 7. Palmer, 1958, p. 88, pl. 7, figs. 8-12. Abbott, 1974, p. 473, fig. 5447.

Mysella tumida Carpenter. Hertlein and Grant, 1972, p. 239. 240, pl. 44, figs. 2-5, 7, 8, 12 .

Mysella cf. M. tumida (Carpenter). Addicott, 1966, p. C4, pl. 4, figs. 12, 13.

Original description.--Between [Mysella] bidentata and substriata: ossicle minute."

Holotype.-USNM 5242.

Type locality.-Puget Sound, Kennerley, Wash. (Palmer, 1958). Holocene.

Supplementary description.- “***moderately compressed, somewhat triangular in shape. The tiny beaks are almost at the posterior end. The hinge teeth are large in comparison with other species." (Abbott, 1974, p. 473)

Comparison.- "The species described by Dall as Mysella pedroana is elongate in outline but the hinge was described as 'feeble'. The illustration of the type shows the hinge to be quite different from that of $M$. tumida." (Hertlein and Grant, 1972 , p. 240)
Geographic range.-Living: Shumagin Islands, Alaska, to Laguna Scammon, Baja California Sur; fossil: middle California to Baja California Norte.

Geologic range.-Pliocene to Holocene.

Occurrence in California: Pliocene: Graciosa Member, Careaga Sandstone (Woodring and Bramlette, 1950) and San Diego Formation (Hertlein and Grant, 1972); Pleistocene: unnamed strata at Point Año Nuevo, San Mateo County, Calif. (Addicott, 1966) and at Bahía San Quintin, Baja California Norte (Hertlein and Grant, 1972).

\section{Genus THECODONTA A. Adams, 1864}

Transversely rounded, convex, very inequilateral, posterior part much elongated. Sculpture concentric. Anterior left lateral curved, gradually increasing subparallel to margin, then straightened along oblique resilium. Posterior laterals remote, thickened.

\section{Subgenus PRISTES Carpenter, 1864}

More transverse than oblique, with scarcely projecting beaks and arcuate anterior, transversely serrated laterals; duplicate subparallel left posteriors.

Geographic range.-California.

Geologic range.-Pliocene to Holocene.

\section{Thecodonta (Pristes) oblongus (Carpenter) Plate 4, figures 3, 4}

Pristes oblongus Carpenter, 1864, p. 611, 643. Palmer, 1958, p. 89 , pl. 9 , figs. $11-13$. Hertlein and Grant, 1972 , p. 240 241 , pl. 44, figs. 9, 10, 13, 14 .

Original description.- "Like Tellimya, with long marginal teeth, serrated near hinge."

Lectotype.-USNM 15592 (Palmer, 1958).

Type locality.-San Pedro, Calif. (Palmer, 1958). Holocene.

Supplementary description.-" 3 to $5 \mathrm{~mm}$., quadrate, resembling a Nucula in shape, with the umbones at the anterior truncated end. Dorsal margin arching, below it one of the long cardinal teeth is serrated. Posterior end somewhat pointed. Lunule small and concave." (Abbott, 1974)

Geographic range.-Living: Monterey, Calif. to Baja California Sur; fossil: Southern California.

Geologic range.-Pliocene to Holocene.

Occurrence in California.-Pliocene: San Diego Formation (Hertlein and Grant, 1972); Pleistocene: Unnamed strata at Crown Point, San Diego (Valentine (1959).

Habitat.-Occasionally found living commensally under the girdle of the chiton Stenoplax conspicua (Pilsbry). (Morris and others, 1980)

\section{Genus NEAEROMYA Gabb, 1873}

Transversely subquadrangular to trigonal, finely striated. Right strong anterior laminar tooth and oblique posterior enlarged margin; oblique resilium between them; left thinner oblique anterior. 
Geographic range.-Central America, North America, Europe. Geologic range.-Pliocene to Holocene.

\section{Subgenus ORBITELLA Dall, 1900}

Anterior margin broadly rounded, elongate, thus very inequilateral.

Geographic range.-United States: Florida and Alaska to Mexico.

Geologic range.-Miocene to Holocene.

Habitat. -0 to $50 \mathrm{~m}$ in the eastern Pacific (Keen and Coan, 1974).

\section{Neaeromya (Orbitella) compressa (Dall) Plate 4, figures 5, 7}

Erycina (Pseudopythina) compressa Dall, 1899, p. 888, pl. 87, figs. 1, 8.

Pseudopythina compressa (Dall). McGinitie, 1959, p. 173, pl. 19, figs. 2, 3, 5 .

“Orbitella"compressa (Dall). Roth, 1979, p. 293-294, pl. 3, figs. $6,7$.

Original description.- "Shell large, subquadrate, thin, moderately compressed, white, covered with a conspicuous, thin, wrinkled, partly glossy periostracum; nearly equilateral, the posterior end slightly broader, both ends rounded, the basal margin nearly straight; beaks inconspicuous, surface with strong, irregular incremental lines, but no radial sculpture; pallial scar rather wide and irregular, merging into the subequal, rather narrow adductor scars; resilium large, wide, and long, more or less calcareous ventrally, left valve with one obscure cardinal tooth, right valve with the tooth better developed; the right dorsal valve margins overlap those of the left valve a little, but there are no distinct lamella. Lon. 18, alt. 13, diam. $6 \mathrm{~mm}$."

Holotype.-USNM 107855.

Type locality.--Dredged on muddy bottom in from 2 to 28 fathoms in the eastern part of Bering Sea, south of Nunivak Island, the eastern Aleutians, and southward to Sitka, Alaska."

Supplementary description.- "Keen and Coan (1974) and F.R. Bernard (pers. comm.) suggest that the customary assignment of this species to Pseudopythina Fischer, 1878, is open to question. The hinge characters are approximately those of Orbitella, but the shell is unusually large for that genus. Among west American bivalves, the most closely related species seems to be 'Pseudopythina'rugifera (Carpenter, 1864), which in turn may have affinities to the genus Pythinella Dall, 1899, of the North American east coast and the west American tropics." (Roth, 1979, p. 294)

Geographic range.-Living: Alaska to Mexico; fossil; northern California.

Geologic range.-Pliocene to Holocene.

Occurrence in California.-Pliocene: Lower part of the Rio Dell Formation (Roth, 1979).

Habitat. -0 to $50 \mathrm{~m}$ (Keen and Coan, 1974); 7 to $90 \mathrm{~m}$ on crustaceans (Abbott, 1974).

\section{Family SPORTELLIDAE Genus BASTEROTIA Mayr in Hornes, 1859}

Shell small, subquadrate corbuliform, with a sharp carination running from the beak posteriorly. Valves convex, usually solid, the beaks prosogyrate. Surface marked with fine concentric lines of growth and a sprinkling of fine or coarse granules. Ligament external, attached to a short, stout, plate-like nymph. Hinge with large, hook-shaped cardinal tooth in each valve, bordered behind or in front by a deep socket; the socket lies in front of the tooth in right valve and behind it in left. No pallial sinus.

Geographic range.-Worldwide.

Geologic range.-Miocene to Holocene.

Habitat.-10 to $1,170 \mathrm{~m}$ (Hertlein and Grant, 1972); intertidally to $45 \mathrm{~m}$ in the eastern Pacific (Bernard, 1983).

\section{Subgenus BASTEROTELLA Olsson and Harbison, 1953}

Like Basterotia in form, angled or carinate umbo, surface granulation and large, hook-shaped, subumbonal cardinal tooth, but differs in having both an internal and external ligament. Nymphal plate small and narrow, the resilial pit a small scar on its inner and lower face.

Geographic range.-Europe, North America.

Geologic range.-Miocene to Holocene.

Habitat.-Intertidally to $45 \mathrm{~m}$ in the Galapagos Islands. (Bernard, 1983).

\section{Basterotia (Basterotella) hertleini Durham Plate 9, figures 8, 14}

Basterotia hertleini Durham, 1950, p. 94-95, pl. 25, figs. 4, 11. Basterotia (Basterotella) hertleini Durham. Keen, 1971, p. 145, fig. 343. Bernard, 1983, p. 33.

Basterotia californica Durham, 1950, p. 94, pl. 25, figs. 9, 13.

Original description.- "Shell in general resembling $B$. peninsulare (Jordan) but more elongate and normally less inflated; subquadrate, moderately thin, ornamented by irregular concentric growth lines only; beaks not very prominent; an angulation running from umbo to posterior ventral margin; umbos situated about a fourth the length from the anterior end; a prominent projecting cardinal tooth in each valve, with adjacent deep 'socket' anterior to it in right valve." (hertleini)

"Shell small, moderately thin, elongate subquadrate, moderately inflated; ornamented by irregular concentric growth lines; beak not very prominent; an angulation running from umbo to posterior ventral margin; beak slightly anterior to midpoint of shell; a prominent projecting cardinal tooth in each valve, slanting anteriorly, a deep 'socket' adjacent posteriorly in left valve." (californica)

Holotype-UCMP 32274; of californica UCMP 32668.

Type locality.-Isla Carmen, Baja California Sur. Comondú Formation, Pliocene. Of californica, Bahía Santa Inez $\left(27^{\circ} \mathrm{N}\right.$, $\left.112^{\circ} \mathrm{W}\right)$. Unnamed Pleistocene strata.

Supplementary description.- "The smooth shell is rounded anteriorly and posteriorly in the adult, with a weak ridge setting off the posterior slope; young shells are proportionately longer, more truncate posteriorly, with a sharper ridge." (Keen, 1971, p. 145)

Comparison.- "A growth series in the Stanford collection, dredged off the Mazatlan coast, bridges the difference in outline between $B$. californica and $B$. hertleini***. At the southern end of the range the relative proportions change slightly, so that the shell seems shorter and higher; this is the $B$. ecuadoriana, which may prove to be a geographic subspecies." (Keen, 1971, p. 145) 
"This species may be distinguished from $B$. peninsulare (Jordan) by its greater length, greater width between the angulation and the posterior ventral margin, normally lesser inflation, and usually less sharp angulation." (Durham, 1950, p. 95)

Geographic range.-Living: Baja California Sur to Ecuador; fossil: Baja California Sur.

Geologic range.-Pliocene to Holocene.

Occurrence in Baja California Sur.-Pliocene: Comondú and Marquer Formations (Durham, 1950); unnamed Pleistocene sediments, Bahía Santa Inez (27 N, $112^{\circ} \mathrm{W}$ ) (Durham, 1950).

Habitat.-Intertidally, nestling in crevices and offshore to $46 \mathrm{~m}$ (Keen, 1971).

\section{Family CARDITIDAE Genus CARDITA Bruguière, 1792}

Transversally inequilateral, trapezoidal or modioliform, with nodulose radial ribs. Hinge with obliquely trigonal divergent cardinals in left valve and faint anterior laterals.

Geographic range.-Worldwide.

Geologic range.-Paleocene to Holocene.

Habitat.-The carditids are shallow-water mollusks, many attaching themselves under rocks by a byssus. (Keen, 1971)

\section{Subgenus CARDITA}

Relatively small, short; lunule not depressed.

Geographic range.-Europe, Africa, Asia, Australia, North America.

\section{Cardita (Cardita) superioris Waring Plate 4, figures 9, 11}

\section{Cardita superioris Waring, 1917, p. 91.}

Original description.--"Shell small, very convex; beaks large, incurved; anterior end deeply excavated under the beaks; margin broadly rounded; basal margin broadly curved; posterior obliquely and convexly truncated; cardinal margin sloping and slightly convex; shell slightly concave near the cardinal margin and flared; surface ornamented by about 23 broad, slightly rounded ribs which are broader than the interspaces. A few casts of this species were obtained from the upper beds. Locality 8, L.S.J.U. Pal. Coll.”

Holotype.-CAS/SU 143; CASG 61913.06.

Type locality.-SU 2696. Ventura County, Calif. Llajas Formation, Eocene.

Geographic range.-Southern California.

Geologic range.-Eocene. 1917).

Occurrence in California.-Eocene: Llajas Formation (Waring,

\section{Subgenus BYSSOMERA Olsson, 1961}

\footnotetext{
"Shell elongated, the posterior side generally wider, with a high, arched or vaulted umbonal angle extending from the beak to the posterior ventral margin, the posterior set of ribs strongly developed, the more anterior one often flattened to nearly obsolete, the anterior-ventral side depressed. Hinge weak, the lateral teeth much reduced in size and more or less vestigial. Lunule small or absent." (Olsson, 1961)
}

Geographic range.-Baja California Sur to South America. Geologic range.-Pliocene to Holocene.

\section{Cardita (Byssomera) affinis Sowerby \\ Plate 9, figures 11, 13}

Cardita affinis Sowerby in Broderip and Sowerby, 1833, p. 195.

Glans affinis (Sowerby). Grant and Gale, 1931, p. 278. Durham, 1950 , p. 72, pl. 17, figs. $2,9$.

Carditamera (Byssomera) affinis (Sowerby). Olsson, 1961, p. 189 190, pl. 26, figs. 3-3d.

Cardita (Byssomera) affinis Sowerby. Keen, 1971, p. 107, fig. 237. Original description.- "Card. testa oblonga, pallida, fuscovarid, latere antico brevi, postico elongato; costis paucis latis radiantibus, anticis obsoletiusculis, posticis prominentibus angulosis, subsquamigeris: long. 1.4 , lat. 0.6 , alt. 0.6 poll."

Holotype.-In Cummings collection.

Type locality.-_Dredged from sandy mud, at a depth of from six to twelve fathoms, in the Bay of Montejo and Gulf of Nocoiya." Holocene.

Supplementary description.- "Shell elongate, rectangular, often large (length to $70 \mathrm{~mm}$.), with the umbones and beaks placed between the anterior one-fourth and one-fifth, the anterior side, therefore, much shorter and narrower than the posterior. Dorsal and ventral margins long and fairly straight, subparallel, the anterior margin rounded, the posterior wider and subtruncate. The posterior umbonal slope is high and angular and usually more heavily sculptured. Sculpture formed by ribs, usually numbering about 17; of these, the six posterior ones and along the umbonal slope are large and usually coarsely scabrous, the others placed more anteriorly small and sometimes so low or flattened as to form smooth, colored radial rays. Hinge variable, the teeth sometimes much distorted and partly obsolete but when fully developed in the following form; the left valve has large, anterior cardinal tooth bordered on each side by deep sockets while the posterior cardinal tooth is a slender, narrow lamina separated from the nymph by a groove; the right valve has a large, slender cardinal tooth bordered in front by a deep socket; the left anterior tooth is small and placed close to the main cardinal." (Olsson, 1961, p. 190)

Geographic range.-Living: Golfo de California to Peru; fossil: Baja California Sur.

Geologic range.-Pliocene to Holocene.

Occurrence in Baja California Sur.-Pliocene: Comondú and Marquer Formations (Durham, 1950); Pleistocene: unnamed strata on Isla Carmen, Isla San Diego, Isla Coronado, and Golfo de California (Emerson and Hertlein, 1964).

Habitat.-Living in close quarters as under stones and along narrow crevices (Olsson, 1961). Intertidally to $27 \mathrm{~m}$ on the $\mathrm{Ga}$ lapagos Islands (Bernard, 1983).

\section{Subgenus STROPHOCARDIA Olsson, 1961}

"Shell rounded cordate, solid, with high umbones and strongly prosogyrately coiled beaks over a small, deeply sunken lunule. Dorsal-posterior margin flattened, escutcheon-like. Sculpture formed by relatively few, low, rounded ribs. Hinge plate massive, the right valve with a large, stout, more or less hooked cardinal tooth, the left valve with two cardinal teeth and a large central socket; no vestigial laterals." (Olsson, 1961)

Geographic range.-Living: Gulfo de California to Ecuador and the Galapagos Islands; fossil: Baja California Sur.

Geologic range.-Pliocene to Holocene. 
TABLE 2.-Geologic and geographic distribution of the genera Cyclocardia, Glans, and Miodontiscus in the eastern Pacific region

[H=Holocene; Ple=Pleistocene; Pl=Pliocene; M=Miocene; O=Oligocene; $\mathrm{Pa}=\mathrm{Paleocene}]$

\begin{tabular}{|c|c|c|c|c|c|c|c|c|c|}
\hline \multirow[t]{2}{*}{ Species } & \multirow[t]{2}{*}{ Alaska } & \multirow{2}{*}{$\begin{array}{c}\text { British } \\
\text { Colum- } \\
\text { bia }\end{array}$} & \multirow{2}{*}{$\begin{array}{l}\text { Wash- } \\
\text { ington }\end{array}$} & \multirow[t]{2}{*}{ Oregon } & \multicolumn{3}{|c|}{ California } & \multicolumn{2}{|c|}{ Baja California } \\
\hline & & & & & Northern & Middle & Southern & Norte & Sur \\
\hline \multicolumn{10}{|l|}{ Genus Cyclocardia } \\
\hline \multicolumn{10}{|l|}{ Subgenus Cyclocardia } \\
\hline barbarensis (Stearns).... & $\cdots \cdots$ & $\cdots \cdots$ & $\cdots \cdots$ & $\cdots \cdots$ & $\cdots \cdot$ & $\cdots \cdots$ & $\mathrm{P} 1$ to $\mathrm{H}$ & $\cdots \cdots$ & $\cdots \cdots$ \\
\hline californica (Dall).......... & $\cdots \cdot$ & $\cdots \cdot$ & $\cdots \cdot$ & $\cdots \cdots$ & $\cdots \cdot$ & $\mathbf{M}$ & $\mathrm{M}$ to Ple & $\cdots \cdots$ & $\cdots \cdots$ \\
\hline crebricostata (Krause)... & $\mathrm{P} 1$ to $\mathrm{H}$ & $\mathrm{H}$ & ..... & $\cdots \cdot$ & Pl to Ple & ..... & P1 & ..... & ..... \\
\hline kirkerensis (Clark)........ & $\cdots \cdot$ & $\cdots \cdot$. & $\cdots \cdot$ & $\cdots \cdot$ & $\cdots \cdots$ & $\mathrm{O}$ & $\cdots \cdot$ & $\cdots \cdots$ & $\cdots \cdots$ \\
\hline montereyana (Arnold)... & $\cdots \cdot$ & $\cdots \cdot$ & $\cdots \cdot$ & $\cdots \cdot$. & $\cdots \cdot$ & $\mathbf{M}$ & $\cdots \cdot$ & $\cdots \cdots$ & $\cdots \cdot$ \\
\hline occidentalis (Conrad).... & $\cdots \cdot$ & $\cdots \cdot$ & $\cdots \cdot$ & $\cdots \cdots$ & $\cdots \cdots$ & $\cdots \cdot$ & Pl to Ple & $\cdots \cdot$ & $\cdots \cdot$ \\
\hline ventricosa (Gould)....... & $\mathrm{M}$ to $\mathrm{H}$ & $\mathrm{M}$ to $\mathrm{H}$ & $\mathrm{M}$ to $\mathrm{H}$ & $\mathrm{M}$ to $\mathrm{H}$ & Pl to $\mathrm{H}$ & $\mathrm{H}$ & Pl to Ple & $\mathrm{H}$ & $\cdots \cdot$ \\
\hline \multicolumn{10}{|l|}{ Genus Glans } \\
\hline \multicolumn{10}{|l|}{ Subgenus Glans } \\
\hline Subgenus Centrocardita & & & $\mathrm{H}$ & & & & & & \\
\hline veneriformis (Gabb)..... & $\cdots .$. & $\cdots \cdots$ & $\cdots \cdots$ & $\cdots \cdots$ & $\cdots \cdot$ & $\mathrm{Pa} ?$ & $\cdots$ & $\cdots$ & $\ldots$. \\
\hline $\begin{array}{l}\text { Genus Miodontiscus } \\
\text { prolongatus (Carpenter) }\end{array}$ & $\mathrm{M}$ to $\mathrm{H}$ & $\mathrm{H}$ & $\mathrm{H}$ & $\mathrm{H}$ & $\mathrm{H}$ & $\mathrm{H}$ & $\mathrm{P} 1$ to $\mathrm{H}$ & ..... & $\ldots \ldots$ \\
\hline
\end{tabular}

\section{Cardita (Strophocardia) megastropha (Gray) Plate 7, figures 1, 2, 11, 14}

Venericardia megastropha Gray, 1825, p. 137, two figs. p. 138. Cardita megastropha (Gray). Hertlein and Strong, 1946, p. 106. Durham, 1950, p. 71-72, pl. 16, figs. 6, 11.

Cardita (Strophocardia) megastropha (Gray). Olsson, 1961, p. 187-188, pl. 26, figs. 5, 5a. Keen, 1971, p. 109, fig. 244. Original description.-_"Testa oblique cordata crassa albida, rufo variegata, costis convexis rugosis; margine cardinali crassissimo. long. unc. New Holland? E. dono. Dom. Bennet."

Holotype.-BM(NH)?

Type locality.-Isla La Plata, Ecuador (Hertlein and Strong, 1946). Supplementary description.- "Shell of medium or large size, solid, cordate, the ventral side rounded, the dorsal trigonal, with high umbones and strongly coiled beaks. The anterior-dorsal side is deeply impressed with a small, flattened lunule lying under and partially overhung by the beaks. Sculpture and appearance of specimens vary according to ${ }^{* * *}$ degree of wear ${ }^{* * *}$ in beach specimens***; the ribs assume greater prominence and are seen to be low, trigonal in section, their interspaces also trigonal and with a central line***." (Olsson, 1961)

Geographic range.-Living: Golfo de California to Ecuador and the Galapagos Islands; fossil: Baja California Sur to the Galapagos Islands.

Geologic range.-Pliocene to Holocene.

Occurrence in Baja California Sur.-Pliocene: Marquer Formation (Durham, 1950); Pleistocene: unnamed strata on Isla Coronado, Isla Monserrate, and Isla San Diego in Golfo de California (Emerson and Hertlein, 1964).

Habitat.-Offshore to $100 \mathrm{~m}$ (Keen, 1971); 30 to $150 \mathrm{~m}$ off the Galapagos Islands (Bernard, 1983).

\section{Genus CYCLOCARDLA Conrad, 1867}

Subtrigonal or short trapezoidal to cordiform, ventral margin well rounded; regular radial ribs may be closely spaced, crossed by numerous equidistant growth lines; beaks very small, tending to be erect.

Geographic range.-Worldwide.

Geologic range.-Cretaceous to Holocene (table 2).

\section{Subgenus CYCLOCARDIA}

Juvenile-stage ribs narrow, rounded, equally perlate, later becoming flattened and broadened, crossed by close-spaced growth lines; lunule large, smooth, slightly convex. Cardinal tooth on right valve of some species is bifid or grooved, but on other specimens this feature is faintly developed.

Geologic range.-Oligocene to Holocene (Hertlein and Grant, 1972).

Habitat.-1 to 2,210 $\mathrm{m}$ in the eastern Pacific (Bernard, 1983).

\section{Cyclocardia (Cyclocardia) kirkerensis (Clark) Plate 9, figure 12}

Cardium kirkerensis Clark, 1918, p. 140, pl. 12, fig. 5.

Original description.--"Shell small, inequilateral; beaks fairly prominent and rather strongly prosogyrous; anterior dorsal slope very slightly concave; posterior dorsal slope straight, about equal in length to the anterior slope; anterior end broadly and regularly rounded; posterior end broadly subtruncate, the lower angle of the truncation being obscure. Surface sculptured by from seventeen to twenty V-shaped, nodose, radial ribs, with interspaces 
averaging somewhat wider than the width of the ribs. Growth lines rather fine."

Holotype.-UCMP 11165.

Type locality.-UC 2033. Contra Costa County, Calif. Kirker Tuff, Oligocene .

Geographic range.-Middle California.

Geologic range.-Oligocene (table 2 ).

Occurrence in California.-Oligocene: Kirker Tuff (Clark, 1918).

\section{Cyclocardia (Cyclocardia) montereyana (Arnold) Plate 7, figure 21}

Venericardia montereyana Arnold, 1908, p. 380-381, pl. 35, fig. 4. Original description.- "Adult shell attaining a length of at least $10 \mathrm{~mm}$., width about three-fourths of length, suboval in outline, compressed; umbones near anterior extremity, small, turned toward the front; anterior extremity short, regularly rounded; posterior extremity long, obliquely projected below, quite sharply rounded; surface sculpture by about 22 moderately broad radiating ribs and numerous subequally spaced concentric lines, radiating and concentric systems together giving a cancellate appearance."

\section{Holotype.-USNM 165464.}

Type locality.-Newell Creek, $2.4 \mathrm{~km}$ north of confluence with San Lorenzo River (SW $1 / 4$, sec. 34 , T. 9 S., R. 2 W), Santa Cruz quadrangle, Santa Cruz County, Calif. Monterey Shale, Miocene.

Comparison.- "This species [C. montereyana] is probably allied to $V$. barbarensis Stearns and V. ventricosa Gould. It has more anterior umbones and has more numerous ribs (22 instead of 18) than the former, and is much flatter that the latter; its concentric sculpture is also more prominent than that in either of the recent species. Owing to the distortion of all the specimens of $V$. montereyana, it is impossible to say with certainty just what its original outline was, but it is believed to have been about as shown in the figured type." (Arnold, 1908, p. 380-381)

Geographic range.-Middle California.

Geologic range.-Miocene.

Occurrence in California.-Miocene: Monterey Shale (Arnold, 1908).

\section{Cyclocardia (Cyclocardia) californica (Dall) Plate 7, figures 3, 4}

Venericardia (Cyclocardia) californica Dall, 1903a, p. 1431, pl. 56, fig. 16.

Cardita californica (Dall). Keen and Bentson, 1944, p. 119.

Cyclocardia californica (Dall). Woodring and Bramlette, 1950, p. 85 , pl. 8 , fig. 16 ; pl. 10 , figs. 7,8 ; pl. 11 , figs. 2 , 3 ; pl. 15 , figs. 1, 2; pl. 21, fig. 5. Durham and Addicott, 1965, pl. 5, figs. 16, 17.

Original description.- "Shell of moderate size, rounded-trigonal, somewhat inequilateral; beaks small, prosogyrate, dorsal slopes steep, the anterior shorter, base arcuate; sculpture of fourteen to sixteen radial, more or less beaded or nodulous stout ribs, those on the posterior slope smaller, smoother, and less distant; interspaces channelled, subequal to the ribs; the whole with transverse concentric, somewhat irregular elevated lines. All the sculpture more feeble towards the base; lunule small, lanceolate, smooth; hinge normal, interior basal margin with a few coarse crenulations. Length 24.0 , height 21.5 , diameter $14.0 \mathrm{~mm}$."

Holotype.-USNM 164558.
Type locality.--"Pliocene(?) of California, five miles southwest of Guadalupe***," Santa Barbara County, Calif. Santa Barbara Formation, Pliocene and Pleistocene.

Supplementary description.--"This species [C. californica] is characterized by widely spaced coarse nodes. The nodes are subdued or absent toward the ventral margin of large shells and on a few shells they are subdued at an early stage***. Arnold's collection from the type locality shows a considerable range of variation in outline and in the width of interspaces. The type is exceptionally elongate and has exceptionally wide interspaces." (Woodring and Bramlette, 1950)

Geographic range.-Middle and southern California.

Geologic range.-Miocene to Pleistocene.

Occurrence in the Californias.-Miocene: Pancho Rico Formation (Durham and Addicott, 1965); Miocene and Pliocene: Sisquoc (Woodring and Bramlette, 1950) and Towsley (Kern, 1973) Formations; Pliocene: Cebada and Graciosa Members, Careaga Sandstone, Comondú Formation (Durham, 1950), and Foxen Mudstone (Woodring and Bramlette, 1950), Marquer Formation (Durham, 1950) and San Diego Formation (Rowland, 1972); Pliocene and Pleistocene: Fernando (Vedder, 1960), Santa Barbara (Dall, 1903b) and Saugus (Kew, 1924) Formations; Pleistocene: San Pedro Sand (Valentine and Meade, 1961) and unnamed strata on Isla Carmen and Isla San Marcos (Durham, 1950).

\section{Cyclocardia (Cyclocardia) occidentalis (Conrad) Plate 9, figures 3-6}

C.[ardita] occidentalis Conrad, 1855 , p. 267.1857, p. 73 , pl. 5 , fig. 24.

Cyclocardia occidentalis Conrad. Hertlein and Grant, 1972, p. 230-231, pl. 43, figs. 4-6, 9-11.

Cardita monilicosta Gabb, 1861 , p. 371

Venericardia borealis Conrad. Dall, 1874, p. 297. Not Venericardia borealis Conrad, 1831.

Original description.--"Subtriangular, equilateral; ventricose; ribs 15 , rounded, wider than the interstices, and regularly granulated by transverse lines." (occidentalis)

"Shell nearly circular; beaks small, submedian, cardinal border straight or faintly arcuate. Surface marked by from fourteen to seventeen large rounded ribs, strongly moniliform; interspaces narrow, acute. Posterior muscular impressions largest. Pallial line broad and distinct but not impressed. Internal margin coarsely crenulate, one large square tooth, corresponding with each interspace between the ribs; extreme edge undulated. Hinge robust. Length, 0.19 in.; width, 0.2 in.; depth of single valve, 0.05 in." (monilicosta)

Holotype.-Missing and presumed lost (Woodring and others, 1946), of monilicosta unknown.

Type locality.-Santa Barbara, Calif. (Conrad, 1857). Santa Barbara Formation, Pliocene and Pleistocene; of monilicosta, Santa Barbara, Santa Barbara County, Calif. Santa Barbara Formation, Pliocene and Pleistocene.

Comparison.-Cyclocardia occidentalis has 14 to 17 radial ribs and dorsal-ventral elongation. Cyclocardia ventricosa has 18 to 20 radial ribs and anterior-posterior elongation.

Geographic range.-Southern California.

Geologic range.-Pliocene to Pleistocene.

Occurrence in California.-Pliocene: San Diego Formation (Hertlein and Grant, 1972) and lower part of Saugus Formation (Squires and White, 1983); Pliocene and Pleistocene: Fernando (Arnold, 1907; Willett, 1946), San Pedro (Arnold, 1903), and Santa Barbara (Hertlein and Grant, 1972) Formations. 


\section{Cyclocardia (Cyclocardia) ventricosa (Gould) Plate 9, figures 9, 10}

Cardita ventricosa Gould, 1850, p. 276. 1852, p. 417, atlas, p. 14, pl. 36, figs. 532, 532a. Grant and Gale, 1931, p. 272, pl. 13, figs. $9 a, 9 b, 11$.

Venericardia ventricosa (Gould). Oldroyd, 1924, p. 36, pl. 3 , fig. 8. Cyclocardia ventricosa (Gould). Yonge, 1969, p. 494-505, figs. 19, 19, 24a. Hertlein and Grant, 1972, p. 231, pl. 43, figs. 3, 8. Coan, 1977 , p. $380-382$, figs. $12-15$. Roth, 1979 , p. 295 296, pl. 4, fig. 3 .

Original description.- "Testa solida, ventricosa, ovato-trigona vix obliqua, radiatim 18-20 costata, costis concentricè subnodosis, interstitiis angustis, epidermide fuliginoso, villoso induta; umbonibus submedianis, obtusis; intus alba; margine profunde crenulato; dente cardinali valvae dextrae, elevato, crasso, triangulari. Lat. $3 / 4$; alt. $5 / 8$; lat. $1 / 2$ poll."

Syntypes.-USNM 3373.

Type locality._-Hab. Puget Sound." Washington, Holocene.

Supplementary description.- "The largest of four single valves***is a left valve $16.2 \mathrm{~mm}$ long and $15 \mathrm{~mm}$ high. There are 18 radial ribs of which the posterior 5 or 6 are smaller than the others." (Hertlein and Grant, 1972)

Comparison.--"Compared with C.[ardita] borealis, Conr., it is thicker, less transverse, more tumid at the beaks, which are less recurved; the ribs are barred; the cardinal tooth is short, triangular (not long falcate) and detached from the margin; the crenulations of the margin deeper." (Gould, 1850)

"The shell of C.[ardita] ventricosa is more elongately (anteriorposterior) rounded [than Cardita occidentalis] and is sculptured with 18 to 20 rather than 14 to 17 radial ribs.

"A Recent form from Monterey, California, more elongate (anterior-posterior) than usual for this species was named $C$. [ardita] ventricosa montereyensis by A.G. Smith and Gordon. Inspection of a large series of specimens of this subspecies reveals that there are forms which imperceptibly grade into typical $C$. ventricosa.

"A small southern form, more rounded in outline and more inflated, with more sharply defined ribs, was described as C.[ardita] ventricosa redondoensis by J.Q. Burch." (Hertlein and Grant, 1972)

Geographic range.-Living: Cook Inlet, Alaska, to Baja California Norte; fossil: Washington to southern California.

Geologic range.--Miocene to Holocene; Graysian (molluscan) Stage in the Pacific Northwest (Addicott, 1976)

Occurrence in California.-Pliocene: San Diego Formation (Hertlein and Grant, 1972); Pliocene and Pleistocene: Fernando (Eldridge and Arnold, 1907; Soper and Grant, 1932; Zinsmeister, 1970), Pico (Grant and Gale, 1931), San Pedro (Arnold, 1903), and Rio Dell (Roth, 1979) Formations; Pleistocene: Timms Point Silt Member, San Pedro Formation (Arnold, 1903) and unnamed strata in southern California (Grant and Gale, 1931) and Newport Bay area, California (Kanakoff and Emerson, 1959).

Habitat. -20 to $628 \mathrm{~m}$ in the eastern Pacific (Bernard, 1983); 22 to $620 \mathrm{~m}$ (Coan, 1977); 14 to $574 \mathrm{~m}$ but more common in depths of $200 \mathrm{~m}$ or less on the southern California borderland (Jones and Thompson, 1987).

\section{Cyclocardia (Cyclocardia) crebricostata (Krause)} Plate 7, figures 23, 24; plate 9, figures 1, 2

Cardita borealis var. crebricostata Krause, 1885, p. 30, pl. 3, fig. 5. Cyclocardia crebricostata (Krause). Coan, 1977, p. 378-379, figs. 6, 7. Roth, 1979, p. 297-298.
Cyclocardia (Cyclocardia) crebricostata (Krause). Bernard, 1979, p. 40-41, figs. 63,64 .

Venericardia (Cyclocardia) alaskana Dall, 1903b, p. 710-711. \{Introduced for Venericardia borealis Conrad, 1890, in part.\}

Original description.--Die Zahl der Rippen beträgt 22-25; der Schlossrand ist dick, die Wirbel liegen central und sind nicht zerfressen; in der Nähe der Wirbel sind die Rippen durch concentrische Furchen deutlicher und regelmässiger crenulirt als bei der vorigen. Die gitterartige Sculptur der Rippen ist wie bei der vorigen. Die grössere Schale zeigt folgende Maasse: long. 24, alt. $22,1 / 2$ crass. $61 / 2 \mathrm{~mm}$." (crebricostata)

"This species is that which from the Pacific has usually been named $V$. borealis Conrad, and I can only ascribe the long acceptance of this determination, made by Dr. Carpenter, to the absence of a good series of the Eastern shell. After comparing them no one can hesitate to separate them specifically. There is a distance of several thousand miles between their nearest points of approach to each other in range, as far as known. In a general way, until Dr. Stearns looked into the matter in 1890, all the Pacific Cyclocardias were lumped together under the name of borealis Conrad.

"The present species is ovate, compressed, with 23-25 uniform and elegant radial ribs with narrower interspaces, distinct to the margin of the shell and covered with a dark yellow-brown velvety periostracum, the hairs in close radial lines. The ribs are slightly granular near the low beaks; the lunule narrow and long. The hinge is solid, with the right anterior and posterior cardinals nearly obsolete; the interior is chalky white and is figured in the Proc. U.S. Nat. Mus., XIII, pl. XVI, fig. 8, under the name of $C$. borealis. It attains a height of 35 , a length of 39 , and a diameter of $16 \mathrm{~mm}$. The animal is viviparous and incubates an enormous number of young shells until the adult sculpture is fairly initiated. The brood is fully ripe in August in the Arctic Sea, and about June 1 in the Aleutian Islands. The variability of the shell is chiefly in outline, some specimens being longer than others." (alaskana)

Lectotype.-Institut für Spezielle Zoologie und Zoologisches Museum der Humboldt-Universität, Berlin, 37934 (Coan, 1977); of alaskana USNM 109271 (Coan, 1977).

Type locality.-Saint Paul Island, Bering Sea, Alaska. Holocene; of alaskana, Bering Sea, Alaska. Holocene.

Supplementary description.- "This variable species may be recognized by its large number of ribs (22 to 25) and its heavy periostracum with radially arranged hairs. Its hinge is long and narrow, and the shells are ovate and rather compressed." (Coan, 1977, p. 379)

"Shell circular to nearly ovate, inflated, thick, maximum length $40 \mathrm{~mm}$. Surface ornamented with $18-30$ rounded ribs with equal interspaces crossed by numerous small concentric folds resulting in a scalariform appearance. Periostracum dark brown, velvety. Beaks small, erect, usually eroded. Interior polished, shell margins crenulated. Hinge delicate for the genus. Left valve with large central bifid cardinal and curved, elongated posterior cardinal tooth. Right valve with large central cardinal and thin laminar posterior cardinal tooth. External ligament placed on well-developed nymphs. Adductor muscle scars equal, deeply impressed. Pallial line impressed. No pallial sinus." (Bernard, 1979)

Comparison.- "This species is allied to the North Atlantic $C$. borealis (Conrad, 1831) but is distinguishable by the thinner shell, more delicate ribs, and weaker hinge." (Bernard, 1979)

Geographic range.-Living: Alaska and southern Sakhalin; fossil: Alaska to southern California.

Geologic range.-Pliocene to Holocene. 
Occurrence in California.-Pliocene: Lower part of the Rio Dell Formation (Roth, 1979) and lower part of the Fernando Formation (Willett, 1946); Pleistocene: Elk River Formation (Roth, 1979).

\section{Cyclocardia (Cyclocardia) barbarensis (Stearns) Plate 5, figures 9, 15}

Venericardia barbarensis Stearns, 1890, p. 214, pl. 16, figs. 3, 4. Oldroyd, 1924, p. 111-112, pl. 43, figs. 9, 11.

Cardita barbarensis (Stearns). Grant and Gale, 1931, p. 274.

Cyclocardia barbarensis (Stearns). Woodring and others, 1946, p. 82-83, pl. 31, figs. 11, 12. Coan, 1977, p. 376-377, fig. 2.

Original description.--Shell rounded, inequilateral, variable in outline, more or less oblique, moderately convex. Beaks small, slightly elevated and turned forward. Surface ornamented with nineteen to twenty radiating ribs usually somewhat granulous, and generally obscure on the extreme anterior and posterior margins of the valves. Epidermis a dingy yellowish-brown, thicker toward the ventral margin and sides of the valves thin and commonly eroded at or toward the umbos. Lunule small, slightly sunken, faintly defined. Hinge line small, not thick; hinge composed of, in the left valve, a single strong cardinal sloping posteriorly and a smaller tooth often obscure, slanting anteriorly; a third tooth-like process is generally present, situated under and apparently a projection of the edge of the lunule. This latter varies much in prominence in different specimens, and is often but barely perceptible. The hinge in the right valve is characterized by a single strong cardinal tooth with a slanting, somewhat sinuous groove above, and a slight notch and tooth-like point below the upper part of the lunule; this latter character is frequently inconspicuous and feeble. The valves are rather thin and somewhat translucent, bluish-white on the inside and showing the ribs when held up to the light. Length, 15; height, 15; diameter, $11 \mathrm{~mm}$."

Lectotype.-USNM 104045 (Coan, 1977).

Type locality.-Station 2840 off Santa Barbara, Calif. Holocene.

Supplementary description.- "Shells of this species are thin, with 19 to 20 low ribs and a thin, dark periostracum." (Coan, 1977)

Comparison.- "This species [barbarensis] has much less prominent umbones, a thinner, more elongate hinge, and more ribs than [C.] ventricosa Gould. It appears to be closer to [C.] crebicostata (Krause) and may be a southern race of that northern species." (Grant and Gale, 1931, p. 274)

"Its [C. barbarensis] hinge is narrower than that of Cyclocardia ventricosa redondoensis; its beaks are smaller, and its shape more oblique." (Coan, 1977)

Geographic range.-Living: Southern California; fossil: southern California.

Geologic range.-Pliocene to Holocene.

Occurrence in California.-Pliocene: upper part of Capistrano Formation (Kern and Wicander, 1974) and Lomita Marl Member, San Pedro Formation (Woodring and others, 1946); Pliocene and Pleistocene: Fernando Formation (Soper and Grant, 1932); Pleistocene: San Pedro and Santa Barbara Formations (Grant and Gale, 1931). ["Although reported from the Timms Point silt, San Pedro sand, and Palos Verdes sand ${ }^{* * *}$ perhaps some of the records are based on worn specimens of $C$. aff. C. occidentalis." (Woodring and others, 1946)]

Habitat. -37 to $2,210 \mathrm{~m}$ in the eastern Pacific (Bernard, 1983). From 5 to $210 \mathrm{~m}$, with some suggestion of deeper occurrence to the south; on both sand and rocky bottoms (Coan, 1977). Broods its young (Jones, 1963).

\section{Genus GLANS Mergerle von Mühfeld, 1811}

Shell bearing a general resemblance to carditids such as Carditamera but small, subquadrate in outline; hinge with well developed anterior and posterior laterals.

Geographic range.-Asia, North and East Africa, Central America.

Geologic range.-Paleocene to Holocene.

Habitat.-Intertidally to $100 \mathrm{~m}$ in the eastern Pacific (Bernard, 1983)

\section{Subgenus GLANS}

Truncate posteriorly, with nodulose or granular rounded ribs, posterior ones unequal in some species. Lateral teeth well developed.

Geographic range.-Europe, Asia, North and East Africa, North America.

\section{Glans (Glans) subquadrata (Carpenter) Plate 5, figures 10, 11}

Lazaria subquadrata Carpenter, 1864, p. 536, 627, 642.

Glans subquadrata (Carpenter). Palmer, 1958, p., 82, pl. 7, figs. 1-4. Yonge, 1969, p. 505-509, figs. 10-13, 20-22. Hertlein and Grant, 1972, p. 232, pl. 43, figs. 16, 18, 19, 22, 30. Coan, 1977, p. 382-383, fig. 16.

Glans minuscula Grant and Gale, 1931, p. 277, pl. 13, figs. 10a, 10b. [Unnecessary replacement name].

Original description.--"Hinge of Lazaria: outside like Cardita variegata juv."

Lectotype.-USNM 15681 (Coan, 1977).

Type locality.-Monterey, Calif. Holocene. (Designated by Coan, 1977).

Supplementary description.- -The outside of this remarkable little species is typically carditoid; the hinge is intermediate between Lazaria and Cypricardia." (Carpenter, 1865, p. 178)

"A minute left valve***has a well-preserved prodissoconch sculptured with strong concentric lamellae. Well-preserved minute Recent shells show the same prodissoconch sculpture." (Woodring and Bramlette, 1950)

Geographic range.-Living: British Columbia to Baja California Sur; fossil: southern California to Baja California Sur.

Geologic range.-Pliocene to Holocene.

Occurrence in California.-Pliocene: Cebada Member of the Careaga Sandstone (Woodring and Bramlette, 1950), San Diego (Hertlein and Grant, 1972), and lower part of the San Pedro (Grant and Gale, 1931) Formations; Pleistocene: unnamed strata in southern California and Baja California Norte and Sur (Jordan, 1926; Valentine, 1957; Valentine and Meade, 1961; Valentine and Roland, 1969), and on San Nicolas Island (Vedder and Norris, 1963).

Habitat.-Intertidal zone to $91 \mathrm{~m}$ (Hertlein and Grant, 1972); intertidal to $100 \mathrm{~m}$ (Bernard, 1983). Almost all records are from rocky areas where the animal attaches itsef to rocks with a byssus (Coan, 1977). It broods its young (Yonge, 1969).

\section{Subgenus CENTROCARDITA Sacco, 1899}

Posterior margin rounded, with equal squamose or echinate ribs. Hinge with almost obsolete small laterals. 
Geographic range.-Europe, East Africa, Australia, western North America.

Geologic range.-Eocene to Holocene.

\section{Glans (Centrocardita) veneriformis (Gabb) Plate 7, figures 7-9}

Cardita veneriformis Gabb, 1864, p. 215, pl. 32, figs. 285, 285 a. Dickerson, 1914, p. 131.

"Cardita" veneriformis Gabb. Stewart, 1930, p. 173, pl. 3, fig. 7.

Glan[s] (Centrocardi[t]a) veneriformis Gabb. Zinsmeister, 1983, p. 63.

Original description.- "Shell small, very convex, subquadrate beaks rather large, strongly incurved; cardinal margin nearly straight; posterior end obliquely and convexly truncated; anterior end deeply excavated under the beaks, produced and narrowly rounded below; base broadly rounded; lunule broad, deeply impressed. Surface marked by about forty fine, acute, radiating ribs, with sometimes an intercalated one arising in the middle of the shell, and becoming as large as the others before it reaches the base; these are most numerous anteriorly, where all of the ribs are smaller than on the middle; margin strongly crenulated."

Holotype.-ANSP 4381.

Type locality.-West of Martinez, Contra Costa County, Calif. Paleocene(?).

Supplementary description.-"The lunule is wide and impressed, the escutcheon is not preserved. There are six radial ribs to the two $\mathrm{mm}$. interval on the central ventral margin. Some of the radial ribs near the anterior ventral border are apparently secondary and did not extend to the umbo. The ligament was opisthodetic. The hinge is unknown. Length, $9.8 \mathrm{~mm}$; height, $8.4 \mathrm{~mm}$; thickness of both valves, $7.5 \mathrm{~mm}$." (Stewart, 1930 , p. 173)

Geographic range.-Middle California.

Geologic range.-Paleocene(?).

Occurrence in California.-Paleocene(?): Martinez Formation(?) (Dickerson, 1914; Stewart, 1930).

\section{Genus MIODONTISCUS Dall, 1903}

Small, obliquely oblong, with strongly prosogyrate beaks and long, ill-defined lunule; sculpture of broad radial ribs crossed by concentric furrows.

Geographic range.-Western North America, Japan.

Geologic range.-Miocene (Japan) to Holocene.

Habitat. -9 to $128 \mathrm{~m}$ (Hertlein and Grant, 1972); 5 to $210 \mathrm{~m}$ in the eastern Pacific (Bernard, 1983).

\section{Miodontiscus prolongatus (Carpenter) Plate 5, figures 12-14, 16}

Miodon prolongatus Carpenter, 1864, p. 611, 627, 642.

Miodontiscus prolongatus (Carpenter). Palmer, 1958, p. 83, pl. 8, figs. 1-7. Hertlein and Grant, 1972, p. 233-234, pl. 56 figs. 1-5. Coan, 1977, p. 383-384, figs. 17-19.

Venericardia yatesi Arnold, 1907, p. 439-440, pl. 58, figs. 2a. 2b.

Original description.-"Outside Lucinoid; hinge and scars nearer to Venericardia. Congeneric with Astarte orbicularis, J. Sby. Min. Conch. pl. 444, f. 2, 3 (non ejusdem, pl. 520, f. 2). G. Oolite; and with the Crag Cardita corbis." (prolongatus)

"Shell averaging between 4 and 5 millimeters in altitude, subcircular in outline, moderately convex. Beaks slightly posterior, turned slightly forward, and somewhat prominent. Anterior margin slightly depressed in front of beaks, but convex below this; anterior angle somewhat more sharply rounded than posterior, giving the valve an obliquely protruding appearance anteriorly. Posterior margin and base regularly rounded. The sculpture consists of 8 or 9 broad falcate ribs separated by narrow incised interspaces and several ( 8 in the type) very prominent concentric imbrications of growth; in addition to the latter are numerous fine incremental lines. Hinge relatively narrow for one of this genus." (yatesi)

Lectotype.-USNM 15472 (Coan, 1977); holotype of yatesi USNM 165248

Type locality.-Neah Bay, Washington. Holocene; of yatesi Bath-house Beach, Santa Barbara, Santa Barbara County, Calif. Fernando Formation, Pleistocene.

Supplementary description.--"Typical specimens of Miodontiscus prolongatus are about $5 \mathrm{~mm}$ in length and in height. They are trigonally subcircular in outline with rather prominent, erect beaks which are slightly curved anteriorly. The external sculpture consists of broad, low, radiating ribs and widely spaced concentric, incised lines." (Hertlein and Grant, 1972, p. 233)

Geographic range.-Living: Alaska to southern California; fossil: Russia, Alaska, and southern California.

Geologic range.-Pliocene to Holocene.

Occurrence in California.-Pliocene: Cebada and Graciosa Members of the Careaga Sandstone (Woodring and Bramlette, 1950), Foxen Mudstone, Lomita Marl Member, of the San Pedro Formation, and San Diego Formation (Hertlein and Grant, 1972); Pliocene and Pleistocene: Santa Barbara Formation; Pleistocene: Timms Point Silt Member, San Pedro Formation (Woodring and others, 1946) and unnamed strata at Newport Bay, and on San Nicolas Island (Vedder and Norris, 1963), Calif.

Habitat. -9 to $55 \mathrm{~m}$ (Hertlein and Grant, 1972); 5 to $210 \mathrm{~m}$ in the eastern Pacific (Coan, 1977; Bernard, 1983).

\section{Subfamily VENERICARDINAE Genus VENERICARDIA Lamarck, 1801}

Rounded trigonal, inequilateral, thick-shelled, with numerous radial ribs evenly elevated at young stage but becoming flattened and enlarged on adults.

Geographic range.-Europe, Africa, North America.

Geologic range.-Late Cretaceous to Eocene (table 3).

Geographic range.-Europe, Africa, North America, New Zealand.

Comments.-Figure 3 shows the phylogeny of Venericardia in the eastern Pacific.

\section{Subgenus PACIFICOR Verastegui, 1953}

Subtrigonal to rounded; immature ribs trifid, later becoming simple and rounded, nodulose to irregularly striated.

The posterodorsal area in the left valve is smoother than in the right, has fewer ribs, and the ribs are weaker.

Geographic range.-Europe?, North America.

Geologic range.-Late Cretaceous to Eocene.

Comments.-Figure 3 shows the phylogeny of Pacificor in the eastern Pacific. 
TABLE 3.-Geologic and geographic distribution of the genera Venericardia, Glyptoactis, and Milneria in the eastern Pacific region

[H=Holocene; $\mathrm{Pl}=\mathrm{Pliocene} ; \mathrm{E}=$ Eocene; $\mathrm{Pa}=\mathrm{Paleocene} ; \mathrm{K}=$ Cretaceous $]$

\begin{tabular}{|c|c|c|c|c|c|c|c|}
\hline \multirow[t]{2}{*}{ Species } & \multirow{2}{*}{$\begin{array}{l}\text { Wash- } \\
\text { ington }\end{array}$} & \multirow[t]{2}{*}{ Oregon } & \multicolumn{3}{|c|}{ California } & \multicolumn{2}{|c|}{ Baja Californic } \\
\hline & & & Northern & Middle & Southern & Norte & Sur \\
\hline \multicolumn{8}{|l|}{ Genus Venericardia } \\
\hline \multicolumn{8}{|l|}{ Subgenus Pacificor } \\
\hline aragonia diabloensis (Verastegui).......... & $\cdots \cdot$ & $\cdots \cdot$ & $\cdots \cdot$ & E & $\cdots \cdot$ & $\mathrm{Pa} ?$ & $\cdots \cdot$ \\
\hline aragonia joaquinensis (Vokes).............. & $\cdots \cdot$ & $\cdots \cdots$ & $\cdots \cdot$ & $\mathrm{E}$ & $\mathrm{Pa}$ to $\mathrm{E}$ & $\mathrm{E}$ & $\cdots \cdot$ \\
\hline calafia calafia (Stewart)............................ & $\cdots \cdots$ & $\mathrm{E}$ & $\cdots \cdot$ & $\cdots \cdot$ & $\mathrm{E}$ & $\cdots \cdots$ & $\cdots \cdot$ \\
\hline calafia gabbi (Verastegui)..................... & $\cdots \cdot$ & $\cdots \cdots$ & $\cdots \cdot$ & $\cdots \cdot$ & $\mathrm{E}$ & $\cdots \cdots$ & $\cdots \cdots$ \\
\hline calafia lutmani (Turner)........................... & $\cdots \cdot$ & $\mathrm{E}$ & $\cdots \cdot$ & $\cdots \cdots$ & $\mathrm{E}$ & $\mathrm{E}$ & $\cdots \cdots$ \\
\hline calafia susanaensis (Verastegui)............. & $\cdots \cdot$ & $\cdots \cdots$ & $\cdots \cdot$ & $\cdots \cdot$ & $\mathrm{E}$ & $\cdots \cdots$ & $\cdots \cdot$ \\
\hline clarki clarki Weaver and Palmer........... & $\mathrm{E}$ & $\cdots \cdots$ & $\cdots \cdot$ & $\cdots \cdot$ & $\mathrm{E}$ & $\cdots \cdot$ & $\cdots \cdots$ \\
\hline clarki popenoei (Verastegui).................. & $\cdots \cdot$ & $\cdots \cdot$ & $\cdots \cdot$ & $\cdots \cdots$ & $\mathrm{E}$ & $\cdots \cdots$ & $\cdots \cdots$ \\
\hline 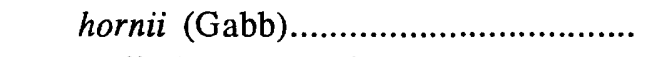 & $\cdots \cdot$ & $\mathrm{E}$ ? & $\cdots \cdot$ & $\cdots \cdot$ & $\mathrm{E}$ & $\cdots \cdot$ & $\cdots \cdots$ \\
\hline 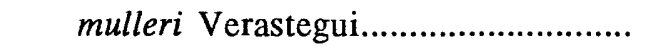 & $\cdots \cdot$ & $\cdots \cdots$ & $\cdots \cdot$ & $\mathrm{Pa}$ & $\mathrm{Pa}$ & $\cdots \cdot$ & $\cdots \cdot$ \\
\hline 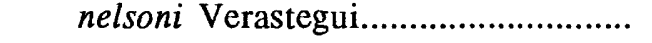 & $\cdots \cdot$. & … & .... & … & $\mathrm{Pa}$ & $\cdots \cdots$ & $\cdots \cdots$ \\
\hline taliaferroi Verastegui................................. & $\cdots \cdot$ & $\cdots \cdots$ & $\cdots \cdot$ & $\cdots$. & $\mathrm{K}$ to $\mathrm{Pa}$ & $\cdots \cdot$ & $\cdots \cdot$ \\
\hline \multicolumn{8}{|l|}{ Subgenus Venericor } \\
\hline 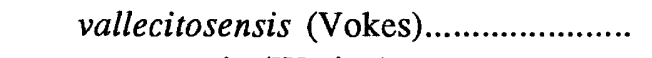 & $\cdots$. & $\cdots \cdot$ & $\cdots \cdot$ & $\mathrm{E}$ & $\cdots \cdot$ & $\cdots \cdot$ & $\cdots \cdot$ \\
\hline 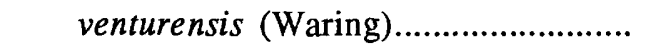 & $\cdots \cdot$ & $\cdots \cdot$ & $\cdots \cdot$ & $\mathrm{Pa}$ & $\mathrm{Pa}$ & $\mathrm{Pa}$ & $\cdots \cdots$ \\
\hline \multicolumn{8}{|l|}{ Genus Glyptoactis } \\
\hline \multicolumn{8}{|l|}{ Subgenus Claibornicardia } \\
\hline 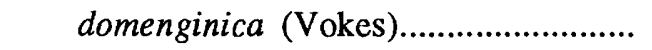 & $\cdots \cdot$ & $\cdots \cdot$. & $\cdots \cdot$ & $\mathrm{E}$ & $\mathrm{E}$ & $\cdots \cdots$ & $\cdots \cdot$ \\
\hline 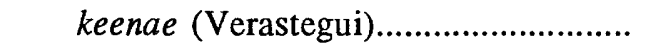 & $\cdots \cdot$ & $\cdots \cdot$ & $\cdots \cdot$ & $\mathrm{Pa}$ & & $\cdots \cdots$ & $\cdots \cdots$ \\
\hline 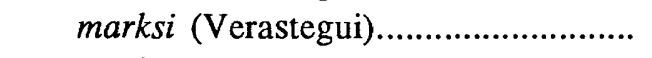 & $\cdots \cdot$ & $\cdots \cdots$ & $\cdots \cdot$ & $\cdots \cdot$ & $\mathrm{E}$ & $\cdots \cdots$ & $\cdots \cdots$ \\
\hline sandiegoensis (M.A. Hanna)................ & $\cdots \cdot$ & $\cdots \cdot$ & $\cdots \cdot$ & $\mathrm{E}$ & $\mathrm{E}$ & $\cdots \cdot$ & $\cdots \cdot$ \\
\hline \multicolumn{8}{|l|}{ Genus Milneria } \\
\hline 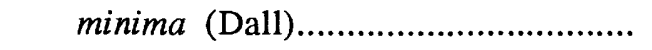 & $\cdots \cdot$ & $\cdots \cdot$ & $\cdots \cdot$. & $\mathrm{H}$ & $\mathrm{Pl}$ to $\mathrm{H}$ & $\mathrm{H}$ & $\mathrm{H}$ \\
\hline
\end{tabular}

\section{Venericardia (Pacificor) taliaferroi Verastegui} Plate 5, figures 3, 7, 8

Venericardia venturensis Waring. Taliaferro, 1944, p. 516. Not Venericardia venturensis Waring, 1917.

Venericardia (Pacificor) taliaferroi Verastegui, 1953, p. 38-39, pl. 1, figs. 15, 16. Saul, 1986, p. 29, figs. $39,40$.

Original description.- "Shell small, convex, outline obliquely cordate, anterior and ventral margins broadly rounded, the posterior obtusely truncate, the postero-dorsal somewhat arched; umbonal area convex; beak prosogyrate, curved forward, low, at about the anterior one-fourth. Posterior area depressed, slightly concave, characterized by finer ribbing. Sculpture (well preserved in the holotype) consisting of 20 to 22 ribs; the anteriormost 3 ribs $\mathrm{V}$-shaped, the next 11 ribs tripartite with lateral terraces about one-fifth the width of the radials; ribs separated by $U$. shaped channels; the posterior 7 ribs V-shaped, the second from the last a little higher than the rest; interradials apparently obtusely V-shaped; with fine incrementals on the umbonal area, anteriorly coarsened to give the radials the appearance of being crenulated; periodic constrictions of growth (annual rings) well marked. Lunule impressed, slopes downward and forward. Hinge and interior of the types concealed by coarse matrix."

Holotype.-CAS/SU 7996; CASG 66526.01.

Type locality.-NW1/4, NE $1 / 4$, sec. 30 , T. 25 S., R. 10 E., $1 / 4$ mile SSW [0.4 km] of Bench Mark 719, south of Williams Ranch on the Nacimiento River, Adelaida Quadrangle, San Luis Obispo County, Calif. Dip Creek Formation of Verastegui (1953), Upper Cretaceous and Paleocene.

Comparison.-"Venericardia taliaferroi ${ }^{* * *}$ was originally misidentified as $V$. venturensis Waring. The round ribs and the typical Pacificor distribution of fasciculate (terraced) ribs show that it is unrelated to $V$. venturensis which belongs to the subgenus Venericor**" (Verastegui, 1953).

Geographic range.-Southern California.

Geologic range.--Late Cretaceous to Paleocene.

Occurrence in California.-Upper Cretaceous and Paleocene: Dip Creek Formation (Verastegui, 1953); Paleocene: basal part of San Francisquito Formation (Saul, 1986). 


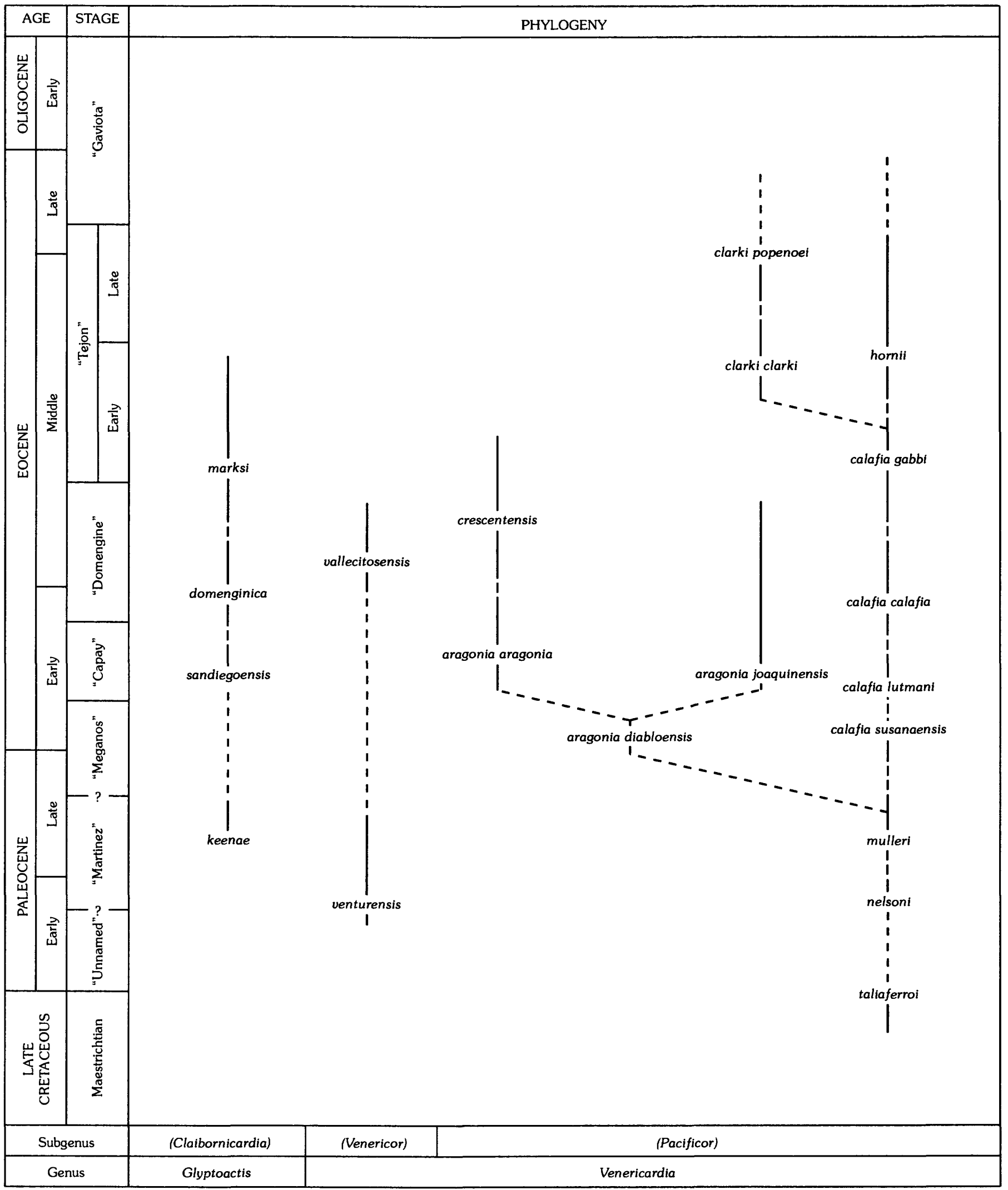

Figure 3.-Preliminary phylogenetic chart of Glyptoactis and Venericardia prepared by LouElla Saul, Los Angeles County Museum of Natural History. The species aragonia s. s. and crescentensis do not occur in the Californias but are found in Oregon and Washington, respectively. Stage names in quotation marks distinguish them from formations of the same name. 


\section{Venericardia (Pacificor) nelsoni Verastegui}

Plate 1, figures 3, 20

Venericardia planicosta var. venturensis Waring. Nelson, 1925, p. 403 [faunal list]. Not Venericardia venturensis Waring, 1917.

Venericardia (Pacificor) nelsoni Verastegui, 1953, p. 21-22, pl. 2, figs. 1, 5; pl. 3, fig. 5. Zinsmeister, 1983, pl. 1, fig. 20. Saul, 1983 , pl. 1, fig. 7 .

Venericardia (Pacificor) transversaria Verastegui, 1953, p. 3738, pl. 2, figs. 2-4.

Original description.- "Shell large, heavy, ovate; outline smoothly rounded, umbo inflated, prosogyrate; the medial area defined by a sudden change of slopes on the anterior and posterior sides. Sculpture not well preserved in holotype; radials consisting of 22 rounded ribs which become obsolete toward the ventral border; umbonal sculpture in holotype lost by weathering; posterior area set off by five thin, crowded radials succeeded by two outermost ribs which are conspicuously wider; interradials linear; incrementals moderately strong, crowded in senile stage and producing a conspicuous thickening of the borders. Lunule of the left valve narrow, pointing downward and backward; pseudoescutcheon present, slightly concave, wide, bordered by a narrow ligamental groove; nymph long and narrow; ligamental pit large, excavated in a prolongation of the nymph. Hinge plate heavy, low and short with a sinuous ventral margin; left anterior cardinal (2) long trigonal, obliquely set, posterior cardinal (4b) relatively thin, slightly broadening ventrally. Interior of holotype filled with matrix concealing the pedal and adductor muscle scars; crenulations on the inner margin not distinct." (nelsoni)

"Shell large, thick, inflated, outline subquadrate. Umbo prominent, strongly curved forward (unfortunately beak, lunule, and part of the hinge are broken in the holotype); anterior margin broadly rounded, ventral margin gently curved, turning abruptly about $90^{\circ}$ to the straight posterior margin. With typical Pacificor sculpture modified by superimposed wrinkled laminations consisting of 22 ribs; the 6 anterior radials characterized by having lateral riblets not reaching the anterior margin; 4 of the 6 ribs on the posterior area thin, 2 marginal ribs wider. Interradials linear in the antero-medial portion, becoming gradually wider and U-shaped in the posterior area. Pseudoescutcheon wide, concave, and distinct. Ligamental groove well developed. Hinge heavy, high, and short with a sinuous basal line; dentition not well preserved in the holotype, except the base of the massive and curved middle right cardinal (3b). Pedal muscle scar deep and large; adductor muscle scars deeply impressed. Shell conspicuously thickened at the posteroventral point of the posterior scar; pallial line irregular, rather far removed from the margin; inner marginal crenulations very coarse." (transversaria)

Holotype.-UCMP 32804; of transversaria UCMP 32804A.

Type locality.-UC 3765. Ventura County, Calif. Santa Susana Formation of Zinsmeister (1983), Paleocene; of transversaria UC 3765. Ventura County, Calif. Santa Susana Formation of Zinsmeister (1983), Paleocene.

Comparison.- "V. mulleri has about 12 more ribs and***its lunule points downward and forward." (Verastegui, 1953, p. 22)

Geographic range.-Southern California.

Geologic range.-Paleocene.

Occurrence in California.-Paleocene: Martinez (Verastegui, 1953) and Santa Susana (Zinsmeister, 1983) Formations.

\author{
Venericardia (Pacificor) mulleri Verastegui \\ Plate 1, figures 1, 5, 11
}

Venericardia (Pacificor) mulleri Verastegui, 1953, p. 20-21, pl. 2, figs. 1, 5; pl. 3, fig. 5. Saul, 1983, pl. 1, fig. 8 .

Venericardia mulleri Verastegui. Smith, 1975, p. 470, pl. 2, fig. 8.

Original description.- "Shell of medium to large size, gently convex, rounded in outline with broadly arcuate anterior and ventral margins and obtusely truncate posterior margin; narrow pointed umbones and low prosogyrate beaks at the anterior fourth. Surface ornamentation consists of 32 to 34 well-defined ribs extending from the beak to the margin, 24 ribs on the antero-medial portion and approximately 10 on the posterior area; faint, terrace-like secondary riblets evident on both sides of the first 10 anterior ribs and receding to the posterior umbonal area. Riblets one-fifth nearer the dorsal margin broaden away from the beak, and in the adolescent stage usually have one secondary riblet on the posterior side of the ribs; the remaining seven ribs narrower, crowded, and cordlike; (beak areas poorly preserved in all specimens examined). Interspaces are V-shaped at the umbo but become shallower and less sharply angular in harmony with the rib crests which are sharp near the umbo and increasingly rounded ventrally. Growth lines present throughout, more apparent in the anterior area, where they intercept the crests of ribs and give the appearance of nodes. Pseudoescutcheon present. Lunule short and deep, sloping forward, distinctly convex, outlined by an incised groove, ending ventrally in a depression in the right valve. Ligament opisthodetic, nymph narrow and elongate; ligamental pit shallow, elongate and bordered dorsally by an extension of the nymph. Hinge plate low, short, with ventral border distinctly sinuous; dentition of the right valve with a laminar anterior cardinal (3a) barely discernible on the posterior side of the lunular body, a medial obliquely cuneate cardinal (3b), and a slender posterior cardinal (5b). Pedal and adductor muscle scars not deeply incised. Pallial line entire and relatively far from the ventral margin. Crenulations of inner margin well marked in adolescent shell but obscure on a mature form."

Holotype: CAS/SU 7994.

Type locality.-SU 2073. Fresno County, Calif. Base of Lodo Formation, Paleocene.

Comparison.- "V. argentea, a contemporaneous form, differs from $V$. mulleri by its pronounced umbonal convexity with fuller umbones, and by the somewhat flatter ribs in the adolescent shell. $V$. nelsoni***resembles $V$. mulleri in the general outline of the shell but is distinguished by having only 21 ribs. $V$. susanaensis***seems to be closely related to $V$. mulleri." (Verastegui, 1953, p. 21)

Geographic range.-Middle and southern California.

Geologic range.-Paleocene.

Occurrence in California.-Paleocene: Coal Canyon Formation and basal part of Lodo Formation (Verastegui, 1953; Smith, 1975).

\section{Venericardia (Pacificor) calafia susanaensis Verastegui Plate 1, figures 14, 16-18}

Venericardia (Pacificor) susanaensis Verastegui, 1953, p. 22-23, pl. 5, figs. 1-4.

Venericardia (Pacificor) hornii susanaensis Verastegui. Saul, 1983, pl. 1, fig. 14. 
Original description.- "Shell, large, thin, outline rounded to subquadrate, not known in detail due to the fragmentary nature of the material; umbonal area narrow, slightly inflated; beaks prosogyrate, distinctly low and pointing forward. Sculpture of holotype well preserved; 22 ribs, persisting to the margins, in the antero-medial portion and 8 in the posterior area; earliest ribs worn away but that which remains shows that they are tripartite and faintly beaded, at least in the anterior part of the shell; in the mature stage, the ribs of the antero-medial area rounded, those on the posterior area thin and crowded; the interradials V-shaped, reaching the ventral margin. Incrementals rough throughout the shell. Pseudoescutcheon narrow, concave, showing oblique lines of growth. Ligamental groove narrow; nymph thin and large, embracing anteriorly a linear ligamental pit. Hinge plate short and low with a sinuous basal margin, the sinuosity more pronounced in the right valve; dentition of arcuate-cuneate middle cardinal ( $3 \mathrm{~b})$, slightly concave on the wide basal margin, and a cordate posterior cardinal (5b) on the inner border of the nymph body; the left valve with a trapezoido-pyramidal, strong anterior cardinal (2), and a thin posterior left cardinal (4b), slightly thickened toward the ventral end. Interior of the holotype badly preserved; pedal muscle scars small and shallow, part of the shallowly incised posterior adductor muscle scar visible, posterior adductor scar placed unusually far from the hinge plate. Inner margin strongly crenulate."

Holotype.-CAS/SU 8004; CASG 66527.01.

Type locality._-SU CA-33, McCray Oil Wells, Oil Canyon, Camulos Quad., Ventura Co., California." Uppermost Santa Susana Shale of Verastegui (1953), Eocene.

Geographic range.-Southern California.

Geologic range.-Eocene.

Occurrence in California.-Paleocene and Eocene: Santa Susana Shale (Verastegui, 1953)

\section{Venericardia (Pacificor) aragonia diabloensis Verastegui Plate 2, figures 8, 9; plate 5, figures 2, 5}

Venericardia hornii Gabb, n. var.?. Clark and Woodford, 1927, p. 92 , pl. 15.

Venericardia (Pacificor) diabloensis Verastegui, 1953, p. 27-28, pl. 5, figs. 5-7, 7a.

Original description.-_Shell large, slightly subquadrate, with inflated umbo and flattened ventral area; anterior margin broadly rounded, the ventral gently curved, and the posterior slightly truncate; beaks massive and curved forward, placed at about the anterior one-third. Umbonal sculpture consisting of 26 finely beaded and in the anterior medial area laterally terraced ribs; on the posterior portion ribs cordlike, crowded and less distinct; adult sculpture characterized by 26 gently rounded, almost flat ribs separated by linear intercostals, ribs and intercostals gradually disappear with growth about $50 \mathrm{~mm}$. from the beak, giving place to thick incrementals. Lunule convex, deeply inset, with lunular margin sloping almost vertically and ending in a pustule (in the left valve). Ligamental groove shallow. Hinge plate moderately high and long with a slightly sinuous ventral margin; nymph narrow but long; ligamental pit triangular, deeply incised. Dentition of the left valve consists of a scimitar-like, cuneate anterior cardinal (2), pointing toward and touching the lunular plate, with the inner face sloping uniformly toward the ventral margin of the hinge, and a thin posterior cardinal (4b), also sloping. Interior of the type filled with matrix, concealing the pedal and adductor muscle scars. Inner margins crenulate."
Holotype.-CAS/SU 411; CASG 61967.01.

Type locality.--Marsh Creek, Brentwood, Contra Costa Co., California." Meganos Formation, Paleocene and Eocene.

Comparison.- "V. diabloensis closely resembles V. lutmani Turner from Oregon in outline but differs in having two less ribs than the latter." (Verastegui, 1953, p. 28)

Geographic range.-Middle California and Baja California Norte? (Flynn and others, 1989).

Geologic range.-Paleocene and Eocene.

Occurrence in Californias.-Paleocene(?): Bateque Formation (Flynn and others, 1989); Paleocene and Eocene: Meganos Formation (Verastegui, 1953).

\section{Venericardia (Pacificor) calafia lutmani Turner}

Plate 2, figures 1, 2; plate 4, figures 1, 12, 13; plate 5, figure 1

Venericardia hornii subsp. lutmani Turner, 1938, p. 50, pl. 13, fig. 4; pl. 14, fig. 2. Weaver, 1942, p. 135, pl. 28, fig. 1; pl. 32, fig. 1.

Venericardia (Pacificor) lutmani Turner. Verastegui, 1953, p. 26 27, pl. 7, figs. 305; pl. 8, fig. 8 .

Venericardia (Pacificor) hornii lutmani Turner. Givens, 1974, p. 47, pl. 1, fig. 16; pl. 2, fig. 8. Saul, 1983, pl. 2, fig. 6.

Venericardia (Pacificor) durhami Verastegui, 1953, p. 23, pl. 7, figs. 1, 2. Flynn and others, 1989, p. 1,184, fig. 4 (4).

?Venericardia (Pacificor) diabloensis Verastegui. Flynn and others, 1989, p. 1,184, Fig. 4 (2A, 2B). Not Venericardia (Pacificor) diabloensis Verastegui, 1953.

Original description.--"Shell heavy, subquadrate; beaks small; 27 ribs, the posterior 9 or 10 narrower and higher than the remainder, which are nearly obsolete with the exception of the anterior three or four; lunule very short, deep; ligamental groove long, narrow."

"Shell large, thick, distinctly round in outline; umbones inflated with the anterior slope more sharply curved than the posterior; beaks low, prosogyrate, situated at about the anterior one-third. Sculpture of 28 interradials, faintly represented over the main part of the disk; (sculpture on tips of beaks of holotype worn and not showing whether ribs are beaded or fasciculate); the antero-medial portion with 19 ribs and the posterior area with only 9 , the 4 nearest to the dorsal margin being wider than the others. Lines of growth conspicuous over the greater part of the shell. Incrementals faint and smooth up to $25 \mathrm{~mm}$. diameter becoming gradually coarser; dominating over obsolescent radial sculpture; a distinctive feature of the species. Lunule not well preserved, apparently small and deeply incised. Pseudoescutcheon narrow and concave. Hinge plate low and short; dentition in holotype poorly preserved, traces of the cardinal (2) of the left valve, and the anterior cardinal (3a) of the right valve resemble those of Venericardia susanaensis, n. sp. Interior of holotype concealed by matrix." (durhami)

Holotype.-UCMP 33133; of durhami CAS/SU 8005; CASG 66528.01 .

Type locality.-UC A-1233. Douglas County, Oreg. Umpqua Group, Roseburg Formation of Baldwin (1974), Eocene; of durhami "SU 829. $2.4 \mathrm{~km} \mathrm{W.} \mathrm{of} \mathrm{Vickers} \mathrm{Hot} \mathrm{Springs,} \mathrm{Ventura}$ Co., California." Juncal Formation, Eocene.

Supplementary description.-"Shell large, heavy, subquadrate in outline, anterior end evenly rounded, ventral gently curved, posterior truncate; umbones inflated, with low, pointed beaks situated at about the anterior one-fourth. Sculpture in holotype not well preserved; 20 ribs in the antero-medial portion; only 6 ribs preserved on anterior area, these show riblets which do not 
reach the anterior margin; the visible intercostals linear; incrementals coarse and over-ride ribs in the anterior area but fine on the obsolescent ribs of the ventral area. Lunule small, convex, deeply inset, sloping downward and slightly forward, the right lunule three times as large as the left one. Pseudoescutcheon present, flat and wide (not well preserved). Nymph thin and large ligamental pit deeply incised. Hinge plate high and long, with a sinuous ventral margin. Dentition strong, consists of a laminar, long, nearly vertical anterior right cardinal (3a), pointed downward and slightly backward; a flat, scimitar-like, ventrally sinuous medial right cardinal $(3 \mathrm{~b})$; a cordlike posterior right cardinal (5b) placed on a wide flat nymphal body; the left valve with a low, cuneate anterior cardinal (2), the upper end touches the lunular plate, and a thin, low posterior left cardinal (4b), not well preserved in the holotype. Pedal muscle scars shallowly incised; the rest of the interior of the shell concealed by the matrix." (Verastegui, 1953, p. 27)

Comparison.- "The new subspecies differs from $V$. hornii calafia Stewart in having three or four additional ribs. Specimens of the new subspecies from the Santa Susana shale of the Simi Valley region have 28 or 29 ribs and may be the initial form from which the later varieties or subspecies of $V$. hornii evolved by progressive elimination of ribs." (Turner, 1938: 50)

"This subspecies is distinguished from $V$. hornii by possessing 27 ribs and a low beak while the latter is characterized by 22 wide rounded closely spaced radial ribs. It differs from the subspecies calafia in having 3 or 4 more radial ribs. On the middle third of the shell the width of ribs is approximately two-thirds that of the interspaces." (Weaver, 1942, p. 135)

"This subspecies [lutmani] is similar in outline to $\mathrm{V}$. hornii calafia, but is distinguished by a larger number (27-30) of radial ribs. As suggested by Turner (1938:50), V. hornii lutmani probably evolved into $V$. hornii calafia by reduction in the number of ribs." (Givens, 1974, p. 47)

Geographic range.-Southern Oregon, southern California, and Baja California Norte.

Geologic range.-Eocene.

Occurrence in the Californias.-Eocene: Bateque, Juncal, and basal part of Llajas Formations (LouElla Saul, written commun., 1989).

\section{Venericardia (Pacificor) calafia calafia Stewart Plate 3, figures 1-7, 11, 16, 19}

Venericardia hornii subsp. calafia Stewart, 1930, p. 168-170, pl. 11, fig. 2. Turner, 1938, p. 50, pl. 14, fig. 4. Weaver, 1942 , p. 134 , pl. 28 , figs. 6,7 ; pl. 31 , figs. 4,5 .

Venericardia (Pacificor) calafia Stewart. Verastegui, 1953, p. 28-30.

Venericardia (Pacificor) hornii calafia Stewart. Saul, 1983, p. 79, pl. 2, figs. 9, 16, 17. Squires, 1984, p. 46, figs. 10n, 0 .

Venericardia (Pacificor) oregonensis Verastegui, 1953, p. 25, pl. 9, figs. 7-9.

Venericardia (Pacificor) hertleini Verastegui, 1953, p. 24-25, pl. 15 , figs. $1,2,6$.

Venericardia hornii (Gabb), variety, Hanna, 1925, p. 286-287, pl. 38, fig. 4; pl. 40, figs. 1(?), 2.

Original description.- -Shell large, heavy, almost circular, with small beaks: 24 radiating ribs on each valve, decorticated at the beaks, but a few of the anterior ribs still showing the lateral ridges and two of the posterior ribs of the left valve distinctly noded but apparently not ridged; on the central region, the ribs flatten and disappear when the shell is about $42 \mathrm{~mm}$. long, as shown by the growth lines, the central area being quite smooth; the anterior ribs gradually give way to prominent growth lines while the posterior ribs remain more or less distinct, but not prominent, to the posterior margin: hinge of type specimen not exposed. Length, $95 \mathrm{~mm}$.; height, $86 \mathrm{~mm}$.; thickness of both valves, $53.5 \mathrm{~mm}$.; no. 31450, Museum of Paleontology." (calafia)

"Shell large, thick, broadly rounded, not strongly inflated; antero-ventral margin broadly rounded, the posterior slightly truncated. Umbo curved forward; beak placed at about the anterior one-third; posterior area flattened, somewhat concave and defined by a sudden change from coarse to fine ribs. Sculpture consists of 25 ribs which become obsolete near the margins. The 18 ribs in the antero-medial portion sharply angular on the beak, gradually become slightly flattened to the second annual ring then flatly rounded; the four or five ribs on the anterior area slightly terraced; those on the posterior area angular in the early stage become rounded later, the three ribs next to the gentle umbonal ridge thinner and crowded, and the last four near the posterior margin are much wider. Interradials $U$. shaped to the second annual ring, after which they become welldefined lines; interradials obsolete on the medial portion. Incrementals, fine on the umbonal area, coarse on the anterior, posterior, and on the marginal portions. Lunule of holotype small, trending downward and forward. Pseudoescutcheon present. Hinge plate low and long, with a conspicuous sinuous basal line; nymph thin and long; ligamental pit deeply incised and long. Dentition well preserved on the holotype, consists of an anterior left cardinal (2a), trapezoidal with a blunted upper end, and a posterior cardinal (4b), thin anteriorly but slightly broadening ventrally. Interior of holotype with normally incised pedal and adductor muscle scars; pallial line entire; inner margins crenulated." (hertleini)

"Shell of medium size, thick, outline nearly circular; anterior, ventral and posterior margins evenly rounded, the postero-dorsal more gently curved. Shell moderately convex, with wide umbo, greatest convexity a little above the medial point of the disk; beak prosogyrate, distinctly low, placed at about the anterior one-third. Sculpture of 24 well-rounded ribs, (poorly preserved at the beak on the holotype), consisting of 16 wide, simple ribs in the antero-medial area becoming nearly obsolete below the middle of the disk, and 8 ribs on the posterior area-3 on the weak umbonal ridge, well defined and wide, 5 at the posterodorsal margin thin, crowded, becoming obsolete $15 \mathrm{~mm}$. beyond the beak; interradials present throughout except in the medial one-third of the marginal part of the shell; incrementals faint and crowded, but fairly strong ventrally; periodic growth stages (annual rings) marked by deep incisions. Lunule small, convex, deeply inset. Pseudoescutcheon and nymph not well preserved in the holotype. Hinge low and short with a distinctly sinuous ventral margin; dentition consisting of a small, laminar right anterior cardinal (3a), a sharply triangular, curved medial cardinal (3b), and a thin right posterior cardinal (5b), not well preserved. Muscle scars and pallial line slightly incised; pedal scar somewhat more stongly defined; pallial line entire, relatively far away from the ventral margin. Inner margin with unusually deep crenulations." (oregonensis)

Holotype.-UCMP 31450; of hertleini UCMP 30415; of oregonensis CAS/SU 8009; CASG 66529.01.

Type locality._UC 7004. Ventura County, Calif. Llajas Formation, Eocene. Of hertleini UC 3990, San Diego County, Calif. Rose Canyon Shale of Hanna (1927), Eocene. Of oregonensis "Bluffs along Little River at junction with North Umpqua River, Glide, Roseburg Quad., Douglas Co., Oregon." Umpqua Group, Lookingglass Formation of Baldwin (1974), Eocene. 
Supplementary description.--"Lunule convex, deeply inset, the right twice as large as the left; lunular groove trending downward and backward. Pseudoescutcheon well defined by a wide plate delimited by a grooved line on the dorsal side. Nymph long and narrow, somewhat alate at its posterior end, at the anterior it embraces a shallowly incised groovelike ligamental pit. Hinge plate high with a sinuous basal margin; dentition of the right valve consists of a strong plate-shaped, anteriorly slightly convex anterior cardinal (3a); a scimitar-like, strongly curved medial cardinal (3b), showing an incised groove in the upper part of the anterior face; and a long, thin, cordlike posterior cardinal (5b), the left valve has a high, curved, cuneate anterior cardinal (2), with an oblique cord in the upper part of the posterior face to correspond to the groove in $3 \mathrm{~b}$; and a thin, curved posterior cardinal (4b) which slopes slightly at the ventral end. Pedal and adductor muscle scars shallowly incised, the posterior scar remote from the hinge; pallial line entire, rather near the margins. Inner margin faintly crenulated." (Verastegui, 1953, p. 28-29)

" $V$. hornii calafia is characterized by its circular to subquadrate outline and by the presence of 24 radial ribs**** (Givens, 1974, p. 47)

Comparison.- "Stewart's subspecies (calafia) differs only in small details from the rounded varieties of $V$. hornii (Gabb) found in the type Tejon. The anterior dorsal margin of the former is fuller, giving the beaks a lower appearance, and the ribs are slightly less rounded." (Turner, 1938, p. 50)

"V. lutmani Turner from the lower part of the Umpqua formation appears to be ancestor of $V$. calafia. The two species differ somewhat in outline, $V$. lutmani being more subquadrate, but the pattern of the hinge is almost identical in both." (Verastegui, 1953, p. 29-30)

"The subspecies calafia resembles the species hornii in number of ribs and ornamentation more than does the subspecies lutmani. The specimens of calafia from southwest Oregon have the radiating ribs less rounded than in the species hornii and the general outline of the shell is more orbicular than in the subspecies lutmani." (Weaver, 1942, p. 135)

Geographic range.-Southern Oregon and southern California.

Geologic range.-Eocene.

Occurrence in California.-Eocene: Llajas Formation (Keen and Bentson, 1944; Verastegui, 1953; Squires, 1984) and Rose Canyon Shale (Hanna, 1927).

\section{Venericardia (Pacificor) calafia gabbi Verastegui Plate 4, figures 2, 6, 8, 10}

Cardita planicosta Lamarck. Conrad, 1855, p. 321, pl. 2, fig. 6. Not Cardita planicosta Lamarck, 1801.

Venericardia hornii (Gabb). Hanna, 1925, p. 286-287, pl. 39, figs. 1, 2. Anderson and Hanna, 1925, p. 174, pl. 4, fig. 1.

Venericardia (Pacificor) gabbi Verastegui, 1953, p. 30-31, pl. 19, figs. $1,5,6$.

Original description.- "Shell large, thick, subquadrate in outline, the anterior margin broadly rounded, the ventral gently curved, the postero-ventral truncate, the postero-dorsal slightly arched. Umbo inflated, broadly convex, umbonal ridge inconspicuous but defined by a sudden change from coarse to fine ribs; beak prosogyrate, low, full, placed at about the anterior onefourth. Sculpture consists of 23 ribs, 8 in the anterior area, wide, terraced and beaded in typical Pacificor manner; in the medial portion 6 ribs widen ventrally away from the umbo; in the posterior portion 9 narrow ribs, the 4 nearest the cardinal margin less distinct but wider; interradials on the beak channeled, becoming linear, and persisting to the margin except in the medial-ventral area; incrementals fine in the umbonal area and coarse in the anterior and posterior portions. Lunule cordate, convex, anteriorly trending downward and slightly backward. Pseudoescutcheon distinct, wide. Hinge plate low and long; nymph triangular, long; ligamental pit elongate, deeply incised; dentition consists of a laminar anterior right cardinal (3a); a scimitar-like medial cardinal (3b) with a wide base, elongate anteriorly; and a cordlike, short posterior right cardinal (5b) on a wide nymphal body. Interior of the holotype concealed by matrix."

Holotype.-CAS 685; CASG 245.01.

Type locality.-Grapevine Canyon, Kern County, Calif. Tejon Formation, Eocene.

Supplementary description.- "Venericardia gabbi is characterized by its subquadrate outline and by its strongly convex umbo." (Verastegui, 1953, p. 30)

Comparison.- "It [gabbi] differs from V. hornii (Gabb) in its outline, as the original Gabb specimen is elongate and obliquely ovate and $V$. gabbi has a quadrate outline accentuated by a sharp truncation on the posterior ventral margin." (Verastegui, 1953, p. 30)

Geographic range.-Southern California.

Geologic range.-Eocene.

Occurrence in California.-Eocene: Tejon Formation (Verastegui, 1953).

\section{Venericardia (Pacificor) clarki clarki Weaver and Palmer Plate 5, figures 4, 6}

Venericardia planicosta Lamarck. Arnold, 1907, pl. 38, figs. 1, 1a. Arnold, 1910, p. 13, pl. 2, fig. 1. Not Venericardia planicosta Lamarck, 1801.

Venericardia planicosta hornii (Gabb). Waring, 1917, p. 95-96, pl. 11, figs. 3-5.

Venericardia clarki Weaver and Palmer, 1922, p. 19, pl. 9, figs. 4, 5; pl. 10, fig. 8. Hanna, 1925, p. 287-288, pl. 36, figs. 3, 8; pl. 38, figs. 2, 3; pl. 43, figs. 1, 2; pl. 44, figs. 1, 2.

Venericardia hornii subsp. clarki Weaver and Palmer. Turner, 1938 , p. 49 (in part), pl. 14, figs. 3,5 . Weaver, 1942, p. 274, pl. 27, figs. 7, 9, 10, 17; pl. 33, fig. 6 .

Venericardia (Pacificor) weaveri Verastegui, 1953, p. 31, pl. 21, figs. 3, 4.

Venericardia (Pacificor) lisa Verastegui, 1953, p. 39, pl. 21, figs. $1,2$.

Venericardia (Pacificor) hornii (Gabb). Givens, 1974, p. 46, pl. 3, fig. 3.

Original description.--"Shell small and ovate; umbones small; anterior end slightly produced, sloping from the beaks at an angle of $20^{\circ}$, rounding into the ventral margin; ventral margin regularly rounded; posterior end rounded, passing from the ventral margin at about the same degree of convexity as the anterior end; surface ornamented with 18 to 20 very well developed radiating ribs with rounded interspaces about half the width of the rib; the median portion of the ribs is raised and rounded, the base forming a lower ridge on each side of the ribs, giving them a tripartite character; the median, raised portion of the ribs is ornamented by fine nodes or pustules which occur on all the ribs on very young shells, and on the umbonal region and the anterior end of most of the shells; the ribs on the posterior end of the older specimens become broader and the pustulate condition obliterated; inner margin fluted." (clarki)

"Shell large, thick, outline round to subquadrate, the anterior and ventral margins evenly rounded, the postero-ventral somewhat attenuate and the posterior margin slightly truncate. Umbo convex, inflated; umbonal ridge weak, ribs narrower on posterior slope; beak distinctly low, at about the anterior 
two-fifths. Sculpture, characteristic of Pacificor, consisting of 21 rounded ribs relatively less perceptible in the ventral portion of the medial area; 14 ribs in the antero-medial area typically fasciculate-tripartitely ribbed-showing a distinct nodose ornamentation near the beak and on rib crests; 7 ribs in the posterior area less prominent, thin and crowded. Interradials persistent to the margins, V-shaped on the beaks, become linear in the rest of the shell. Incrementals fine on the disk, coarse on the anterior portion. Lunule cordate, deeply inset; lunular groove wide, vertical. Pseudo-escutcheon well defined; hinge plate long and low with a sinuous basal margin; ligamental groove and ligamental pit deep, the latter deeply excavated. Dentition of the right valve of the holotype consists of a small, laminar anterior cardinal (3a); with a triangular, pyramidal anterior cardinal (2), and a thin, curved posterior cardinal (4b). Pedal and adductor muscle scars well incised; pallial line at a moderate distance from the margins. Inner margin with wide crenulations." (weaveri)

"Shell large, outline subquadrate to ovate, the anterior margin passing into the ventral in an evenly rounded arc, the posteroventral margin attenuate, the posterior slightly curved; umbonal region inflated; beaks low, placed at the anterior one-third. Sculpture (not well preserved in the holotype) consists of 20 to 22 simple, rounded ribs. Ribs almost obsolete in the ventral part of the medial portion of the shell, but distinct to the margin in the anterior and posterior areas. Interradials linear, evanescent in the medial portion and near the ventral area. Incrementals fine, threadlike. Lunule cordate, small; lunular groove wide, trending downward and slightly forward. Pseudoescutcheon present. Hinge plate low and long. Nymph long; ligamental pit in front of the nymph deeply incised; anterior right cardinal (3a), laminar, small; a medial (3b) strong, curved forward, with a long basal margin; a posterior cardinal (5b) thin, cordlike; the left valve with a small trigonal, elongate anterior cardinal (2) and a thin, curved posterior cardinal (4b). Pedal and adductor muscle scars small and shallowly incised. Inner margin crenulate." (lisa)

Holotype.-UW 169; of weaveri CAS/SU 8024; CASG 66530.01; of lisa CAS/SU 8023; CASG 66531.01.

Type locality.-UW 169 from the north bank of Cowlitz River, near the bend in sec. 28, T. 11 N., R. 2 W., Little Falls, Lewis County, Wash. Cowlitz Formation, Eocene; of weaveri Southeast bank of Stillwater Creek, $1 \frac{1 / 4}{4}$ miles [2 km] NW of Vader, Wash., Cowlitz Formation, Eocene.; of lisa Bluffs along Olequa Creek at Old Ainslee Mill, T. 11 N., R. 2 W., Lewis County, Wash. Cowlitz Formation, Eocene.

Supplementary description.- "The diagnostic features of $V$. weaveri are rounded to subquadrate outline, rounded ribs, and the subcuneate shape of the medial cardinal (3b)." (Verastegui, 1953, p. 30)

Comparison.- "V. weaveri***has fewer ribs (by two or three) [than V. gabbi] and ${ }^{* * *}$ the basal margin of its medial cardinal $(3 \mathrm{~b})$ is narrower. The latter difference may be due to the smaller size of the compared holotype." (Verastegui, 1953, p. 32)

Geographic range.-Washington and southern California.

Geologic range.-Eocene.

Occurrence in California.-Eocene: "questionably 'Coldwater" (Verastegui, 1953), and Gaviota (Weaver and Kleinpell, 1963) Formations.

\section{Venericardia (Pacificor) hornii (Gabb) Plate 5, figures 17, 18}

Cardita hornii Gabb, 1864, p. 174 (in part), pl. 24, fig. 157. Gabb, 1869, p. 187-188 (in part).
Venericardia hornii (Gabb). Hanna, 1925, p. 286-287 (in part), pl. 37, fig. 5; pl. 38, fig. 1; not pl. 39, figs. 1, $2(=V$. (P.) gabbi Verastegui).

Venericardia (Venericor) hornii (Gabb). Stewart, 1930, p. 165168, pl. 11, fig. 1.

Venericardia hornii clarki Weaver and Palmer. Turner, 1938, p. 49 (in part), pl. 14, fig. 1.

Venericardia hornii (Gabb) clarki Weaver and Palmer. Weaver in Weaver and Kleinpell, 1963, p. 153, pl. 32, fig. 2; pl. 27, fig. 8. Not Venericardia clarki Weaver and Palmer, 1922.

Venericardia (Pacificor) hornii (Gabb). Verastegui, 1953, p. $33-35$, pl. 18, figs. $1-7$; pl. 19, fig. 7. Givens, 1974 , p. 46-47, pl. 3, fig. 3.

Venericardia (Pacificor) lisa Verastegui. Weaver and Kleinpell, 1963 , p. 200 (in part), pl. 33, fig. 5. Not Venericardia (Pacificor) lisa Verastegui, 1953.

Original description.--"Shell large, thick, convex, subquadrate, oblique; beaks prominent, anterior, subterminal; cardinal margin broadly arched, sloping slightly, and uniting with the posterior end with a regular curve; base broadly rounded, most prominent in the middle, from which point it runs upwards rapidly towards the anterior end, which is broadly and regularly curved; posterior end obliquely subtruncated, angular below. Surface marked by twenty-two broad rounded ribs, a little the smallest posterior to the umbonal angle; these ribs are somewhat flattened above, especially towards the base, have acute interspaces, and are crossed by numerous coarse, irregular lines of growth. Hinge very thick, robust, and resembling that of $C$. [ardita] planicosta of the Eocene."

Lectotype-ANSP 4558 (Stewart, 1930).

Type locality.-Live Oak Canyon (LouElla Saul, written commun., 1989) near Fort Tejon [Kern County, Calif.]. Tejon Formation, Eocene.

Supplementary description.-- "Typical Venericardia hornii is characterized by an obliquely ovate outline, a pointed to sharply rounded posteroventral margin, and 20-22 rounded radial ribs." (Givens, 1974, p. 47)

Geographic range.-Oregon(?); southern California.

Geologic range.-Eocene.

Occurrence in California.-Eocene: Coldwater Sandstone (Givens, 1974), Gaviota (Clark and Anderson, 1938), and Tejon (Dickerson, 1915; Keen and Bentson, 1944) Formations.

\section{Venericardia (Pacificor) aragonia joaquinensis (Vokes)}

Plate 6, figures 1-10; plate 8, figure 3; plate 9, figures 17, 19

Megacardita (Venericor) hornii (Gabb) joaquinensis Vokes, 1939, p. 69-70, pl. 8, figs. 1, 2; pl. 9, figs. 1,2.

Venericardia (Leuroactis) joaquinensis (Vokes). Verastegui, 1953, p. 60-61, pl. 11, figs. 1-4; pl. 12, figs. 4-6.

Venericardia (Pacificor) aragonia joaquinensis (Vokes). Saul, 1983 , p. 76 , pl. 2, figs. $7,8$.

Venericardia ionensis Waring. Hanna, 1925, p. 42, pl. 42, figs. 1, 2. Not Venericardia ionensis Waring, 1914.

Venericardia (Leuroactis) schencki Verastegui, 1953, p. 50-51, pl. 4, figs. 6-8.

Venericardia (Leuroactis) alisoensis Verastegui, 1953, p. 52-53, pl. 10, figs. 1-3.

Megacardita (Venericor) aragonia (Arnold and Hannibal) smileyi Vokes, 1939, p. 67-68, pl. 6, figs. 1-3.

Venericardia (Leuroactis) smileyi Vokes. Verastegui, 1953, p. 5556 , pl. 10 , figs. 4,5 .

Venericardia (Leuroactis) vokesi Verastegui, 1953, p. 61-62, pl. 14, figs. 1-3. 
Original description.-_Shell large, heavy, variable in shape; umbos prominent, inflated, anterior; posterior cardinal margin convex, rounded, ventral nearly straight, anterior broadly rounded ventrally but quite sharply rounded dorsally, straightening out to the small, deeply impressed lunule; sculpture consisting of 21 subobsolete radial ribs appearing as low rounded waves on an otherwise smooth surface; hinge-plate large; posterior cardinal on the left valve long, thin, strongly curved; anterior cardinal short, thin, small; nymph-plate strong, appressed to the posterior cardinal at the anterior end."(joaquinensis)

"Shell large, thick, umbo narrow, convex, elongated diagonally and twisted forward; anterior margin evenly rounded, ventral margin slightly curved, posterior margin truncate; beak prosogyrate, at about the anterior one-third. Ribs 23, broadly rounded in the adult, in the young stage flat-topped, separated by narrow U-shaped interradials gradually becoming linear incisions; 16 ribs on the antero-medial portion, 7 compressed cordlike ribs on the posterior area, those nearest the posterior margin less discernible. Incrementals faint, distinctly wavy about $3 \mathrm{~cm}$. from the beak become more sharply defined and threadlike near the ventral margin. Lunule deeply inset, convex, bordered by a deeply incised lunular groove. Escutcheon present. Ligamental groove well defined. Hinge plate very short and high with a straight ventral margin. Anterior cardinal (3a) broken in holotype but apparently placed vertically; socket (2') unusually deep, almost vertical, curving forward; medial cardinal (3b) very prominent, somewhat twisted forward, with a short basal margin and a knife-edged upper end; socket (4b') narrow, deep throughout its length; posterior cardinal $(5 \mathrm{~b})$ wanting. Interior not well preserved; pedal muscle scar shallow; adductor muscle scars deeply incised; pallial line distant from the margin. Inner margin distinctly crenulate." (schencki)

"Shell large, heavy, with prominent umbos; posterior broadly rounded from umbo to posterior ventral edge where quite angulate, the ventral margin broadly rounded to the anterior cardinal edge, the shell there rounding sharply to the straight anterior cardinal margin; lunule small, deeply impressed; escutcheon elongate, well developed; surface with 21 rounded subobsolete ribs separated by narrow linear interspaces, the posterior 5 ribs narrower and less well developed than those on the rest of the valve; right valve of the hinge with a large trigonal and curved cardinal; left valve with a small elongate curved posterior cardinal, the posterior cardinal broad ventrally." (smileyi)

"Shell large, thick, cordate, obliquely elongate in outline; anterior and posterior margins attenuate, ventral very gently curved, and postero-dorsal gently arched. Umbo convex and umbonal ridge even less sharply defined than in $V$. joaquinensis; beak prominent, prosogyrate, placed at about the anterior one-fourth. Sculpture consisting of 22 broadly rounded ribs; 14 simple ribs well defined in the upper one-third of the shell, becoming inconspicuous and giving place to fine wavy incrementals, which become coarse with age; on the posterior area eight weak ribs, relatively more discernible than the anterior ones and traceable to the ventral margin. Interradials linear in the early part of the shell, becoming obsolete, represented over most of the shell by weakly defined shallow furrows. Lunule deeply inset, the right part three times as large as the left; lunular groove trending downward and backward. Escutcheon well defined by the hingecord. Hinge rather low and short, with a straight ventral margin; nymph narrow, long; ligamental pit shallowly incised; dentition strong, consisting in the right valve of a short, small anterior cardinal (3a); a cuneate, elongate medial cardinal (3b) slightly curved forward; and a long posterior cardinal (5b); the figured holotype (left valve) with an anterior cardinal (2) curved upward and forward, elongate and truncate at the upper end, and a curved, long and high posterior cardinal (4b). Other inner characters concealed by matrix." (vokesi)

Holotype-UCMP 15616; of schencki CAS/SU 8003, CASG 66532.01; of alisoensis UCMP 30176; of vokesi UCMP 15618; of smileyi UCMP 15626.

Type locality.-UC 4170. Kings County, Calif. Avenal Sandstone, Eocene; of schencki: About 2 miles [3 km] northeast of Simi Peak, Simi Hills, Camulos quadrangle, Ventura County, Calif. Santa Susana Shale of Verastegui (1953), Eocene; of alisoensis UC 7019, Los Angeles County, Calif. Llajas Formation, Eocene; of vokesi Two thousand feet $[610 \mathrm{~m}]$ east and 500 feet $[150 \mathrm{~m}]$ north of SW corner sec. 17, T. 23 S., R. 17 E., half a mile [1 km] east of Big Tar Canyon, Cholame quadrangle, Reef Ridge sheet, Kings County, Calif. Avenal Sandstone, Eocene; of smileyi UC 672. Fresno County, Calif. Domengine Formation, Eocene.

Supplementary description.- "The principle [sic] variation in this species is in the height-length ratio. The general features of the outline, notably the shape of the anterior and posterior ends, are constant and appear to be characteristic." (Vokes, 1939. p. 70)

Comparison.- "This subspecies may be distinguished from typical M.[egacardita] hornii (Gabb) and $M$. hornii clarki (Weaver and Palmer) by the obsolete character of the ribbing. It differs from $M$. aragonia (Arnold \& Hannibal) in being less angulate at the posterior ventral margin, more sharply rounded anteriorly, and in having lower, more massive umbos. It differs from other described forms of Megacardita in both shape and character of ribbing." (Vokes, 1939, p. 70)

Comments.-Venericardia (Pacificor) aragonia aragonia (Arnold and Hannibal) does not occur in the Californias; it is restricted to Oregon.

Geographic distribution.-Middle and southern California.

Geologic distribution.-Paleocene and Eocene.

Occurrence in California.-Eocene: Avenal Sandstone (Kappeler and Squires, 1984), Domengine (Vokes, 1939) and Llajas (Squires, 1983; Saul, 1983) Formations, Muir Sandstone (Weaver, 1953), and Santa Susana Shale (Verastegui, 1953).

\section{Venericardia (Pacificor) clarki popenoei Verastegui Plate 9, figure 7, 15}

Venericardia (Leuroactis) popenoei Verastegui, 1953, p. 62-63, pl. 22, figs. 1-3.

Venericardia (Pacificor) lisa Verastegui. Weaver and Kleinpell, 1963, p. 200 (in part), pl. 33, figs. 4, 7.

Original description.- "Shell large, thick, subquadrate in outline, with an almost horizontal antero-dorsal margin; the anterior margin evenly rounded toward the ventral margin; the antero-dorsal end sharply rounded to subangular. Umbonal convexity perceptibly flattening toward the anterior margin. Beak prosogyrate, low, placed at about the anterior one-third. Sculpture ${ }^{* * *}$ consists of 21 ribs, simple, flat-topped in the early stage, then rounded until the shell is $35-40 \mathrm{~mm}$. high, and finally become almost obsolete; differentiated as follows: 14 ribs on the antero-medial portion and 7 ribs in the posterior area, not so wide, but slightly more conspicuous. Interradials Ushaped on the tip of the umbo, become linear and gradually disappear, their position still marked by the wavy pattern of incrementals. Growth lines or incrementals distinct in the holotype, fine in the young stage but become coarse with age. Lunule of holotype (left valve) narrow and high; lunular groove well incised, trending downward and forward. Escutcheon present and distinctly defined by the escutcheonal cord. Ligamental groove 
wide and deep. Nymph thin and short; ligamental pit long, incised and rough. Hinge plate rather short and low with an almost straight ventral margin. Dentition (left valve) consists of a bean-shaped anterior left cardinal (2) isolated from the lunular arch, a triangular socket $\left(3 b^{\prime}\right)$ wide to accommodate a large trigonal cardinal ( $3 \mathrm{~b})$ (a distinctive character of this subspecies), and a thin, high posterior cardinal (4b) slightly broadened ventrally. Pedal muscle scar small, adductor muscle scars shallowly incised. Pallial line entire, distant from margin, apparently represented by a band of transverse rugosities. Inner margins crenulate."

Holotype.-UCMP 15689.

Type locality.-UCLA-581. "East side of main branch of Sespe Gorge, Ventura Co., California." "Coldwater" Formation, of Verastegui (1953) Eocene.

Supplementary description.-The ribs are noded, sharply angled, and probably tripartite, but abrasion and recrystallization on the holotype have obscured details (LouElla Saul, written commun., 1989).

Comparison. $-V$. popenoei can be distinguished from $V$. joaquinensis by the slight concavity in the anterior area of the shell and by the wider trigonal socket. (Verastegui, 1953)

"Venericardia (P.) popenoei is proportionately higher than $V$. $(P$.$) joaquinensis and has fewer ribs" (LouElla Saul, written com-$ mun., 1989).

Geographic range.-Southern California.

Geologic range.-Eocene.

Occurrence in California.-Eocene: "Coldwater" (Verastegui, 1953), Sacate (Weaver and Kleinpell, 1963) Formations; Eocene and Oligocene: Gaviota Formation (Weaver and Kleinpell, 1963; Verastegui, 1953).

\section{Subgenus VENERICOR Stewart, 1930}

Obliquely subtrigonal; immature ribs angular and spaced evenly, in adults flat and low, approximate, and finally vanishing; lunule depressed.

Geographic range.-Europe, North America.

Geologic range.-Paleocene and Eocene.

Comments.-Figure 3 shows the phylogeny of Venericor in the eastern Pacific.

\section{Venericardia (Venericor) venturensis Waring}

Plate 8, figures 1, 2, 4, 5, 7, 9, 11, 14

Venericardia planicosta venturensis Waring in McLaughlin and Waring, 1914, map folio, fig. 12. Waring, 1917, p. 80, pl. 11, figs. $6,7,9$.

Venericardia venturensis Waring. Hanna, 1925, p. 284, pl. 37, figs. 1-4. Stewart, 1930 , p. 165 . Schenck and Keen, 1950, pl. 19 , fig. 5 .

Venericardia (Venericor) venturensis Waring. Keen and Bentson, 1944 , p. 120 . Verastegui, 1953 , p. $45-47$, pl. 3, figs. 1-4; pl. 4, fig. 5. Zinsmeister, 1983, pl. 1, fig. 21.

Venericardia (Venericor?) venturensis Waring. Saul, 1983, p. 79, appendix 2, pl. 1, fig. 4 [explanation for plate in error].

Venericardia (Venericor) simiana Verastegui, 1953, p. 47-48, pl. 4, figs. 1-4.

Original description.- "Shell large, thick, cordate, deeply convex, altitude greater than the length; beaks large, turned forward, nearly touching; lunule small; anterior cardinal margin deeply excavated in angle; posterior cardinal margin deeply grooved and broadly convex; posterior margin convexly truncate; surface ornamented by 25-30 large, square shouldered ribs, which are strong clear to the margins, with deep squared interspaces; posterior ribs narrow and indistinct; entire surface marked by wrinkled lines of growth. Locality 4, L.S.J.U. Pal. Coll." (venturensis)

"Shell large, thick, cordate in outline, anterior margin broadly rounded, the ventral gently curved, sharply rounded at the postero-ventral end, passing into truncated posterior; umbones slightly convex; posterior area set off both by the umbonal ridge and by the difference in sculpture; beaks low, at about the anterior one-fourth. Ribs $28-30 ; 19$ in the antero-medial area persistent, V-shaped at beaks flat-topped throughout the surface of the disk and separated by $U$-shaped interradials. Lunule deeply set, convex, pointing downward and backward, bordered anteriorly by a lunular groove; in the left valve the lunular groove ends in a pustule corresponding to a small depression on the right valve. Escutcheon not defined. Wide ligamental groove and elongated nymph, with a deep triangular ligamental pit at its anterior end. Hinge heavy, low, long, with a distinctly sinuous basal margin; dentition strong and prominent; right anterior cardinal (3a) laminar, vertical, minute; a middle cardinal ( $3 b$ ) curved, scimitar-like, with a dorsal edge sharply grooved ventrally; posterior cardinal (5b) thin, almost undifferentiated; paratype No. 8002 with an elongate, cuneate left anterior cardinal (2) and a high, thin, posterior (4b). Pedal scars small; adductor muscle scars concealed by matrix in all specimens examined; pallial line remote from the strongly crenulate margin." (simiana)

Holotype.-CAS/SU 159; CASG 61667.08; of simiana CAS/SU 8001; CASG 66533.01.

Type locality.-SU 2697. Ventura County, Calif. Santa Susana Formation of Zinsmeister (1983), Paleocene; of simiana SU 2697, Ventura County, Calif. Santa Susana Formation, Paleocene.

Comparison.- "Venericardia venturensis Waring may easily be distinguished from other Eocene Venericardia of the West Coast by its greater altitude in proportion to its length, and by the squareness of the radial ribs; it may be distinguished from $V e$ nericardia ionensis Waring by the radial ribs usually extending to the basal margin. All the individuals referred to this species have been found associated with Martinez fossils." (Hanna, 1925, p. 284)

Geographic range.-Middle California to Baja California Norte.

Geologic range.-Paleocene.

Occurrence in California.-Paleocene: Santa Susana Formation (Waring, 1917; Kew, 1924; Verastegui, 1953; Zinsmeister, 1983).

\section{Venericardia (Venericor) vallecitosensis (Vokes) Plate 2, figures 3-5, 7}

Megacardita (Venericor) vallecitosensis Vokes, 1939, p. 67, pl. 5, figs. 10-12.

Venericardia (Pacificor) vallecitosensis (Vokes). Verastegui, 1953, p. $35-36$, pl. 12, figs. 1-3.

Megacardita (Venericor) hornii (Gabb) carlosensis Vokes, 1939, p. 68-69, pl. 7, figs. 1-6.

Venericardia (Venericor) carlosensis (Vokes). Verastegui, 1953, p. $36-37$, pl. 13, figs. 4-9.

Original description.--Shell large, heavy, almost circular in outline; umbos moderately inflated; surface with 23 radiating ribs, those on the central portion of the valve being planicostate and separated by flat-bottomed interspaces about two thirds as wide as the ribs; valve slightly angulate at the sixth rib from the posterior margin, the posterior ribs narrow, somewhat ridged 
and closer together, the anterior 5 or 6 ribs so interrupted by the growth-lines as to appear to be noded, and separated by interspaces wider than the ribs; growth-lines elsewhere on the shell not prominent; lunule small and inconspicuous; hinge-plate small, the central cardinal of the left valve comparatively small, trigonal in shape and somewhat posterior to the umbo; socket large, curved on both the anterior and posterior sides; posterior cardinal long, thin, and high; nymph-plate thin, high, so close to the posterior cardinal as to suggest a deeply grooved tooth."

"Shell moderately large, thin for the genus, variable in shape, quadrate to subtrigonal; umbos small, anterior; lunule minute, deeply impressed; escutcheon narrow, elongate; posterior end of shell obliquely angulate; surface with 21 radial ribs, the posterior 5 ribs small, rounded and weakly developed, separated by interspaces of equal width; the 3 ribs anterior to these strongly developed, persistently flat-topped, angulate at the edges, and separated by V-shaped interspaces of equal width; the 5 anterior ribs nodose in appearance due to the strength of the growthlines and separated by interspaces of equal width; the 8 ribs on the center of the valve minutely nodose in the early stages of development, flat-topped during adolescence, and rounded in the adult; hinge-plate small, the right cardinal curved, narrow and elongate, the nymph-plate long and grooved, the right socket narrow and obliquely set with a small tubercle on the anterior side; the left anterior cardinal small and subtriangular, the posterior cardinal long, thin, and curved, the nymph-plate long, low, and so closely set against the posterior cardinal as to appear to be a part of that tooth." (carlosensis)

Holotype.-UCMP 15614; of carlosensis UCMP 15619.

Type locality.-UC A-1022. San Benito County, Calif. Domengine Formation, Eocene; of carlosensis UC A-1017. Top of a small ridge $800^{\prime}$ [244 $\mathrm{m}$ ] SW of Hill 2,200 near center of south edge of sec. 16, T. 17 S., R. 12 E., Priest Valley quadrangle, San Benito County, Calif. Domengine Formation, Eocene.

Supplementary description. - "The number of ribs is constant: of 40 specimens examined 4 had 20 ribs, 27 had 21,8 had 22 , and 1 had 23. This form occurs at but one locality*** where it is associated with Pelecyora aequilateralis (Gabb), Ostrea idriaensis Gabb, Loxotrema turrita Gabb, Potamides carbonicola Cooper, and Calyptraea diegoana (Conrad). These species suggest that the water was of less than normal salinity, which may be a possible explanation for the thin shell and the great variation in shape." (Vokes, 1939, p. 69)

Comparison.- "The small umbo and general outline is very suggestive of Gabb's original figure of M.[egacardita] hornii, but the small hinge-plate with the narrow elongate right cardinal, and the character of the ribbing are distinctive." (Vokes, 1939, p. 69)

Geographic range.-Middle California.

Geologic range.-Eocene.

Occurrence in California.-Eocene: Domengine Formation (Vokes, 1939; Keen and Bentson, 1944).

\section{Subfamily CARDITESINAE Genus GLYPTOACTIS Stewart, 1930}

Short trapezoidal, with high nodulose or echinate ribs; small, irregularly convex lunule extending under and slightly behind beaks.

Geographic range.-North America, Europe, Africa.

Geologic range.-Cretaceous to Miocene.

Comments.-Figure 3 shows the phylogeny of Glyptoactis in the eastern Pacific.

\section{Subgenus CLAIBORNICARDIA Stenzel and Krause, 1957}

More developed on both sides and with lower beaks than Glyptoactis (Glyptoactis); ribs triparite, posteriorly echinate; lunule less depressed.

Geographic range.-North America, Europe.

Geologic range.-Paleocene to Eocene.

Comments.-Figure 3 shows the phylogeny of Claibornicardia in the eastern Pacific.

\section{Glyptoactis (Claibornicardia) sandiegoensis (Hanna) Plate 1, figures 15, 19, 21; plate 7, figs. 15, 22}

Cardita sandiegoensis Hanna, 1927, p. 283, pl. 37, figs. 1, 2, 8, 9. Venericardia sandiegoensis (M. Hanna). Stewart, 1946, table 1. Glyptoactis (Claibornicardia) sandiegoensis (Hanna, 1927). Givens and Kennedy, 1979, p. 95, table 1. Squires, 1987, p. 64 , fig. 110 .

Venericardia (Glyptoactis) mcmastersi Verastegui, 1953, p. 4243, pl. 13, figs. $2,3$.

Original description.- -Shell of moderate size, elongate-ovate; ventral margin broadly regularly rounded; anterior more sharply rounded; posterior obliquely truncated to slightly rounded; dorsal straight to slightly rounded; beak moderately prominent; surface concentrically striated by distinct growth lines; radially striated by fifteen to nineteen prominent ribs; posterior ribs rather sharp, separated by sharply rounded interspaces; the posterior ribs are only slightly terraced on either side; terracing becomes more prominent on the anterior half of the shell, so much so that the anteriormost ribs are nearly three separate ribs, each group of three ribs wider and separated by narrower shallow interspaces; from the beak to the posterior ventral point the shell is ventricose, less ventricose both to the anterior and to the posterior of this line; inner margin deeply crenulate; hinge plate narrow, typically carditiform. Dimensions. Cotype 30983: Altitude $33 \mathrm{~mm}$., length $45 \mathrm{~mm}$." (sandiegoensis)

"Shell small, quadrate in outline, anterior margin evenly rounded, the ventral slightly curved, the posterior distinctly truncated, making an angle of $90^{\circ}$ with the ventral margin; postero-ventral and postero-dorsal ends sharply rounded to subangular, accentuating the quadrate outline of the shell. Umbo strongly inflated, curved forward, prosogyrate, with beak placed at about the anterior one-fourth. Umbonal ridge, delimiting the posterior area, defined by the change in the coarseness of the ribs. Sculpture similar to that of $V$. keenae, n. sp., consisting of 21 well-developed ribs; 4 simple crowded ribs on the anterior portion followed on the medial portion by 9 ribs definitely terraced on both sides; 8 ribs on the posterior area simple, $V$ shaped; the crest of the ribs bears fine nodes which are conspicuous on the ventral area of the valve. Interradials Ushaped. Incremental sculpture fine. Lunule small, semicordate, trending forward and downward, with deeply incised lunular groove. Escutcheon narrow. Hinge plate low and long, with an arched ventral margin. Nymph thin; ligamental pit inconspicuous. Dentition consisting of pustule-like anterior left cardinal (2), broken off in the holotype; and a slender, long posterior cardinal (4b). Pallial line entire, closely placed to the margin. Inner margin strongly crenulate." (mcmastersi)

Types.-Syntypes UCMP 30980-30983; holotype of mcmastersi CAS/SU 8011; CASG 66534.01. 
Type locality.-UC 5062. San Diego County, Calif. Rose Canyon Shale of Hanna (1927), Eocene; of mcmastersi San Clemente Canyon, San Diego Co., California. La Jolla Group, Eocene.

Comments.-Stewart $(1930$, p. 152) suggested that sandiegoensis might be a Glyptoactis.

Geographic range.-Middle and southern California.

Geologic range.-Eocene.

Occurrence in California.-Eocene: Avenal Sandstone (Stewart, 1946), Delmar Sand and Rose Canyon Shale (Hanna, 1927), and Juncal Formation (Squires, 1987).

\section{Glyptoactis (Claibornicardia) keenae (Verastegui) Plate 8, figures 6, 8, 10, 12, 13, 15}

Venericardia (Glyptoactis) keenae Verastegui, 1953, p. 41-42, pl. 1, figs. 1-5. Smith, 1975, p. 470, pl. 2, fig. 5.

Venericardia (Pacificor) argentea Verastegui, 1953, p. 25-26, pl. 1, figs. 10-14.

Original description.- "Shell small, cordate-subquadrate in outline, anterior and ventral margins broadly rounded, the posterior truncated and the dorsal margin slightly arcuate; umbo strongly convex with the most prominent point above and slightly anterior to the mid-point of the disk; posterior area sharply delineated by a change in sculpture and radially depressed; beak prosogyrate, low and compact. Sculpture distinct, consisting of 30 ribs persistent throughout the entire surface of the shell; of these, the 4 anterior ribs crowded, thin, faintly fasciculate, (slightly terraced); the next 14 ribs conspicuously terraced, so that they appear to be tripartite with a central crest bordered on each side by smaller riblets (the central crest beaded with light funnel-shaped tubercules not discernible upon ribs of the umbonal area); the succeeding 4 ribs with a terraced face only on the posterior side; posterior area with 4 crowded Vshaped ribs; the remaining 4 ribs a little wider, with riblets on the posterior side. Interspaces at the anterior and posterior portions V-shaped; in the medial area, with deep U-shaped channels. Incrementals fine and sharp, more noticeable on the posterior area of the adult shell. Lunule small, distinctly convex, bounded by an incised lateral groove which in the left valve ends ventrally, with the walls of the trough forming a knob (the anterior pustule of Stewart). Escutcheon slightly discernible, bordered below by a cord. Ligamental groove narrowly incised. Nymph narrow and elongate. Ligamental pit not evident. Hinge plate low and short with a straight ventral border; dentition of the left valve consists of a nearly trigono-pyramidal anterior cardinal (2), isolated from the lunular plate; and a thin posterior cardinal (4b) broadens toward the ventral end. Pedal muscle scar small and shallowly incised; adductor muscle scars moderately incised, pallial line entire and remote from the ventral margin. Inner margins crenulate."

"Shell of medium size, inflated-ovate in outline with the ventral margin broadly rounded, umbones prominent, greatest inflation a little above the center of the disk the surface rounds off broadly in all directions, except toward the posterior slightly concave dorsal slope; beak prosogyrate, low and compact, placed at about the anterior one-third. Ribs 30 to 32; typical Pacificor sculpture (as described in the diagnosis of the subgenus). Posterior area with 10 ribs; the 5 th nearest the dorsal margin wide, with one posterior riblet; the other 5 thin, crowded, V-shaped, with corresponding V-shaped interspaces. Interspaces in the medial portion squarely channeled, one-third the width of the ribs. Frontal rib crests show a beadlike appearance as in $V$. mulleri. Lunule small, convex, sloping forward, (not well preserved in the holotype). Pseudoescutcheon present. Ligamental groove deeply incised; nymph long and wide; ligamental pit shallowly incised. Hinge plate low and short; dentition of the left valve with a strongly developed, scimitar-like anterior cardinal (2), projected over the medial plane, and a thin posterior cardinal (4b) which thickens gradually toward the ventral end. Pedal muscle scars normally incised. Adductor muscle scars and pallial line concealed by matrix." (argentea)

Holotype.-CAS/SU 7992; CASG 66535.01; of argentea CAS/SU 7995; CASG 66535.02.

Type locality.-SU 2073. Fresno County, Calif. Base of Lodo Formation, Paleocene; for argentea the same.

Geographic range.-Middle California.

Geologic range.-Paleocene.

Occurrence in California.-Paleocene: Basal part of the Lodo Formation (Verastegui, 1953; Smith, 1975).

\section{Glyptoactis (Claibornicardia) marksi (Verastegui) Plate 7, figures 17, 19}

Venericardia (Glyptoactis) marksi Verastegui, 1953, p. 44, pl. 19, figs. 2-4.

Original description.--"Shell small, thin, outline subcircular, the anterior and ventral margins evenly rounded, the posteroventral truncated, the postero-dorsal slightly arched. Umbo fairly convex, prominent, with the greater inflation in the middle of the disk; beak prosogyrate, heavy, full, placed at about the anterior two-fifths. Sculpture consists of 18 ribs strongly ornamented by fine closely spaced beads along the crests; of these the 5 in the anterior area thin, simple, separated by wide $U$ shaped interspaces twice as wide as the ribs; the 8 medial ribs simple in the early umbonal area, but become terraced (tripartite) in the mature part of the shell; interspaces wide, U-shaped; the 5 ribs on the posterior area closely spaced and thin with interspaces V-shaped; incrementals fine, more visible on the flatbottomed interspaces. Lunule small, convex. Escutcheon wanting. Hinge rather high for the subgenus; dentition of the right valve consists of a small anterior cardinal (3a), a cuneate long medial cardinal ( $3 b)$, and a slender posterior cardinal (5b). Interior of the holotype concealed by matrix except for the inner margin, which is strongly crenulate."

Holotype.-CAS/SU 8021; CASG 66536.01.

Type localilty._SU 183. "East side of Live Oak Canyon, Kern Co., California." Live Oak Member of the Tejon Formation of Verastegui (1953), Eocene.

Comparison.-“***V. marksi can be readily distinguished from $V$. domenginica by its heavier and less pointed beak, by its circular outline, and by the greater convexity of the shell." (Verastegui, 1953)

Geographic range.-Southern California.

Geologic range.-Eocene.

Occurrence in California.--Eocene: Cozy Dell Formation (Weaver and Kleinpell, 1963) and Live Oak Member, Tejon Formation of Verastegui, 1953.

\section{Glyptoactis (Claibornicardia) domenginica (Vokes) Plate 7, figures 10, 12, 13, 16, 18, 20}

Venericardia (Glyptoactis?) domenginica Vokes, 1939, p. 66, pl. 5, figs. 7-9.

Venericardia (Glyptoactis) domenginica Vokes. Verastegui, 1953, p. 43 , pl. 13, fig. 1 .

Glyptoactis domenginica (Vokes). Givens, 1974, p. 47. 
Glyptoactis (Glyptoactis) domenginica (Vokes, 1939). Squires, 1984, p. 46-47, figs. 10q-r. Squires, 1987, p. 63-64, fig. 109.

Glyptoactis (Claibornicardia) domenginica (Vokes, 1939). Squires, 1988, p. 19, fig. 50.

Original description.- "Shell small, moderately inflated, inequilateral, almost circular in outline; umbo small, high, prominent; lunule impressed; sculpture consisting of 17 radial, ridged, strongly beaded ribs, separated by round-bottomed interspaces slightly more than half as wide as the ribs, the ribs being finer and closer together on the posterior portion of the valve; posterior cardinal of the hinge in the right valve long, slender, curved, the anterior cardinal in the left valve reduced to a small rugosity bounding the anterior end of the large central socket, with a well-defined anterior lateral pustule."

Holotype.-UCMP 15611.

Type locality.-UC A-1219. Fresno County, Calif. Domengine Formation, Eocene.

Supplementary description.- "This species is more typical of the subgenus Claibornicardia Stenzel and Kraus (in Stenzel et al., 1957) than of the subgenus Glyptoactis Stewart (1930). Heaslip $(1968: 98,110)$ compared these two subgenera and reported that only Claibornicardia had spinose ribs, and that it lacked the diagnostic 'tooth' that Glyptoactis had above the intersection of the lunule and the anterior point of the left posterior cardinal tooth. Glyptoactis (Claibornicardia) domenginica has spinose radial ribs and lacks the diagnostic 'tooth'." (Squires, 1988, p. 19.)

"****the specimens show the diagnostic 16 to 17 noded tripartite ribs that are finer and closer together on the posterior portion of the valve. The tripartite nature of the ribs also becomes less apparent posteriorly. "(Squires, 1988, p. 19)

Comparison.- " $V$. domenginica differs from all the described western Eocene species referred to the Carditidae in size, shape, and character of the ribbing. It finds its nearest analogue in the group of $V$. acuticostata in the Lutetian-Bartonian of France." (Vokes, 1939, p. 66)

Geographic range.-Middle and southern California.

Geologic range.-Eocene.

Occurrence in California.-Eocene: Domengine, Llajas, and Tejon Formations (Vokes, 1939); Juncal(?) Formation (Squires, 1988).

\section{Subfamily THECALIINAE Genus MILNERIA Dall, 1871}

Narrowly trapeziform, very inequilateral, with two median posterior angulations, finely echinate ribs, concentric lines; beaks orthogyrous.

Geographic range.-Middle California to Baja California Sur.

Geologic range.-Pliocene to Holocene.

Habitat.-Intertidally to $27 \mathrm{~m}$, byssate and nestles on flat surfaces like the backs of Haliotis (Hertlein and Grant, 1972, p. 240); intertidally to $80 \mathrm{~m}$ (Bernard, 1983).

\section{Milneria minima (Dall) Plate 9, figures 16, 18}

Ceropsis minima Dall, 1871, p. 152, pl. 16, figs. 5, 6.

Milneria minima Dall. Hertlein and Grant, 1972, p. 234, pl. 43, figs. 1, 2, 14. Coan, 1977, p. 384.

Original description.- "Shell minute, trapeziform, white, with a thin brownish epidermis. Umbones prominent, nearly terminal. Anterior margin rather strongly angulated; basal margin straight, or a little concave; lower posterior extremity angulated; upper posterior angle rounded off; posterior margin rather oblique. Hinge line smooth, rather broad. Ligament conspicuous, moderately long. A rounded carina passes from the umbo to the lower posterior angle, above which are from two to five radiating ribs. General sculpture of sharp elevated lines of growth, which become vaulted scales on the ribs. Margin lightly crenulated. Interior polished; muscular and pallial impressions indistinct. Long. 14, lat. 08., alt. .175 in."

Lectotype.-USNM 63349 (Coan, 1974).

Type locality,- "Habitat, nestling or burrowing in Haliotis rufescens, at Monterey, also dead on beach."

Comparison.- "The major radial ribs on $M$. minima are rather coarse and are about equal in size, whereas those on $M$. kelseyi are finer and less coarsely scaled. The umbonal and one or more of the other ribs are higher than the rest. Furthermore the lunule of $M$. kelseyi is smaller and the escutcheon larger than that of $M$. minima. Milneria kelseyi attains a greater size than $M$. minima, up to $8 \mathrm{~mm}$ long***." (Hertlein and Grant, 1972, p. 234)

Geographic range.-Living: Monterey, Calif., to Isla de Natividad, Baja California Sur.

Geologic range.-Pliocene to Holocene.

Occurrence in the Californias.-Pliocene: San Diego Formation (Hertlein and Grant, 1972); Pleistocene: unnamed strata in the Palos Verdes Hills, San Pedro, Calif. (Woodring and others, 1946), and on San Nicolas Island (Vedder and Norris, 1963).

Habitat.-Intertidally to $80 \mathrm{~m}$ in the eastern Pacific (Bernard, 1983). Attaches to hard substrates by a byssus (Coan, 1977).

\section{FOSSIL LOCALITIES}

[Corrections and information not in the original description are in brackets: feet and miles are converted to the metric system, formations are cited as emended by later workers, where pertinent.]

California Academy of Sciences:

CAS 65. West bank of a small canyon $2 \mathrm{~km} \mathrm{NE}$ of Barker's Ranch House [SE 1/4, sec. 32, T. 28 S., R. 29 E., Caliente quadrangle], Kern County, Calif. Temblor Formation.

CAS 244. In east bank of Live Oak Creek, $1.2 \mathrm{~km}$ from mouth, $4.8 \mathrm{~km}$ due east of mouth of Grapevine Canyon, Tejon quadrangle, Kern County, Calif. Tejon Formation.

Los Angeles Natural History Museum:

LAM $305.730 \mathrm{~m}$ east and $310 \mathrm{~m}$ south of NW cor. sec. 8, T. 19 S., R. 2 W., S.B.M., San Ysidro quadrangle, 1943 ed. [San Diego County], Calif. San Diego Formation.

LAM 305c. Hills south of Tijuana River at Palm City, Calif. "K" Ranch, exactly $290 \mathrm{ft}$ [88m] from the U.S.-Mexican border fence. Southwest of Goat Canyon, at base of hill $100 \mathrm{ft}[31 \mathrm{~m}] \mathrm{W} ., 440 \mathrm{ft}[134 \mathrm{~m}] \mathrm{S}$. of NE cor. sec. 8. Imperial Beach quadrangle, San Diego County, Calif. San Diego Formation.

Stanford University [These collections are now all in the California Academy of Sciences]:

SU 2073. Road cut just south of middle of section line between secs. 20 and 29 , in sec. 29, T. 15 S., R. 12 E., opposite junction of Panoche and Silver Creeks, Panoche quadrangle, Fresno County, Calif. Basal part of Lodo Formation.

SU 2696. McCray wells [Oil Canyon, 3 miles [5km] north $20^{\circ}$ east of B.M. 961 at Santa Susana, Santa Susana quadrangle, Ventura County, Calif.]. Llajas Formation.

SU 2697. Simi Hills, [4.5 km ENE of Simi Peak, near head of east fork of Las Virgenes Canyon], Camulos quadrangle, Ventura County, Calif. Santa Susana Formation. 
University of California at Berkeley:

UC 672. South part of crest of Parson's Peak, SE1/4, N1/4, sec. 24, T. 18 S., R. 14 E., Coalinga quadrangle, Fresno County, Calif. Domengine Formation.

UC 2033. South of Hill 651 about $400 \mathrm{~m}, 800 \mathrm{~m}$ west of Kirkers Creek, near west edge sec. 30, T. 2 N., R. 1 E., Mt. Diablo quadrangle, Contra Costa County, Calif. Kirker Tuff, Oligocene.

UC 3765. NW $1 / 4 \mathrm{SW}^{1 / 4}$ sec. 24 , T. 2 N., R. 18 W., $2,060 \mathrm{~m} \mathrm{E}$ of Hill 2150, Simi Hills, Camulos quadrangle, Ventura County, Calif., Martinez Group of Dickerson (1914); Santa Susana Formation of Zinsmeister (1983).

UC 3990. On the east side of canyon in bottom of Rose Creek, $485 \mathrm{~m}$ east of " $\mathrm{t}$ " of "Soledad Mountain," La Jolla quadrangle, San Diego County, Calif.

UC 4170. West side of Big Tar Canyon, T. 23 S., R. 17 E., Cholame quadrangle, Kings County, Calif. Avenal Sandstone.

UC 5062. In sea cliff south of mouth of Soledad Valley, due west of midpoint between "P" and " $u$ " of "Pueblo," La Jolla quadrangle, San Diego County, Calif.

UC 7004. Branch of Las Llajas Canyon just north of northernmost extent of 1,500-foot contour, Simi Valley (Santa Susana quadrangle), Ventura County, Calif. Llajas Formation.

UC 7019. West side of Aliso Canyon West, beds striking northwest and dipping west. Fossils occur in narrow lenses. Elev. $555 \mathrm{~m}$. Los Angeles County, Calif.

UC A-1219. West side, near top of long ridge extending northwest of Hill 2126, on line between secs. 9 and 16, T. 19 S., R. 15 E., Coalinga quadrangle, Fresno County, Calif. Domengine Formation.

UC A-1022. $300 \mathrm{ft}$. [90 m] above mouth and $20 \mathrm{ft}$. [6 m] up north wall of small canyon entering San Carlos Creek, south edge of sec. 16, T. 17 S., R. 12 E., Priest Valley quadrangle [San Benito County, Calif.]. Domengine Formation, Eocene.

UC A-1233. West of Roseburg, Douglas County, Oreg. Umpqua Formation.

UC A-3582. Bahía Santa Inez, from 6-m terrace level extending from locality UC A-3581 to beach. Baja California Sur.

UC A-3670. Puerto Balandra, Isla Carmen, from sands at left end of outcrop and below base of coral reef, Baja California Sur.

\section{GEOLOGIC FORMATIONS CITED FOR OCCURRENCE OF PELECYPODS}

\section{Family Erycinidae through Carditidae}

\author{
Name \\ Age \\ California: \\ Avenal Sandstone -.............-- Eocene. \\ Capistrano -...-..-- Miocene and Pliocene. \\ Cebada Member, Careaga \\ Sandstone -.-.-.-.-.-.-Pliocene. \\ Cerros Shale Member, Lodo \\ Formation -.........-.....-..-.-Paleocene. \\ Coal Canyon Formation -.--.--Paleocene.
}

Coldwater Sandstone or

"Coldwater" Formation -..-- Eocene.

Cozy Dell Formation

or Shale -..-...-...-Eocene.

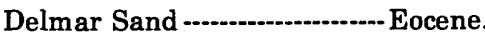

Dip Creek Formation ----------Late Cretaceous and Paleocene.

Domengine Formation or

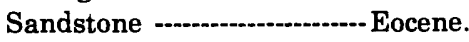

Elk River Formation ----.-.---.--Pleistocene.

Fernando Formation -........... Pliocene and Pleistocene.

Foxen Mudstone -................ Pliocene.

Gaviota Formation -..---.----- Eocene and Oligocene.

Graciosa Member, Careaga

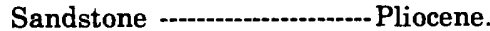

Juncal Formation -.-.-.-.------Eocene.

Kirker Tuff -.-.-.-.-.-.-.-- Oligocene.

La Jolla Formation or

Group -..-..-.-.-.-.-Eocene.

Live Oak Member, Tejon

Formation -...-..-.-.-Eocene.

Llajas Formation ------------Eocene.

Lodo Formation -......-...-..-.-Paleocene and Eocene.

Lomita Marl Member,

San Pedro Formation -........ Pleistocene.

Martinez Formation

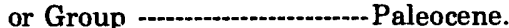

Meganos Formation ............. Paleocene and Eocene.

Monterey Shale -.-.-.-.-.-.-. Miocene.

Muir Sandstone -..........-.......- Eocene.

Pancho Rico Formation -------Miocene.

Pico Formation -.............-..--.-Pliocene and Pleistocene.

Rio Dell Formation -............-. Pliocene and Pleistocene.

Rose Canyon Shale -..-...-.---.-Eocene.

Round Mountain Silt -..--..---Miocene.

Sacate Formation .......------Eocene.

San Diego Formation ---.-.-.-- Pliocene.

San Francisquito

Formation -.............-...-Paleocene.

San Pedro Formation

or Sand -...-..-..-Pleistocene.

Santa Barbara Formation ---Pliocene and Pleistocene.

Santa Susana Shale or

Formation --.-.-.-Paleocene and Eocene.

Saugus Formation ---.--.--.-. Pliocene and Pleistocene.

Sisquoc Formation -.......-...-.-Miocene and Pliocene.

Tejon Formation -..............-. Eocene.

Timms Point Silt Member, San

Pedro Formation .............. Pleistocene.

Towsley Formation -.-.--------Miocene and Pliocene.

Baja California peninsula:

Bateque Formation -............. Paleocene(?), Eocene

Comondú Formation -........... Pliocene.

Marquer Formation -.---.--.--- Pliocene.

Oregon:

Cowlitz Formation ---.-----.-----Eocene.

Umpqua Formation

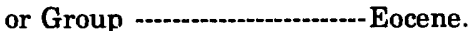

Washington:

Cowlitz Formation -.....-.---.--Eocene.

Stratigraphic nomenclature used is that of the references cited in the text and does not necessarily accord with that of the U.S. Geological Survey. 


\section{REFERENCES}

Abbott, R.T., 1974, American Seashells [2d ed.]: New York, Van Nostrand Reinhold, 663 p., 24 pls.

Addicott, W.O., 1966, Late Pleistocene marine paleoecology and zoogeography in central California: U.S. Geological Survey Professional Paper 523-C, p. C1-C21, 4 pls.

-1976, Neogene molluscan stages of Oregon and Washington: Neogene Symposium, Pacific Section, Society of Economic Paleontologists and Mineralogists Meeting, San Francisco, California, p. 95-115, 5 pls.

Anderson, F.M., and Hanna, GD., 1925, Fauna and stratigraphic relations of the Tejon Eocene at the type locality in Kern County, California: California Academy of Sciences Occasional Papers 11, 249 p., 16 pls.

Anderson, F.M., and Martin, Bruce, 1914, Neocene record in the Temblor Basin, California, and Neocene deposits of the San Juan District, San Luis Obispo County: California Academy of Sciences Proceedings, ser. 3, v. 4, p. 15-112, pls. 1-10.

Arnold, Ralph, 1903, The paleontology and stratigraphy of the marine Pliocene and Pleistocene of San Pedro, California: California Academy of Sciences Memoirs, v. 3, 419 p., $37 \mathrm{pls}$. -1907 , New and characteristic species of fossil mollusks from the oil-bearing Tertiary formations of southern California: Smithsonian Miscellaneous Collection, v. 50, no. 4, p. $419-447$, pls. $50-58$.

1908, Descriptions of new Cretaceous and Tertiary fossils from the Santa Cruz Mountains, California: U.S. National Museum Proceedings, v. 34, no. 1617, p. 345-402, pls. 31-37.

Baldwin, E.M., 1974, Eocene stratigraphy of southwestern Oregon: Oregon Department of Geology and Mineral Industries, Bulletin 83, $40 \mathrm{p}$.

Bernard, F.R., 1979, Bivalve mollusks of the western Beaufort Sea: Natural History Museum of Los Angeles County, Contributions in Science no. 313, 80 p., 112 figs.

-1983, Catalogue of the living Bivalvia of the Eastern $\mathrm{Pa}$ cific Ocean: Bering Strait to Cape Horn: Canadian Special Publication of Fisheries and Aquatic Sciences 61, $102 \mathrm{p}$.

Broderip, W.J., and Sowerby, G.B., 1832-1833, Characters of new genera and species of Mollusca and Conchifera, collected by Mr. Cumming: Zoological Society of London Proceedings for 1832 , p. 25-33, 50-61, 104-108, 124-126, 173-179, 194-202.

Carpenter, P.P., 1864, Supplementary report on the present state of our knowledge with regard to the Mollusca of the west coast of North America: British Association for the Advancement of Science for 1863 , p. 517-686.

1865, Diagnoses of new forms of Mollusca, from the west coast of North America, first collected by Col. E. Jewett: Ann. Magazine of Natural History, series 3, v. 15, p. 177-182.

Clark, B.L., 1918, The San Lorenzo Series of middle California: University of California Publications, Bulletin of the Department of Geology, v. 11, no. 2, p. 42-234, pls. 3-24.

Coan, E.V., 1974, Is there double trouble in marsupial clams?: The Veliger, v. 17, no. 2, p. 183-184, 1 pl.

- 1977, Preliminary review of the northwest American Carditidae: The Veliger, v. 19, no. 4, p. 375-386, 19 figs.

Conrad, T.A., 1855, Descriptions of eighteen new Cretaceous and Tertiary fossils: Academy of Natural Sciences of Philadelphia Proceedings, v. 7, p. 265-268.

1857, Description of the Tertiary fossils collected on the survey (Williamson's survey), in Reports of explorations and surveys*** railroad ${ }^{* * *}$ from the Mississsippi River to the $\mathrm{Pa}$ cific Ocean: U.S. 33d Congress, 2d sess., Senate Executive Document 78 and House Executive Document 91, v. 6, pt. 2, p. 69-73, pls. 2-5. (Reprinted in Dall, 1909, U.S. Geological Survey Professional Paper 59, p. 176-179.)

Dall, W.H., 1871, Descriptions of sixty new forms of mollusks from the west coast of North America and the North Pacific Ocean, with notes on others already described: American Journal of Conchology, v. 7, pt. 2, p. 93-160, pls. 13-16.

1874 , Notes on some Tertiary fossils from the California coast, with a list of the species obtained from a well at San Diego, California, with descriptions of two new species: California Academy of Sciences Proceedings, v. 5, p. 296-299.

-1899 , Synopsis of the recent and Tertiary Leptonacea of North America and the West Indies: U.S. National Museum Proceedings, v. 21 , no. 1177 , p. $873-897$.

-1903a, Contributions to the Tertiary fauna of Florida with especial reference to the Miocene silex-beds of Tampa and the Pliocene beds of the Caloosahatchie River: Wagner Free Institute of Science of Philadelphia Transactions, v. 3, pt. 6, p. 1219-1654, pls. 48-60.

1903b, Synopsis of the Carditacea and of the American species: Academy of Natural Sciences of Philadlphia Proceedings, v. 54, p. 696-716.

Deshayes, G.P., 1839, Nouvelles espèces de mollusques, provenant des côtes de la California, du Mexique, du Kamtschatka et de la Nouvelle-Zelande: Revue zoologique, par la Société Cuvierienne, v. 2, p. 356-361.

Dickerson, R.E., 1914, Fauna of the Martinez Eocene of California: University of California Publications, Bulletin of the Department of Geology, v. 8, no. 6, p. 61-180, pls. 6-18.

1915, Fauna of the type Tejon: Its relation to the Cowlitz phase of the Tejon group of Washington: California Academy of Sciences Proceedings, ser. 4, v. 5, no. 3, p. 33-98, pls. 1-11.

1916, Stratigraphy and fauna of the Tejon Eocene of California: University of California Publications, Bulletin of the Department of Geology, v. 9, no. 17, p. 363-524, pls. 36-46.

Durham, D.L., and Addicott, W.O., 1965, Pancho Rico Formation, Salinas Valley, California: U.S. Geological Survey Professional Paper 525-A, p. A1-A22, 5 pls.

Durham, J.W., 1950, Megascopic paleontology and marine stratigraphy, in 1940, E.W. Scripps Cruise to the Gulf of California, pt. II: Geological Society of America Memoir 43 , p. $1-216,48$ pls.

Eldridge, G.H., and Arnold, Ralph, 1907, The Santa Clara Valley, Puente Hills, and Los Angeles oil districts, southern California: U.S. Geological Survey Bulletin 309, 266 p., pls. 25-41.

Emerson, W.K., and Hertlein, L.G., 1964, Invertebrate megafossils of the Belvedere Expedition to the Gulf of California: San Diego Society of Natural History Transactions, v. 13, no. 17 , p. $333-368$.

Flynn, J.J., Cipolletti, R.M., and Novacek, M.J., 1989, Chronology of early Eocene marine and terrestrial strata, Baja California, Mexico: Geological Society of America Bulletin, v. 101, p. 1,182-1,196, 10 figs., 6 tbls.

Gabb, W.M., 1861, Description of new species of American Tertiary fossils and a new Carboniferous cephalopod from Texas: Academy of Natural Sciences of Philadelphia Proceedings, v. 13, p. $367-372$.

1864, Description of the Cretaceous fossils: California Geological Survey, Paleontology, v. 1, sec. 4, p. 55-243, pls. 9-32. 1869, Tertiary invertebrate fossils: California Geological Survey, Paleontology, v. 2, Cretaceous and Tertiary fossils, sec. 1,2 , pt. 2, p. $1-254,36$ pls.

Givens, C.R., 1974, Eocene molluscan biostratigraphy of the Pine Mountain area, Ventura County, California: University of California Publications in Geological Sciences, v. 109, 107 p., 11 pls. 
Givens, C.R., and Kennedy, M.P., 1979, Eocene molluscan stages and their correlation, San Diego area, California, in Abbott, P.L., ed., Eocene depositional systems, San Diego, California: Los Angeles, Pacific Section, Society of Economic Paleontologists and Mineralogists, Field Trip Guide, Geological Society of American Annual Meeting, p. 81-95, figs. 1-6, tables 1-4.

Gould, A.A., 1850, (Shells collected by the U.S. Exploring Expedition under the command of Charles Wilkes): Boston Society of Natural History Proceedings, p. 276-278.

-1852, Mollusca and shells, in U.S. Exploring Expedition during the years 1839-1842 under the command of Charles Wilkes, v. 12,510 p., atlas.

Grant, U.S., 4th, and Gale, H.R., 1931, Catalogue of the marine Pliocene and Pleistocene Mollusca of California and adjacent regions: San Diego Society of Natural History Memoir, v. 1, 1,036 p., 32 pls.

Gray, J.E., 1825, A list and description of some species of shells not taken notice of by Lamarck: Annals of Philosophy, new series, v. 9, p. 134-140; 407-415.

Hanna, M.A., 1925, Notes on the genus Venericardia from the Eocene of the West Coast of North America: University of California Publications, Bulletin of the Department of Geological Sciences, v. 15 , no. 8, p. 281-306, pl. 36-44.

-1927, An Eocene invertebrate fauna from the La Jolla quadrangle, California: University of California Publications, Bulletin of the Department of Geological Sciences, v. 16 , no. 8 , p. 247-398, pls. 24-57.

Hertlein, L.G., and Grant, U.S., 4th, 1972, The geology and paleontology of the marine Pliocene of San Diego, California (Paleontology: Pelecypoda): San Diego Society of Natural History Memoir 2, pt. 2B, 409 p., pls. 28-57.

Hertlein, L.G., and Strong, A.M., 1946, Mollusks from the west coast of Mexico and Central America, pt. III, in Eastern Pacific expeditions of the New York Zoological Society: Zoologica, New York, v. 31, p. 93-120, pl. 1 .

Jones, G.F., 1963, Brood protection in three southern Californian species of the pelecypod genus Cardita: Wasmann Journal of Biology, v. 21, p. 141-148.

Jordan, E.K., 1926, Molluscan fauna of the Pleistocene of San Quintin Bay, Lower California: California Academy of Sciences Proceedings, 4th ser., v. 15, no. 7, p. 241-255, pl. 25.

Kanakoff, G.P., and Emerson, W.K., 1959, Late Pleistocene invertebrates of the Newport Bay area, California: Natural History Museum of Los Angeles County Contributions in Science No. 31,47 p., 5 figs.

Kappeler, K.A., and Squireś, R.L., 1984, Transgressive marginalmarine deposits of the Avenal Sandstone, Reef Ridge, Central California, in Blueford, J.R., ed., Kreyenhagen Formation and related rocks: Society of Economic Paleontologists and Mineralogists, Pacific Section, p. 9-27.

Keen, A.M., 1938, New pelecypod species of the genera Lasaea and Crassinella: Malacological Society of London Proceedings, v. 23, pt. 1, p. 18-32, pl. 2.

1943, New mollusks from the Round Mountain Silt (Temblor) Miocene of California: San Diego Society of Natural History Transactions, v. 10 , no. 2, p. 25-60, pls. 3-4.

1971, Sea shells of tropical West America (2d ed.): Stanford, Calif., Stanford University Press, 1,064 p., 3,305 figs.

Keen, A.M., and Bentson, Herdis, 1944, Check list of California Tertiary marine Mollusca: Geological Society of America Special Paper 56, $280 p$

Keen, A.M., and Coan, E.V., 1974, Marine molluscan genera of western North America: an illustrated key (2nd ed.): Stanford, Calif., Stanford University Press, 208 p.
Kern, J.P., 1973, Early Pliocene marine climate and environment of the eastern Ventura basin, southern California: University of California Publications in Geological Sciences, v. 96, 117 p., 27 figs.

Kern, J.P., and Wicander, E.R., 1974, Origin of a bathymetrically displaced marine invertebrate fauna in the upper part of the Capistrano Formation (lower Pliocene), southern California: Journal of Paleontology, v. 48, no. 3, p. 495-505.

Kew, W.S.W., 1924, Geology and oil resources of a part of Los Angeles and Ventura Counties, California: U.S. Geological Survey Bulletin 753, $202 \mathrm{p}$.

Krause, A., 1885, Beitrag zur Kenntniss der Mollusken-Fauna des Beringsmeeres: Archiv Naturgeshichte, v. 541, Branchiopoda und Lamellibranchiata, p. 14-40, pl. 3.

MacGinitie, Nettie, 1959, Marine Mollusca of Point Barrow, Alaska: United States National Museum Proceedings, v. 109, p. 59-208, $27 \mathrm{pls}$.

McLaughlin, R.P., and Waring, C.A., 1914, Petroleum industry of California: California Mining Bureau Bulletin 69, $510 \mathrm{p}$.

Moore, R.C., ed., 1969, Treatise on invertebrate paleontology: Geological Society of America and Kansas University, pt. N, Mollusca, v. 1 and 2, 952 p., illus.

Morris, R.H., Abbott, D.P., and Haderlie, E.C., 1980, Intertidal invertebrates of California: Stanford, Calif., Stanford University Press, 690 p., 200 pls.

Nelson, R.N., 1925, A contribution to the paleontology of the Martinez Eocene of California: University of California Publications, Bulletin of the Department of Geological Sciences, v. 15 , no. 11, p. $397-466,13$ pls.

Nelson, R.N., 1925, A contribution to the paleontology of the Martinez Eocene of California: University of California Publications, Bulletin of the Department of Geological Sciences, v. 15 , no. 11, p. $397-466,13$ pls.

Oldroyd, I.S., 1924, The marine shells of Puget Sound and vicinity: University of Washington Publication, Puget Sound Biological Station, v. 4, 272 p., 49 pls.

Olsson, A.A., 1961, Mollusks of the tropical eastern Pacific: Ithaca, N.Y., Paleontological Research Institute, 547 p., 86 pls.

Olsson, A.A., and Harbison, Anne, 1953, Pliocene Mollusca of southern Florida with special reference to those from north Saint Petersburg: Academy of Natural Sciences of Philadelphia Monograph 8, p. 1-304, 63 pls.

Palmer, K.V.W., 1958, Type specimens of marine Mollusca described by P.P. Carpenter from the West Coast: Geological Society of America Memoir 76, 376 p., 35 pls.

Roth, Barry, 1979, Late Cenozoic marine invertebrates from northwest California and southwest Oregon: Doctoral Dissertation, University of California at Berkeley, 789 p., 11 pls.

Rowland, R.W., 1972, Paleontology and paleoecology of the San Diego Formation in northwestern Vaja California: San Diego Society of Natural History Transactions, v. 17, no. 3, p. 25-32.

Sakamoto, Kenji, 1973, Techniques for photographing modern mollusks: The Veliger, v. 16, no. 2, p. 140-142, 1 pl

Saul, L.R., 1983, Notes on Paleogene turritellas, venericardias, and molluscan stages of the Simi Valley area, California in Squires, R.L., and Filewicz, M.V., eds., Cenozoic geology of the Simi Valley area, southern California: Society of Economic Paleontologists and Mineralogists, Pacific Section, Los Angeles, Calif., p. 71-80, 2 pls.

1986, Mollusks of latest Cretaceous and Paleocene age, Lake Nacimiento, California, in Grove, Karen, and Graham, Stephen, eds., Los Angeles, Calif., U.S.A., Society of Economic Paleontologists and Mineralogists, Pacific Section, p. 25-31. 
Schenck, H.G., and Keen, A.M., 1940, California fossils for the field geologist: Stanford, Calif., Stanford University Press, 88 p., 56 pls.

Smith, A.G., and Gordon, Mackenzie, Jr., 1948, The marine mollusks and brachiopods of Monterey Bay, California, and vicinity: California Academy of Sciences Proceedings, 4th ser. v. 26 , no. 8 , p. $147-245$, pls. 3,4 .

Smith, J.T., 1975, Age, correlation, and possible Tethyan affinities of mollusks from the Lodo Formation of Fresno County, California, in Weaver, D.W., Hornaday, G.R., and Tipton, Ann, eds., Paleogene symposium and selected technical papers, Conference on future energy horizons of the Pacific Coast: American Association of Petroleum Geologists, Society of Economic Paleontologists and Mineralogists, and Society of Economic Geologists, Annual Meeting, Pacific Sections, Long Beach, Calif., p. 464-483, 2 pls.

Soper, E.K., and Grant, U.S., 4th, 1932, Geology and paleontology of a portion of Los Angeles, California: Geological Society of America Bulletin, v. 43, no. 2, p. 1,041-1,068, 7 figs.

Soot-Ryen, Tron, 1951, Antarctic pelecypods, in Holtedahl, Olaf, ed., Scientific Results of the Norwegian Antarctic Expeditions 1927-1928 ET SQQ., instituted and financed by Consul Lars Christensen, v. 3, 46 p., 1 pl.

Squires, R.L., 1983, Eocene Llajas Formation, Simi Valley, southern California, in Squires, R.L., and Filewicz, M.V., eds., Cenozoic Geology of the Simi Valley area, southern California: Society of Economic Paleontologists and Mineralogists, Pacific Section, Fall Fieldtrip volume and guide book, p. 81-96.

1984, Megapaleontology of the Eocene Llajas Formation, Simi Valley, California: Natural History Museum of Los Angeles County Contributions in Science no. 350, 76 p., 19 figs.

-1987, Eocene molluscan paleontology of the Whitaker Peak area, Los Angeles and Ventura Counties, California: Natural History Museum of Los Angeles County, Contributions in Science, no. 388, 93 p., 135 figs.

1988, Eocene macropaleontology of northern Lockwood Valley, Ventura County, California: Natural History $\mathrm{Mu}-$ seum of Los Angeles County, Contributions in Science, no. 398,23 p., 55 figs.

Squires, R.L., and White, D.R., 1983, Common megafossils of the lower Saugus Formation, northern Simi Valley, California, in Squires, R.L., and Filewicz, M.V., eds., Cenozoic Geology of the Simi Valley area, southern California: Society of Economic Paleontologists and Mineralogists, Pacific Section, Fall Fieldtrip volume and guide book, p. 221-224.

Stanley, S.M., 1970, Relation of shell form to life habits of the Bivalvia (Mollusca): Geological Society of America Memoir 125,296 p., $40 \mathrm{pls}$.

Stearns, R.E.C., 1890, Scientific results of exploration by the U.S. Fish Commission Steamer Albatross. No. XVII, Descriptions of new West American land, fresh-water, and marine shells, with notes and comments: Proceedings of the U.S. National Museum, v. 13, no. 813, p. 205-225, pls. 15-17.

Stewart, R.B., 1930, Gabb's California Cretaceous and Tertiary type Lamellibranchs: Philadelphia Academy of Natural Sciences Special Publication 3, 314 p., 17 pls.

1946, Geology of Reef Ridge, Coalinga district, California: U.S. Geological Survey Professional Paper 205-C, p. 81-115, pls. 9-17.
Taliafero, N.L., 1944, Cretaceous and Paleocene of Santa Lucia Range, California: American Association of Petroleum Geologists Bulletin, v. 28, no. 4, p. 449-521.

Turner, F.E., 1938, Stratigraphy and Mollusca of the Eocene of western Oregon: Geological Society of America Special Papers no. 10, 130 p., 22 pls.

Valentine, J.W., 1956, Upper Pleistocene Mollusca from Potrero Canyon, Pacific Palisades, California: San Diego Society of Natural History Transactions, v. 12, no. 10, p. 181-205, pl. 13. 1959, Pleistocene molluscan notes, II. A faunule from Huntington Beach Mesa, California: Nautilus, v. 73, no. 2, p. 51-57.

Valentine, J.W., and Meade, R.F., 1961, California Pleistocene paleotemperatures: University of California Publications in Geological Sciences, v. 40, no. 1, p. 1-46, 4 figs.

Valentine, J.W., and Roland, R.R., 1969, Pleistocene invertebrates from northwestern Baja California del Norte, Mexico: California Academy of Science Proceedings, 4th ser. v. 36, no. 17, p. 511-530, 5 figs.

Vedder, J.G., 1960, Previously unreported Pliocene Mollusca from the southeastern Los Angeles basin [California] in Geological Survey research 1960: U.S. Geological Survey Professional Paper 400-B, p. B326-B328.

Vedder, J.G., and Norris, R.M., 1963, Geology of San Nicolas Island, California: U.S. Geological Survey Professional Paper $369,65 \mathrm{p}$.

Verastegui, Pedro, 1953, The pelecypod genus Venericardia in the Paleocene and Eocene of western North America: Palaeontographica Americana, no. 25, 112 p., 22 pls.

Vokes, H.E., 1939, Molluscan faunas of the Domengine and Arroyo Hondo Formations of the California Eocene: New York Academy of Sciences Annuals, v. 38, p. 1-246, pls. 1-22.

Waring, C.A., 1914, Eocene horizons of California: Journal of Geology, v. 22, no. 8, p. 782-785.

1917, Stratigraphic and faunal relations of the Martinez to the Chico and Tejon of southern California: California Academy of Sciences Proceedings, 4th ser., v. 7, no. 4, p. 41124 , pls. 7-16.

Weaver, C.E., 1942, Paleontology of the marine Tertiary formations of Oregon and Washington: University of Washington (Seattle) Publications in Geology, v. 5, pt. 1, p. 1-274.

1953, Eocene and Paleocene deposits at Martinez, California: Washington University (Seattle) Publications in Geology, v. 7, 102 p., pls. $1,2$.

Weaver, C.E., and Palmer, K.V.W., 1922, Fauna from the Eocene of Washington: University of Washington (Seattle), Publications in Geology, v. 1, no. 3, p. 1-56.

Weaver, D.W., and Kleinpell, R.M., 1963, Mollusca from the Turritella variata Zone, in Kleinpell, R.M., and Weaver, D.W., Oligocene biostratigraphy of the Santa Barbara Embayment, California: University of California Publications in Geological Sciences, v. 43, pt. 2, 250 p., 38 pls.

Willett, George, 1946, Additional notes on the Pliocene molluscan fauna of Los Angeles city (California): Southern California Academy of Sciences Bulletin, v. 45, pt. 1, p. 28-32.

Woodring, W.P., and Bramlette, M.N., 1950, Geology and paleontology of the Santa Maria district, California: U.S. Geological Survey Professional Paper 222, 185 p., 23 pls., 9 figs.

Woodring, W.P., Bramlette, M.N., and Kew, W.S.W., 1946, Geology and paleontology of the Palos Verdes Hills, California: U.S. Geological Survey Professional Paper 207, 145 p., 37 pls.

Yonge, C.M., 1951, Studies on Pacific Coast mollusks, VI. A note on Kellia laperousii (Deshayes): University of California Publications in Zoology, v. 55, no. 11, p. 451-453, fig. 1. 
- 1969, Functional morphology and evolution within the Carditacea (Bivalvia): Malacological Society of London Proceedings v. 38 , no. 6 , p. $493-527,25$ figs.

Yonge, C.M., and Thompson, T.E., 1976, Living marine mollusks: William Collins Sons, London, 288 p., 16 pls., 162 figs.

Zinsmeister, W.J., 1970, A late Pliocene macrofossil fauna of Newport Beach, Orange County, California: Southern
California Academy of Sciences Bulletin, v. 69, p. 121-125. 1983, Late Paleocene ("Martinez provincial Stage") molluscan fauna from the Simi Hills, Ventura County, California, in Squires, R.L., and Filewicz, M.V., eds., Cenozoic geology of the Simi Valley area, southern California: Society of Economic Paleontologists and Mineralogists, Pacific Section, Los Angeles, Calif., p. 61-70, 4 pls. 



\section{INDEX}

[Italic page numbers indicate major references to accepted taxa]

Abbott, R.T., cited, 4, 10

quoted, 9

Acknowledgments,

acuticostata, Venericardia, 28

Addicott, W.O., cited, 14

aequata, Aligena

nuca, 8

aequilateralis, Pelecyora, 26

affinis, Byssomera (Byssomera), 5

Cardita, 11

(Byssomera), $I I ; \mathrm{pl} .9$

Carditamera (Byssomera), 11

Glans, 15

alaskana, Venericardia (Cyclocardia), 14

Aligena, 5,7

aequata nuca, 8

(Aligena) diegoana, 5, 7; pl. 1

cerritensis, 8

diegoana, 7,8

laevis, 8

(Aligena), Aligena

diegoana, 5,$7 ; \mathrm{pl} .1$

alisoensis, Venericardia (Leuroactis), 23; pl. 6

Anderson, F.M., quoted, 6

aragonia, Megacardita, 24

Venericardia, 19

(Pacificor), 27; pl. 8

aragonia, 18, 24

diabloensis, $17,18,20 ; \mathrm{pl} .5$

joaquinensis, 17, 18, 23; pls. 6, 8,9

(Venericor)

smileyi, 23

Avenal Sandstone, 24, 27

Bahía San Quintin, 6

barbarensis, Cardita, 15

Cyclocardia, 15

(Cyclocardia), 12,15; pl. 5

Venericardia, 13, 15

Basterotella, 10

Basterotella), Basterotia

hertleini, 5, 10; pl. 9

Basterotia, 5, 10

(Basterotella) hertleini, 5, 10, pl. 9

californica, 10

ecuadoriana, 10

hertleini, 10

peninsulare, 11

Bateque Formation, 20, 21

Bentson, Herdis, cited, 1

Bemard, F.R., cited, 4, 6, 7, 9, 10, 11, 12, 14, 15, 16 ,

borealis, Cardita

crebricostata, 14

Venericardia, 13

Bornia, 5,8

(Temblornia)

frankiana, 5, 8; pl. 3

triangulata, 5, 8; pl.

Bramlette, M.N., cited, 13

quoted, 15

Byssomera, II

(Byssomera)

Byssomera

affinis, 5

Cardita

affinis, $11 ; \mathrm{pl} .9$

Carditamera
affinis, 11

\section{C}

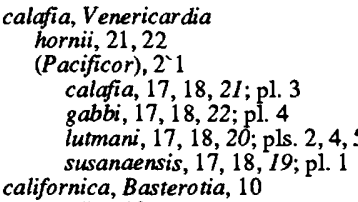

Cyclocardia, 13

Cyclocardia), 12,13; pl. 7

Venericardia (Cyclocardia), 13

Calyptraea

diegoana, 26

Capistrano Formation, 6, 15

Cardita, 4, 5, 1

affinis, 11

barbarensis, 15

borealis crebricostata, 14

(Byssomera) affinis, 5, 11; pl. 9

californica, 13

(Cardita) superioris, $5, I I ;$ pl. 4

hornii, 23

megastropha, 12

occidentalis, 13

planicosta, 22

sandiegoensis, 26

(Strophocardia) megastropha, I2; pl. 7

superioris, 11

veneriformis, 16

ventricosa, 14

"Cardita"veneriformis, 16

(Cardita), Cardita

superioris, 5,11 ; pl. 4

Carditamera (Byssomera) affinis, 1

Carditesinae, 26

Carditidae, 1, 11, 28

Cardium kikerensis, 12

Careaga Sandstone, 7, 9, 13, 15, 16

carlosensis, Megacardita (Venericor) hornii, 25

Venericardia (Pacificor) hornii, 32

Venericor (Venericor), 25

Carpenter, P.P., quoted, 15

catacta, Kellia, 5, 6, 7, 31

Cebada Member, 7, 13, 15, 16

Centrocardita, IS

(Centrocardita), Glans

veneriformis, 12,16; pl. 7

Ceropsis minima, 28

cerritensis, Aligena, 8

Cerros Shale Member, 6

chironi, Kellia laperousii, 7

Chironia

laperousii, 7

suborbicularis laperousii, ?

cistula, Lasaea, 6

Claibornicardia 18,28

(Claibornicardia) Glyptoactis

domenginica, 17, 18, 27, 28; pl. 7

keenae, $17,18,27 ; \mathrm{pl} .8$

marksi, 17, 18, 27, pl.

mcmastersi, pl. 7

sandiegoensis, 17, 18, 26; pls. 1,7

clarki, Megacardita hornii, 24

Venericardia, 22, 23

hornii, 22, 23

(Pacificor)

clarki, 17, 18, 22; pl. 5 popenoei, $17,18,24$; pl. 9

Coal Canyon Formation, 19

Coan, E.V., cited, 10, 14, 15, 16, 28 quoted, 15

Coldwater Formation, 23, 25

Sandstone, 23

Comondú Formation, 10, 11, 13

compressa, Erycina (Pseudopythina), 10

Neaeromya (Orbitella), 5,$10 ; \mathrm{pl} .4$

"Orbitella" 10

Pseudopythina, 10

conspicua, Stenoplax, 9

Corbula

Cuneocorbula) swiftiana harrisi, 6 harrisi, 6, 7

uvasana, 6

Cowlitz Formation 23

Cozy Dell Formation, 27

crebricostata Cardita borealis, 14

Cyclocardia, 14

(Cyclocardia), 12, 14; pl. 7,9

crescentensis, Venericardia (Pacificor), 18

(Cuneocorbula), Corbula

swiftiana harrisi, 6

Cyclocardia 4, 12

barbarensis, 15

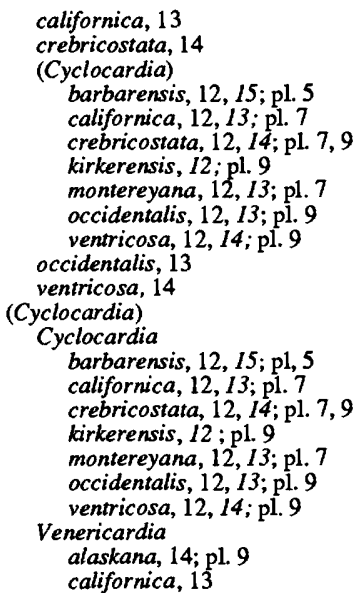

californica, 13

crebricostata, 14

(Cyclocardia)

barbarensis, 12,$15 ; \mathrm{pl} .5$

californica, 12, 13; pl. ?

crebricostata, 12, 14; pl. 7, 9

kirkerensis, 12 ; pl.

montereyana, 12, 13; pl. 7

occidentalis, 12, 13; pl. 9

ventricosa, 12,$14 ; \mathrm{pl} .9$

occidentalis, 13

ventricosa, 14

(Cyclocardia)

Cyclocardia

barbarensis, 12, 15; p1, 5

californica, 12,13; pl.7

crebricostata, 12, I4; $\mathrm{pl} .7,9$

kirkerensis, 12 ; 1.9

montereyana, 12,13; pl. 7

occidentalis, 12,$13 ; \mathrm{pl} .9$

ventricosa, 12,$14 ; \mathrm{pl} .9$

Venericardia

alaskana, $14 ; \mathrm{pl} .9$
californica, 13

D

Delmar Sand, 27

diabloensis, Venericardia (Pacificor), 20, 32 aragonia, 17, 18,20; pl. 5

diegoana, Aligena, 7,8

(Aligena), 5, 7; pl. 1

Calytraea, 26

Dip Creek Formation, 17

Domengine Formation, 24, 26, 28

domenginica

Glyptoactis, 27

(Claibornicardia), 17, 18, 27, 28; pl. 7

Glyptoactis), 28

Venericardia, 27, 28

(Glyptoactis), 27

(Glyptoactis?), 27

Donax triangulata, 8

Durham, J.W., cited, 4, 11, 12

quoted, 11

durhami, Venericardia (Pacificor), 20; pl. 2

E

ecuardoriana, Basterotia, 10

Elk River Formation, 15

Emerson, W.K., cited, 11, 12

Erycina (Pseudopythina) compressa, 10

Erycinidae, 1, 5

F

Fernando Formation, 13, 14, 15, 16

Fossil localities, 28

Foxen Mudstone, 13,16

frankiana, Bornia (Temblornia), 5,8; pl. 3

G

gabbi, Venericardia, 22, 23

(Pacificor), 22

calafia, 17, 18, 22; pl. 4

Gale, H.R., quoted, 15

Gaviota Formation, 23, 25

Geologic Formations, pelecypods in, 29

Glans, 12, I5

affinis, 11

(Centrocardita) veneriformis, 12, 16; pl. 7

(Glans) subquadrata, 12, 15; pl. 5

minuscula, 15

subquadrata, 15

(Glans), Glans

subquadrata, 12,$15 ; \mathrm{pl} .5$

Glyptoactis, 4, 17,

(Claibornicardia)

domenginica, 17, 18, 27, 28; p1.

keenae, 17, 18, 27; pl. 8

marksi, 17, 18, 27; pl. 7

mcmastersi; pl. 7

sandiegoensis, 17, 18, 26; pl. 1, 7

domenginica, 27 


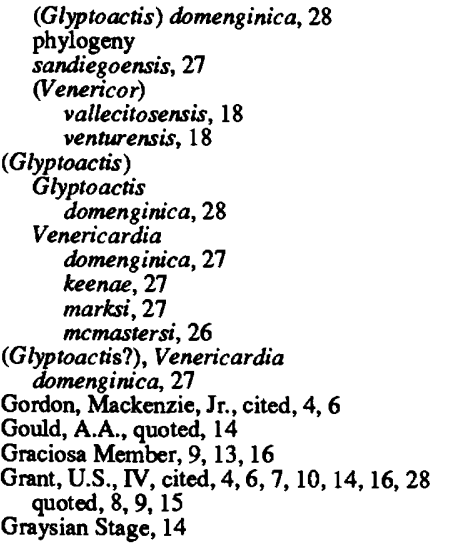

\section{H}

Haliotis rufescens, 28

Hanna, GD., quoted, 6

harrisi, Corbula, 6,7

(Cuneocorbula) swiftiana, 6

Hertlein, L.G., cited, 4, 6, 7, 10, 11, 12, 14, 16, 28 quoted, 8, 9, 16

hertleini, Basterotia, 10

Basterotia (Basterotella), 5, 10; pl.9

Venericardia (Pacificor) $21 ; \mathrm{pl} 3$

hornit, Cardita, 23

Megacardita, 24

clarki, 24

(Venericor)

carlosensis, 25

joaquinensis, 23

Venericardia

calafia, 21,22

clarki, 22, 23

lutmani, 20,21

planicosta, 22

(Pacificor) 17, 18, 20, 22, 23; p1. 5

carlosensis; pl. 2

lutmani, 20

susanaensis, 19
(Venericor), 23

I

Introduction, 1

ionensis, Venericardia, 23, 25

Isla San Martín, 6

J

joaquinensis, Megacardita (Venericor) hornii, 23 Venericardia, 24, 25

(Leuroactis), 23

(Pacificor) aragonia, 17, 18, 23; pls. 6, 8,9

Jones, G.F., cited, 14, 15

Juncal Formation, 21, 27

$\mathbf{K}$

Keen, A.M, cited, 1, 4, 6, 10, 11, 12 quoted, 8,10

keenae, Glyptoactis (Claibornicardia), 17, 18, 27

pl. 8

Kellia, 5,6

catacta, $5,6,7 ;$ pl. 1
lajollaensis, $5,6,7 ;$ pl. 3

laperousii, 5,$7 ; \mathrm{pl} .3$

rotunda, 7

suborbicularis, 7

uvasana, $5,6,7 ;$ pl. 3

Kelliidae, 1, 6

kelseyi, Milneria, 28

Kirker Tuff, 13

kirkerensis, Cardium, 12

Cyclocardia (Cyclocardia), 12; p1. 9

L

La Jolla Group, 27

laevis, Aligena, 8

lajollaensis, Kellia, 5, 6, 7; pl. 3

laperousii, Chironia, 7

suborbicularis, 7

Kellia, 5, 7; pl. 3

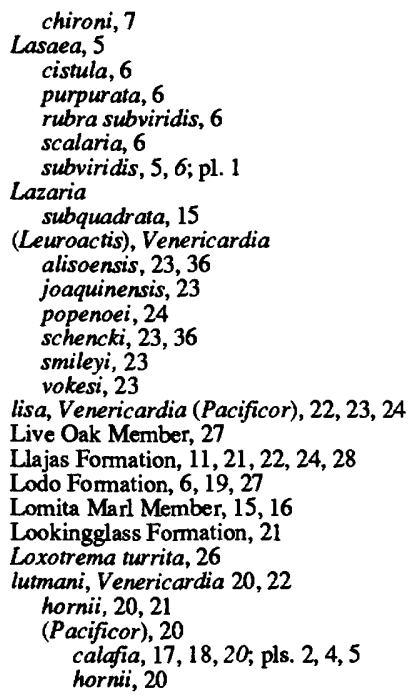

$\mathbf{M}$

marksi, Glyptoactis (Claibornicardia), 17, 18,27;

Venericardia, $27^{\mathrm{pl} .} 7$

(Glyptoactis), 27

Marquer Formation, 11, 12, 13

Martinez Formation, 19

mcmastersi, Glyptoactis (Claibornicardia); pl. 7

Venericardia (Glyptoactis), 26

Megacardita, 24

aragonia, 24

hornii, 24

clarki, 24

(Venericor)

aragonia smileyi, 23

hornii

carlosensis, 25

joaquinensis, 23

vallecitosensis, 25

Meganos Formation, 20

megastropha, Cardita, 12

Cardita (Strophocardia), 12; pl. 12

Strophocardia, 5

Venericardia, 12

Milneria, 17,28

kelseyi, 28

minima, 17, 28, 39

minima, Ceropsis, 28

Milneria, 17, 28; pl. 9

minuscula, Glans, 15

Miodon prolongatus, 16

Miodontiscus, prolongatus, 12, 16; pl. 5

monilicosta, Cardita, 13

monilicosta, Cardita

Montacutidae, 1,9

montereyana, Cyclocardia (Cyclocardia), 12, 13;

Venericardia, 13

Moore, R.C., cited,

Morris, R.H., cited, 4,

Muir Sandstone, 24

mulleri, Venericardia, 19

(Pacificor), 17, 18, 19; pl. 1

Mysella, 5,9
tumica, 9

(Rochefortia) tumida, 5, 9; pl. 7

Mytilus, 5,6

\section{$\mathbf{N}$}

Neaeromya, 5, 9

(Orbitella) compressa, 5,$10 ; \mathrm{pl} .4$

nelsoni, Venericardia (Pacificor), 17, 18, 19; pl. 1

nuca, Aligena aequata, 8

oblongus, Pristes, 9

Thecodonta (Pristes), 5, 9; pl. 4

occidentalis, Cardita,

Cyclocardia, 13

(Cyclocardia), 12, 13; pl. 9

Olsson, A A cited, 1

quoted, 11,12
Orbitella, 10

"Orbitella" compresssa, 10

(Orbitella), Neaeromya compressa, 5, 10; pl. 4

oregonensis, Venericardia (Pacificor), 21; pl. 3

\section{P}

(Pacificor), 1, 16, 18

Venericardia

aragonia

aragonia, 18, 24

diabloensis, 17, 18, 20; pl. 5 joaquinensis, 17, 18, 23; pls. 6, 8, 9

argentea, 27,3

calafia, 2

calafia, 17, 18, 21; pl. 3

gabbi, 17,22; pl. 4

lutmani, $17,18,20$; pls. $2,4,5$

susanaensis, 17, 19; pl.

clarki

clarki, 17, 18, 22; pl. 5

popenoei, 17, 18, 24; pl. 9

crescentensis, 18

diabloensis, 20, pl. 2

durhami, 20, pl. 2

gabbi, 22

hertleini, 21, pl. 3

hornii, 17, 18, 22, 23; pl. 5

carlosensis, pl. 2

lutmani, 20

susanaensis, 19

lisa, 22, 23, 24

lutmani, 20

mulleri, 17, 18, 19; pl. 1

nelsoni, 17, 18, 19; pl. 1

oregonensis, $21, \mathrm{pl} .3$

popenoei, 25

smileyi, pls. 6, 9

susanaensis, 19

taliaferroi, 1, 17,18; pl. 5

transversaria, 19

vallecitosensis, 25

vokesi, pls. 8,9

weaveri, 22 , pl. 5

Palmer, K.V.W., cited, 9

Pancho Rico Formation, 13

Pelecyora aequilateralis, 26

peninsulare, Basteotia, 11

phylogeny, Glyptoactis, 18

Venericardia, 18

Pico Formation, 14

planicosta, Cardita, 22

Venericardia,

hornii, 22

venturensis, 19, 25

popenoei, Venericardia, 25

(Leuroactis), 24

(Pacificor) clarki, 17, 18, 24; pl. 9 popenoei, 25

Pristes, oblongus, 9

(Pristes), Thecodonta oblongus, 5, 9; pl. 4

Procedure, 1

prolongatus, Miodon, 16

Miodontiscus, 12, 16; pl. 5

Pseudopythina compressa, 10

(Pseudopythina), Erycina compressa, 10

Purpose and scope, 1

purpurata, Lasaea, 6

References, 30

Rio Dell Formation, 10, 14, 15

(Rochefortia), Mysella

tumida, 5, 9; $\mathrm{pl}, 9$

Rose Canyon Shale, 7, 21, 22, 27

Roseburg Formation, 20

Roth, Barry, quoted, 10

rotunda, Kellia, 7

Round Mountain Silt, 8

rubra, Lasaea 6

subviridis, 6

rufescens, Haliotis, 28

Sacate Formation, 25

Sakamoto, Kenji, cited, 4

San Diego Formation, 7, 8, 9, 13, 14, 16, 28

San Francisquito Formation, 17

San Pedro Formation, 7, 14, 15, 16

Sand, 13

sandiegoensis, Cardita, 26

Glyptoactis, 27 
(Claibornicardia), 17, 18, 26; pls. 1, 7 Venericardia, 26

Santa Barbara Formation, 13, 15, 16

Santa Susana Formation, 19, 25 ,

Shale, 20, 24

Saugus Formation, 13

Saul, LouElla, quoted, 25

scalaria, Lasaea , 6

schenck, Venericardia (Leuroactis), 23; pl. 6

Semeloidea, 8

simiana, Venericardia (Venericor), 25; pl. 8

Sisquoc Formation, 13

smileyi, Megacardita (Venericor) aragonia, 23 Venericardia (Leuroactis), 23 (Pacificor), pls. 6, 9

Smith, A.G., cited, 4, 6

Sportellidae, 1,10

Squires, R.L., quoted, 28

Stanley, S.M., cited, 4

Stenoplax conspicua, 9

Stewart, R.B., cited, 27 quoted, 16

Strong, A.M., cited, 12

Strophocardia megastropha, 5, 11

(Strophocardia), Cardita

megastropha, 12; pl. 7

suborbicularis, Chironia laperousii, 7 Kellia, 7

subquadrata, Glans, 15

(Glans), 12, 15; pl. 5

Lazaria, 15

subviridis, Lasaea, 5, 6; pl. 1

Lasaea rubra, 6

superioris, Cardita, 11

(Cardita) 5,$11 ; \mathrm{pl} .4$

susanaensis, Venericardia (Pacificor), 19 calafia, 17, 18, 19; pl. 1

hornii, 19

swiftiana, Corbula (Cuneocorbula) harrisi, 6

Systematics, Pelecypods, 5

\section{$\mathrm{T}$}

taliaferroi, Venericardia (Pacificor), 1, 17, 18; pl. 5 Tejon Formation, 6, 22, 23, 27, 28

Tellimya tumida, 9

Temblornia, 8

(Temblornia), Bornia

frankiana, 5,8 ; pl. 3

triangulata, 5,$8 ; \mathrm{pl} .3$

Thecodonta (Pristes) oblongus, 5,$9 ; \mathrm{pl} .4$

Thompson, T.E., cited, 4

Timms Point Silt Member, 14, 16

Towsley Formation, 13

transversaria, Venericardia (Pacificor), 19

triangulata, Bornia (Temblornia), 5, 8; pl. 3

Donax, 8

tumida, Mysella, 9

(Rochefortia), 5, 9; pl. 7

Tellimya, 9

turrita, Loxotrema, 26

U

Umpqua Group, 20, 21

uvasana, Corbula, 6
Kellia, $5,6,7 ; \mathrm{pl} .3$

\section{V}

vallecitosensis, Glyptoactis (Venericor), 18 Megacardita (Venericor), 25

Venericardic

(Pacificor), 25

(Venericor), 17, 25; pl. 2

Venericardia, 4, 16, 17, 18

acuticostata, 28

argentea, 19

barbarensis, 13, 15

borealis, 13

clarki, 22, 23

(Cyclocardia)

alaskana, 14, 39

californica, 13

domenginica, 27, 28

gabbi, 22, 23

(Glyptoactis)

domenginica, 27

keenae, 27

marksi, 27

mcmastersi, 26

(Glyptoactis?)

domenginica, 27
hornii, $20,21,22,23$

calafia, 21,22

clarki, 22, 23

lutmani, 20, 21

ionensis, 23, 25

joaquinensis, 24, 25

joaquinensis,

alisoensis, 23, 36

joaquinensis, 23

popenoei, 24

schencki, 23; pl. 6

smileyi, 23

lutmani, 20, 22

marksi, 27

megastropha, 12

montereyana,

mulleri, 19

(Pacificor)

aragonia

aragonia, 18, 24

diabloensis, 17, 18,20; pl. 5

joaquinensis, 17, 18, 23; pls. 6, 8,9

argentea, $27 ; \mathrm{p1} .8$

calafia 21

calafia, 17, 18, 21; pl. 3

gabbi, $17,18,22 ;$ pl. 4

lutmani, 17, 18, 20, pls. $2,4,5$

susanaensis, 17, 18, 19; pl. 1

clarki

clarki, 17, 18, 22; pl. 5

popenoei, 17, 18, 24; pl. 9

crescentensis, 18

diabloensis, 20; $\mathrm{pl}$.

diabloensis, $20 ; \mathrm{pl}$.

gabbi, 22

gabbi, 22 , 2 ; pl. 3

hornii, 17, 18, 22, 23; pl. 5

carlosensis, pl. 2

lutmani, 20

susanaensis, 19

lisa, 22, 23, 24

lutmani, 20

mulleri, 17, 18, 19; pl. 1

nelsoni, 17, 18; $\mathrm{pl}$. 1

oregonensis, 21 , p1. 1 popenoei, 25

smileyi, pls. 6, 9

taliaferroi, $1,17,18$; pl. 5

transversaria, 19

vallecitosensis, 25

vokesi, pls. 8, 9

weaveri; $22, \mathrm{pl} .5$

planicosta, 22

hornii, 22

venturensis, 19, 25

popenoei, 25

sandiegoensis, 26

(Venericor)

carlosensis, 25

hornii, 23

simiana, 25, 38

vallecitosensis, 17,$25 ; \mathrm{pl} .2$

venturensis, 17, 25; pl. 8

ventricosa, 13,14

venturensis, 17,25

weaveri, 23

yatesi, 16

nelsoni, 19

Venericardinae, 16

Venericor, 17, 18, 25

(Venericor)

Glyptoactis

vallecitosensis, 18

venturensis, 18

Megacardita

aragonia smileyi, 23

hornii

carlosensis, 25

joaquinensis, 23

vallecitosensis, 25

Venericardia.

carlosensis, 25

hornii, 23

simiana, 25, 38

vallecitosensis, 17,$25 ; \mathrm{pl} .2$

venturensis, 17,25 ; pI. 8

veneriformis, Cardita, 16

"Cardita," 16

Glans (Centrocardita), 12, 16; pl. 7

ventricosa, Cardita, 14

Cyclocardia, 14

(Cyclocardia), 12, 14; pl. 9

Venericardia, 13,14

venturensis, Glyptoactis (Venericor), 18

Venericardia, 17, 25

planicosta, 19, 25

(Venericor), 17,25; pl. 8

Verastegui, Pedro, cited, 27

quoted, 27

Vokes, H.E., quoted, 26

vokesi, Venericardia (Leuroactis), 23

(Pacificor); pls. 8, 9

w

Waring, C.A., cited, 11

weaveri, Venericardia, 23

(Pacificor), 22; pl. 5

Woodring, W.P., cited, 13

quoted, 15

\section{$\mathbf{Y}$}

yatesi, Venericardia, 16

Yonge, C.M., cited, 4, 7, 15 


\section{.}




\section{PLATES 1-9}

[Contact photographs of the plates in this report are available, at cost, from the U.S. Geological Survey Library, Federal Center, Denver, Colorado 80225] 


\section{PLATE 1}

Figures 1, 5, 11. Venericardia (Pacificor) mulleri Verastegui (p. E19).

Holotype CAS/SU 7994. Base of Lodo Formation, California. Paleocene.

2, 4. Lasaea subviridis Dall (p. E6).

CAS 043249 (×7.3). San Diego, California. Holocene.

3, 20. Venericardia (Pacificor) nelsoni Verastegui (p. E19).

Holotype UCMP 32804. Santa Susana Formation of Zinsmeister (1983), California. Paleocene.

6, 8-10, 12, 13. Aligena (Aligena) diegoana Hertlein and Grant (p. E7).

6, 8. Paratype LACMP 4548 ( $\times 4.5$ ). San Diego Formation, California. Pliocene.

9, 10. Holotype LACMP 4547 (×3.0). San Diego Formation, California. Pliocene.

12, 13. Paratype LACMP 4551 (×4.5). San Diego Formation, California. Pliocene.

7. Kellia catacta Anderson and GD. Hanna (p. E6).

Holotype CAS 275 ( $\times 3.0)$. Tejon Formation, California. Eocene.

14, 16-18. Venericardia (Pacificor) calafia susanaensis Verastegui (p. E19).

Holotype CAS/SU 8004. Santa Susana Shale of Verastegui (1953), California. Eocene.

15, 19, 21. Glyptoactis (Claibornicardia) sandiegoensis (Hanna) (p. E26).

15, 21. Syntype UCMP 30982 (latex). Rose Canyon Shale of Hanna (1927), California. Eocene.

19. Syntype UCMP 30980, latex. impression. Rose Canyon Shale, of Hanna (1927), California. Eocene. 
U.S. GEOLOGICAL SURVEY

PROFESSIONAL PAPER 1228-E PLATE 1

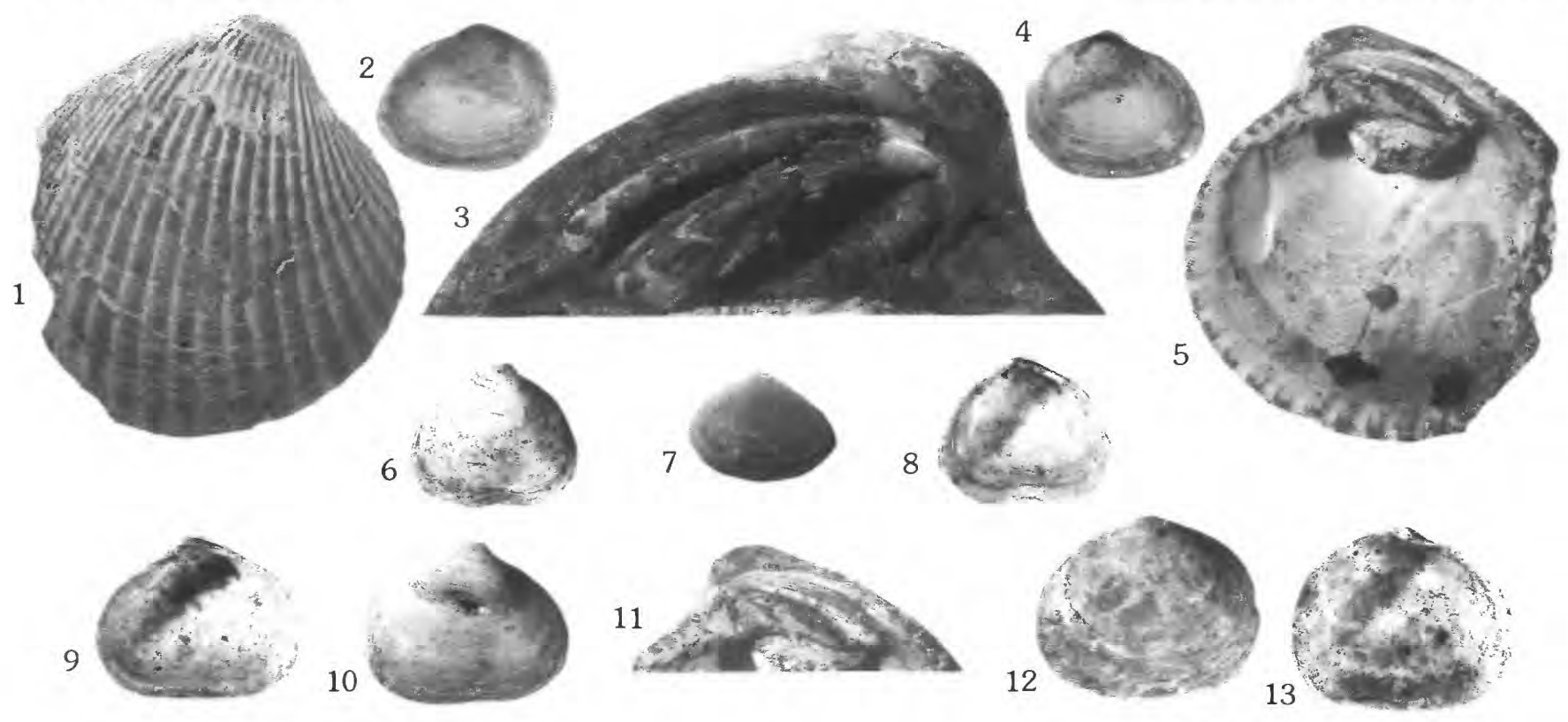

14
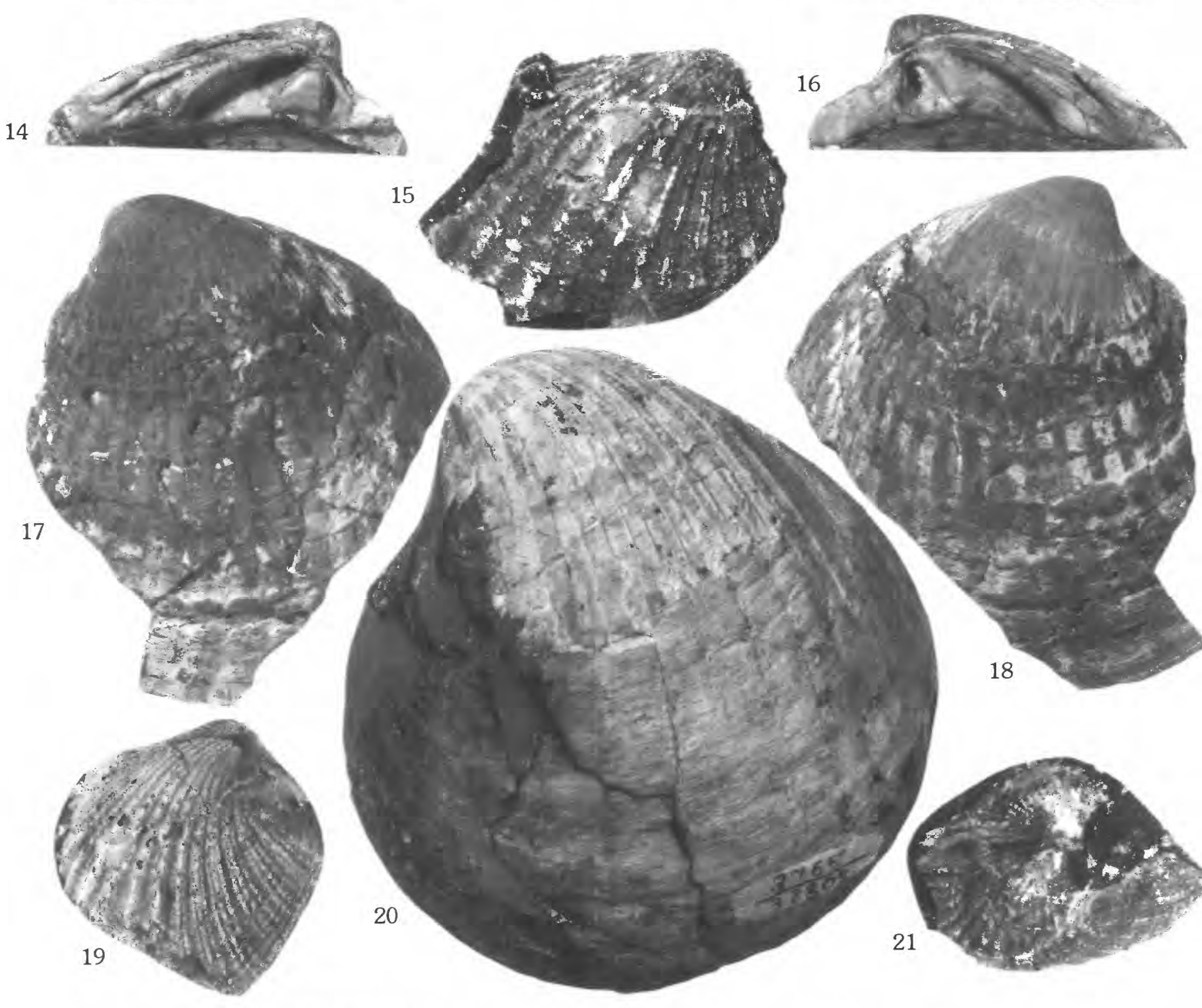

15
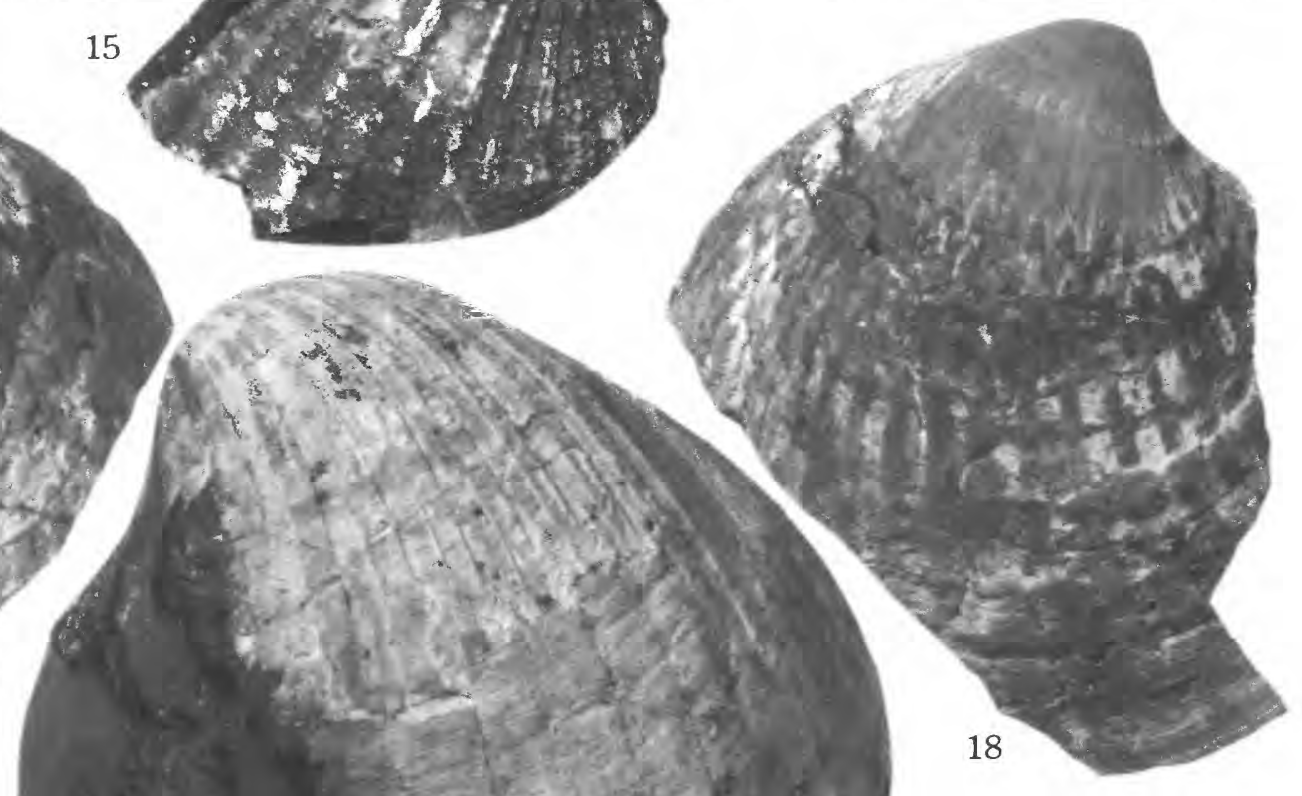

VENERICARDIA, LASAEA, ALIGENA, KELLIA, GLYPTOACTIS 


\section{PLATE 2}

Figures 1, 2. Venericardia (Pacificor) calafia lutmani Turner (p. E20).

Holotype of Venericardia (Pacificor) durhami Verastegui CAS/SU 8005. Juncal Formation, California. Eocene.

3-5, 7. Venericardia (Venericor) vallecitosensis (Vokes) (p. E25).

3, 4. Holotype of Venericardia (Pacificor) hornii carlosensis Verastegui, UCMP 15619. Domengine Formation, California. Eocene.

5. Holotype UCMP 15614. Domengine Formation, California. Eocene.

7. Paratype UCMP 15615. Domengine Formation, California. Eocene. 8, 9. Venericardia (Pacificor) aragonia diabloensis Verastegui (p. E20).

8. Paratype UCMP 32799. Meganos Formation, California. Paleocene and Eocene.

9. Holotype CAS/SU 411. Meganos Formation, California. Paleocene and Eocene. 


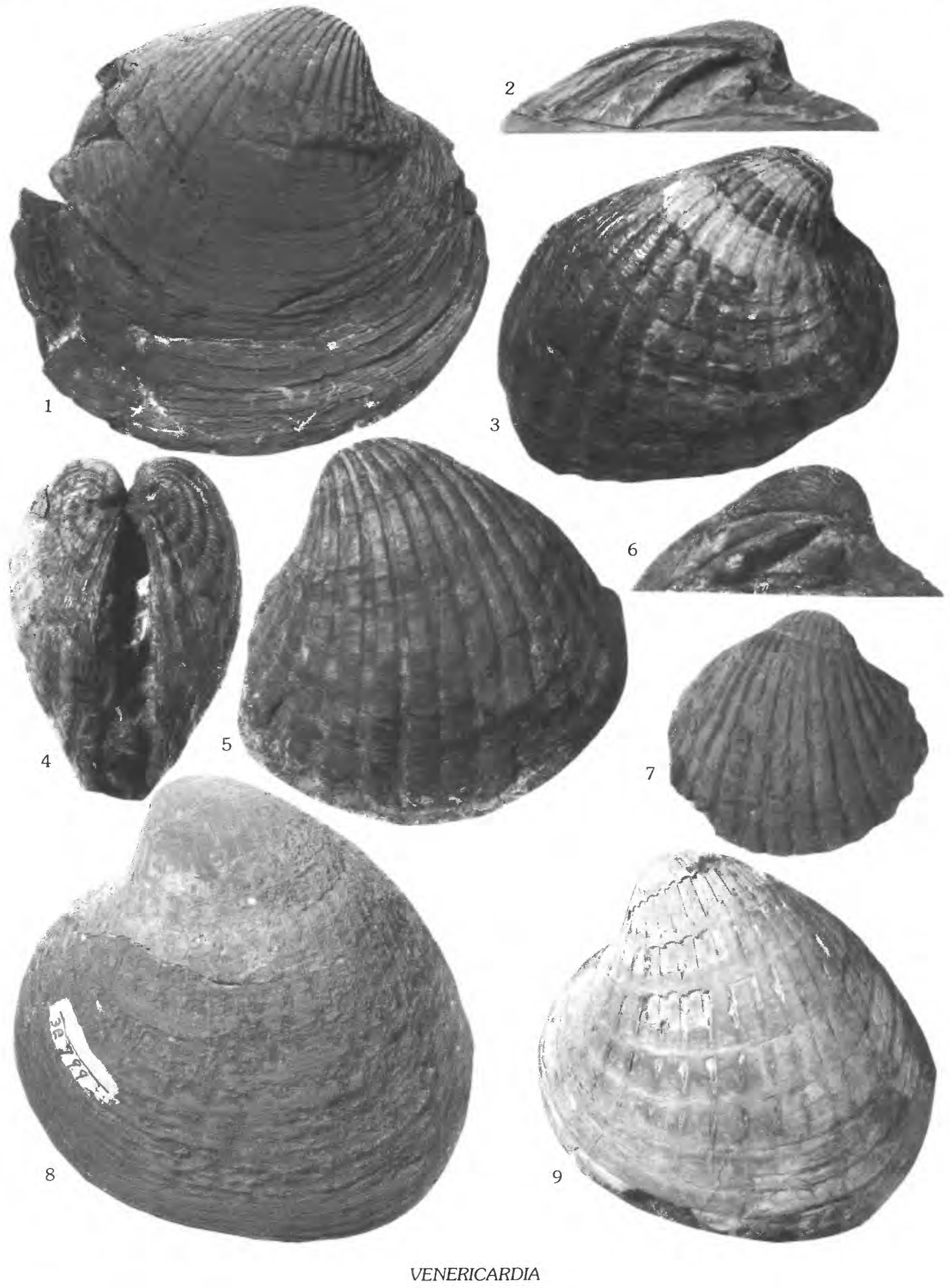




\section{PLATE 3}

Figures 1-7, 11, 16, 19. Venericardia (Pacificor) calafia calafia Stewart (p. E21).

1, 2, 5, 6. Hypotype CAS 8017 (×0.8) (Verastegui, 1953, pl. 16, figs. 2, 3;pl. 17, figs. 1, la, 2, 2a). Llajas Formation, California. Eocene.

3, 4. Holotype UCMP 31450. Llajas Formation, California. Eocene.

7, 16. Holotype of Venericardia (Pacificor) oregonensis Verastegui, CAS/SU 8009. Umpqua Formation, Oregon. Eocene.

11, 19. Holotype of Venericardia (Pacificor) hertleini Verastegui, UCMP 30415. Rose Canyon Shale of Hanna (1927), California. Eocene.

8. Kellia lajollaensis Hanna (p. E6).

Holotype UCMP 31036. Rose Canyon Shale of Hanna (1927), California. Eocene.

9, 12. Kellia uvasana (Dickerson) (p. E6)

9. Holotype CAS 276. Tejon Formation, California. Eocene.

12. Hypotype CAS 894 (Anderson and GD. Hanna, 1925, pl. 9, fig. 11). Tejon Formation, California. Eocene.

10, 15. Kellia laperousii (Deshayes) (p. E7).

Hypotype LACMP 4623 (Hertlein and Grant, 1972, pl. 44, figs. ll, 19) (x7.0). San Diego Formation, California. Pliocene.

13, 14. Bornia (Temblornia) frankiana Hertlein and Grant (p. E8).

Holotype LACMP 4624 ( $\times 3.0$ ). San Diego Formation, California. Pliocene.

17, 18. Bornia (Temblorniana) triangulata (Anderson and Martin) (p. E8).

Holotype CAS $130(\times 3.0)$. Round Mountain Silt, California. Miocene. 


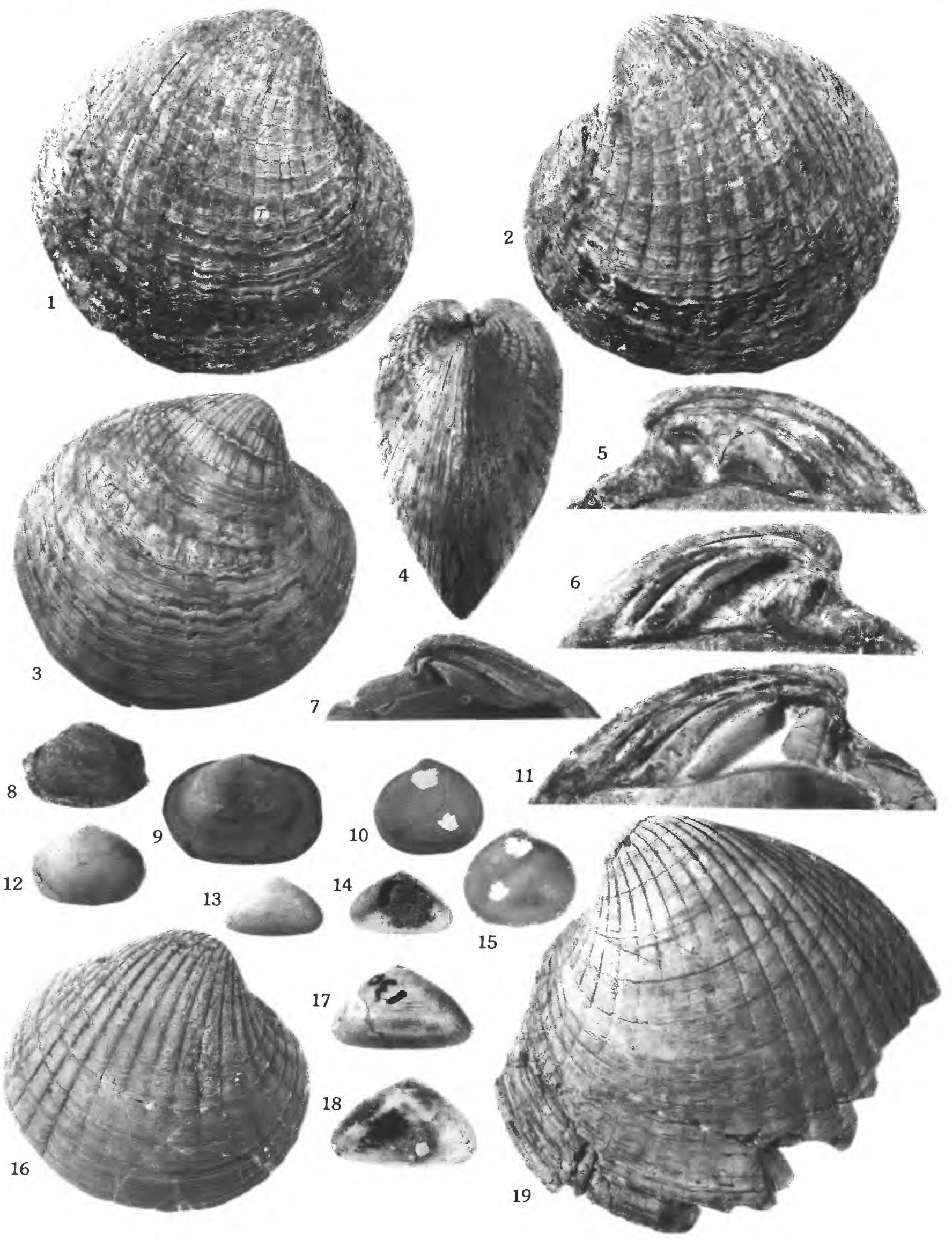

VENERICARDIA, KELLIA, BORNIA 


\section{PLATE 4}

Figures 1, 12, 13. Venericardia (Pacificor) calafia lutmani Turner (p. E20).

1, 12. Holotype UCMP 33133. Umpqua Formation, Oregon. Eocene. 13. Hypotype UCMP 33009.

2, 6, 8, 10. Venericardia (Pacificor) calafia gabbi Verastegui (p. E22).

2 , 10. Holotype CAS $686(\times 0.8)$. Tejon Formation, California. Eocene.

6, 8. Hypotype CAS 685 (×0.8) (M.A. Hanna, 1925, pl. 39, fig. 1). Tejon Formation, California. Eocene.

3, 4. Thecodonta (Pristes) oblongus (Carpenter) (p. E9).

Hypotype LACMP 4630 (×7.0) (Hertlein and Grant, 1972, pl. 44, figs. 9, 13). San Diego Formation, California. Pliocene.

5, 7. Neaeromya (Orbitella) compressa (Dall) (p. E10).

Hypotype of Roth (1979). Lower part of the Rio Dell Formation, California. Pliocene.

9, 11. Cardita (Cardita) superioris Waring (p. E11).

Holotype CAS/SU 143. Llajas Formation, California. Eocene. 

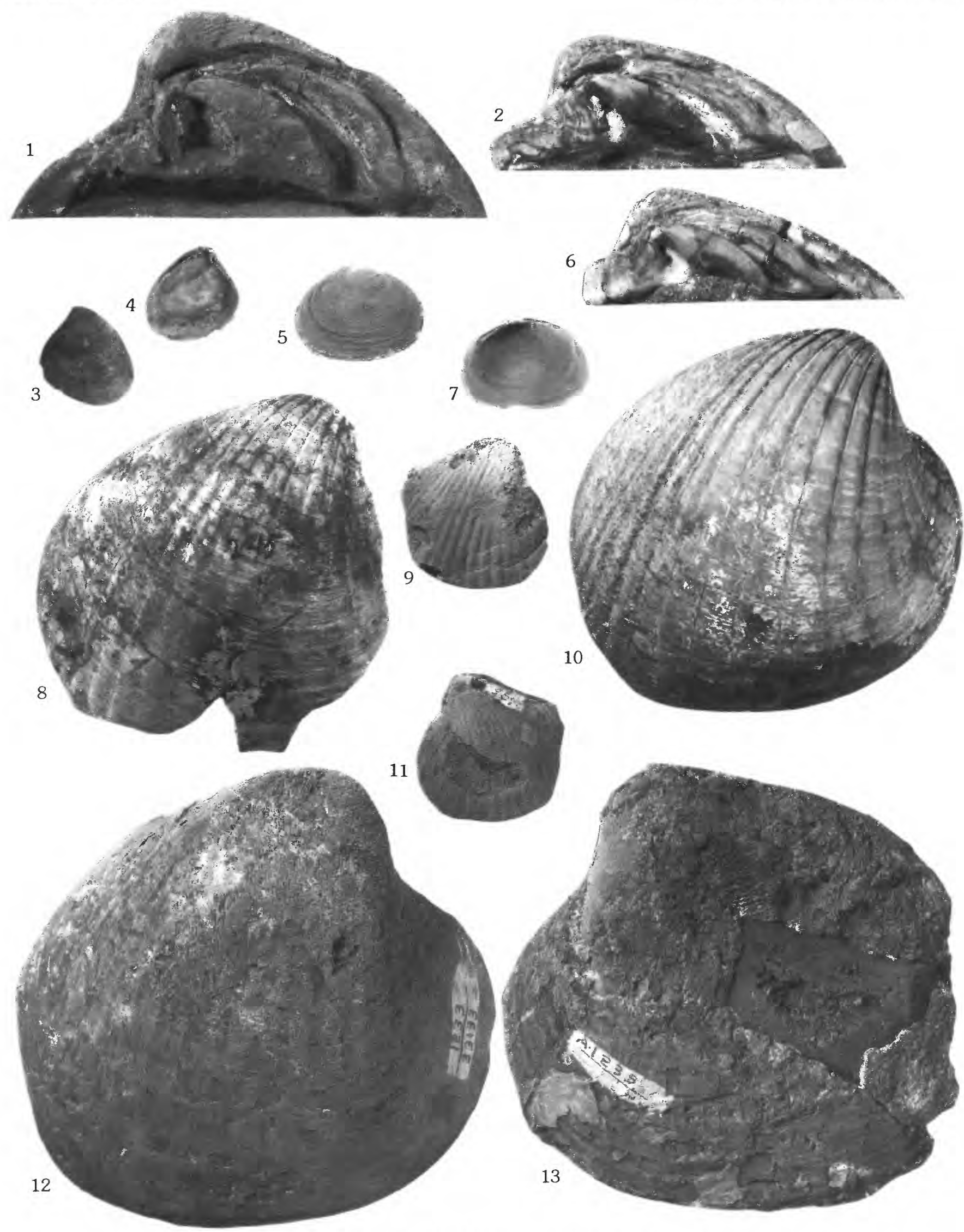

VENERICARDIA, THECODONTA, NEAEROMYA, CARDITA 


\section{PLATE 5}

Figures 1. Venericardia (Pacificor) calafia lutmani Turner (p. E20).

Hypotype UCMP 33009. Juncal Formation, California. Eocene.

2, 5. Venericardia (Pacificor) aragonia diabloensis Verastegui (p. E20).

2. Paratype UCMP 32799. Meganos Formation, California. Paleocene and Eocene.

5. Holotype CAS/SU 411. Meganos Formation, California. Paleocene and Eocene.

3, 7, 8. Venericardia (Pacificor) taliaferroi Verastegui (p. E17).

3, 7. Hypotype CAS 7997.

8. Holotype CAS/SU $7996(\times 2.0)$. Dip Creek Formation of Verastegui (1953), California. Cretaceous and Paleocene.

4, 6. Venericardia (Pacificor) clarki clarki Weaver and Palmer (p. E22).

Holotype of Venericardia (Pacificor) weaveri Verastegui CAS/SU 8024. Cowlitz Formation, Washington. Eocene.

9, 15. Cyclocardia (Cyclocardia) barbarensis (Stearns) (p. E15).

Lectotype USNM 104045 ( $\times 2.0$ ). Santa Barbara, California. Holocene.

10, 11. Glans (Glans) subquadrata (Carpenter) (p. E15).

Hypotype LACMP 4539 ( $\times 3.5$ ). San Diego Formation, California. Pliocene.

12-14, 16. Miodontiscus prolongatus (Carpenter) (p. E16).

12, 16. Hypotype LACMP 4544 ( $\times 3.0$ ). San Diego Formation, California. Pliocene.

13, 14. Hypotype LACMP 4541 ( $\times 3.0$ ). San Diego Formation, California. Pliocene.

17, 18. Venericardia (Pacificor) hornii (Gabb) (p. E23).

Lectotype ANSP 4558. Tejon Formation, California. Eocene. 


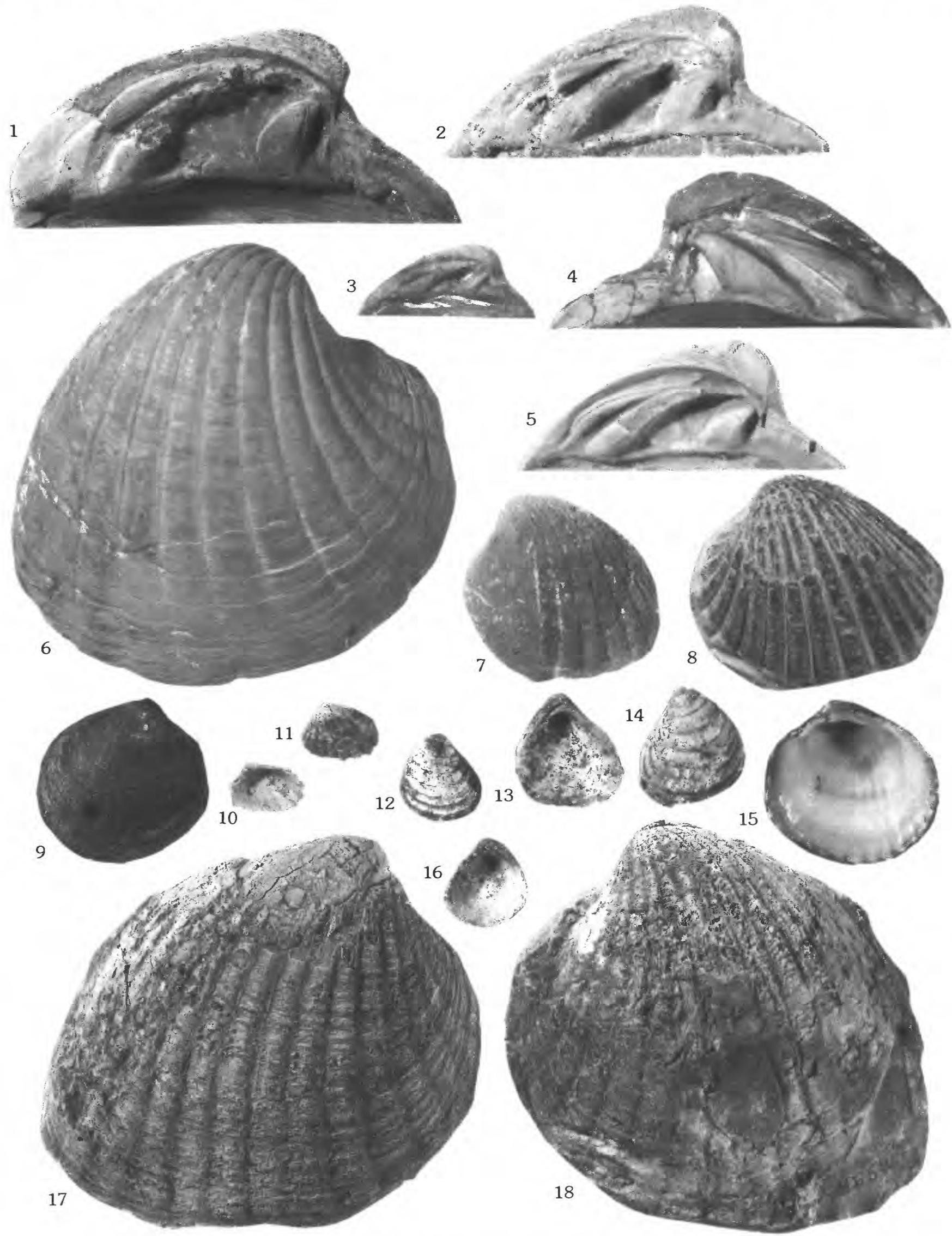


PLATE 6

FiguRES 1-10. Venericardia (Pacificor) aragonia joaquinensis (Vokes) (p. E23).

1,9. Hypotype UCMP 15615 (x0.8). Avenal Sandstone, California. Eocene.

2, 8. Holotype of Venericardia (Leuroactis) alisoensis Verastegui UCMP 30176. Llajas Formation, California. Eocene.

3,10 . Paratype UCMP $15617(\times 0.8)$. Avenal Sandstone, California. Eocene.

4, 6. Holotype of Venericardia (Leuroactis) schencki Verastegui, CAS/SU 8003. Santa Susana Formation of Verastegui (1953), California. Eocene.

5. Holotype of Venericardia (Pacificor) smileyi (Vokes) UCMP 15626. Domengine Formation, California. Eocene.

7. Paratype of Venericardia (Pacificor) smileyi (Vokes) UCMP 15627. Domengine Formation, California. Eocene. 

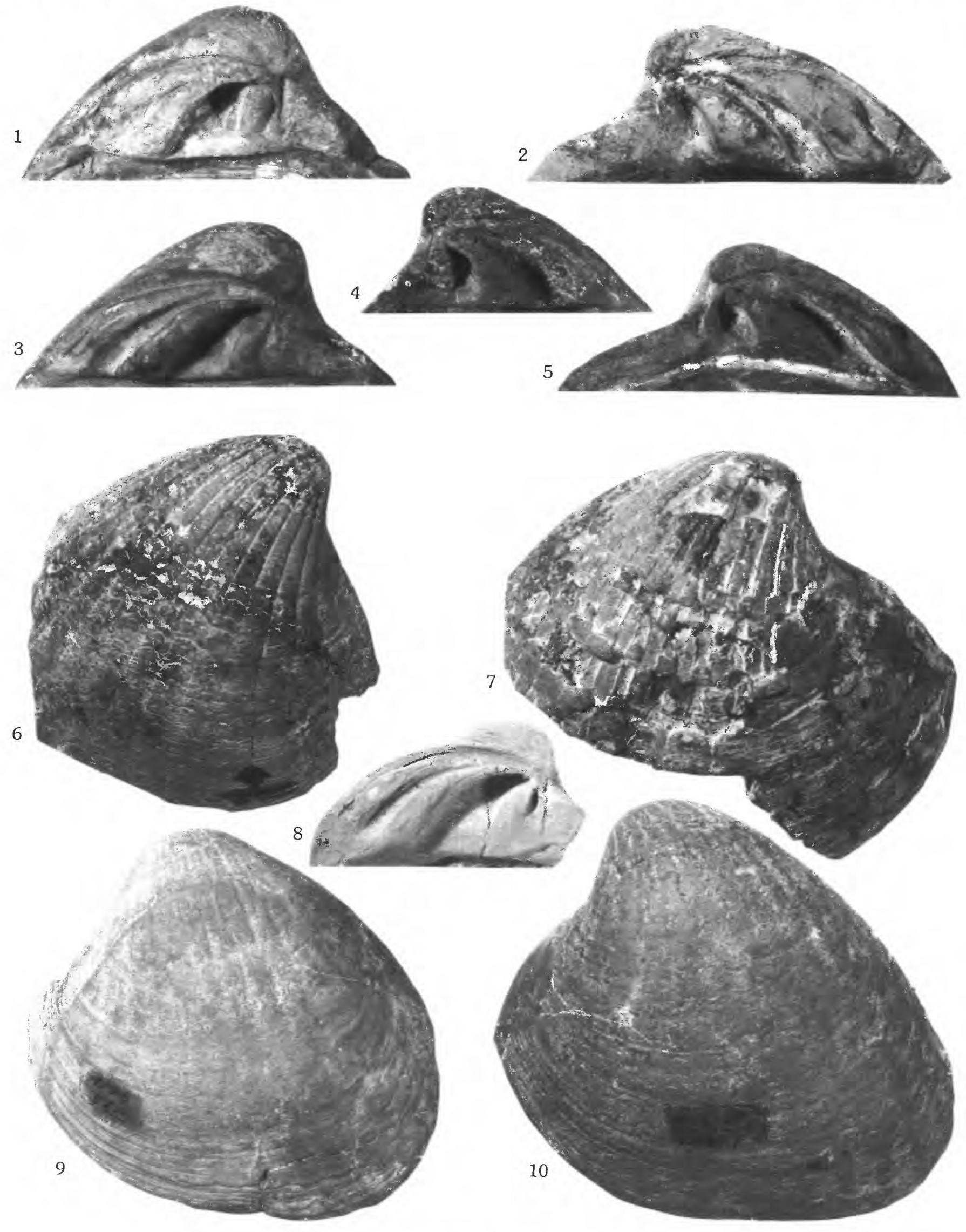

VENERICARDIA 


\section{PLATE 7}

Figures 1, 2, 11, 14. Cardita (Strophocardia) megastropha (Gray) (p. E12).

1, 14. Hypotype (Durham, 1950, pl. 16, figs. 6, 11). UCMP 30517. Unnamed Pleistocene strata, Baja California Sur.

2, 11. Hypotype UCMP 30518 (Durham, 1950). Unnamed Pleistocene strata, Baja California Sur.

3, 4. Cyclocardia (Cyclocardia) californica (Dall) (p. E13).

Holotype USNM 164558 ( $\times 1.5$ ). Santa Barbara Formation, California. Pliocene and Pleistocene.

5, 6. Mysella (Rochefortia) tumida (Carpenter) (p. E9).

Hypotype LACMP 4625. San Diego, California. Pliocene. (Photocopy of Hertlein and Grant, 1972, pl. 44, figs. 2, 4.)

7-9. Glans (Centrocardita) veneriformis (Gabb) (p. E16).

7, 8. Holotype ANSP $4381(\times 2.0)$. Martinez(?) Formation, California. Paleocene(?).

9. Paratype ANSP 4381a ( $\times 2.0)$. Martinez(?) Formation, California. Paleocene.

$10,12,13,16,18,20$. Glyptoactis (Claibornicardia) domenginica (Vokes) (p. E27).

10, 18. Paratype UCMP $15613(\times 2.0)$. Domengine Formation, California. Eocene

12, 16, 20. Paratype UCMP $15612(\times 2.0)$. Domengine Formation, California. Eocene.

13. Holotype UCMP 15611 ( $\times 1.5)$. Domengine Formation, California. Eocene.

15, 22. Glyptoactis (Claibornicardia) sandiegoensis (M.A. Hanna) (p. E26).

Holotype of Glyptoactis (Claibornicardia) mcmastersi Verastegui

CAS 8011 (×2.0). La Jolla Group, California. Eocene.

17, 19. Glyptoactis (Claibornicardia) marksi Verastegui (p. E27).

Holotype CAS/SU 8021. Live Oak Member of Verastegui (1953),

Tejon Formation, California. Eocene.

21. Cyclocardia (Cyclocardia) montereyana (Arnold) (p. E13).

Holotype USNM 165464. Monterey Shale, California. Miocene.

23, 24. Cyclocardia (Cyclocardia) crebricostata (Krause) (p. E14).

23. Lectotype Museum der Humboldt-Universität, Berlin 37934 (Coan, 1977) (×2.0). St. Paul Island, Bering Sea, Alaska. Holocene.

24. Lectoparatype Museum der Humboldt-Universität, Berlin 379311.(Coan, 1977) (×2.0). St. Paul Island, Bering Sea, Alaska. Holocene. 

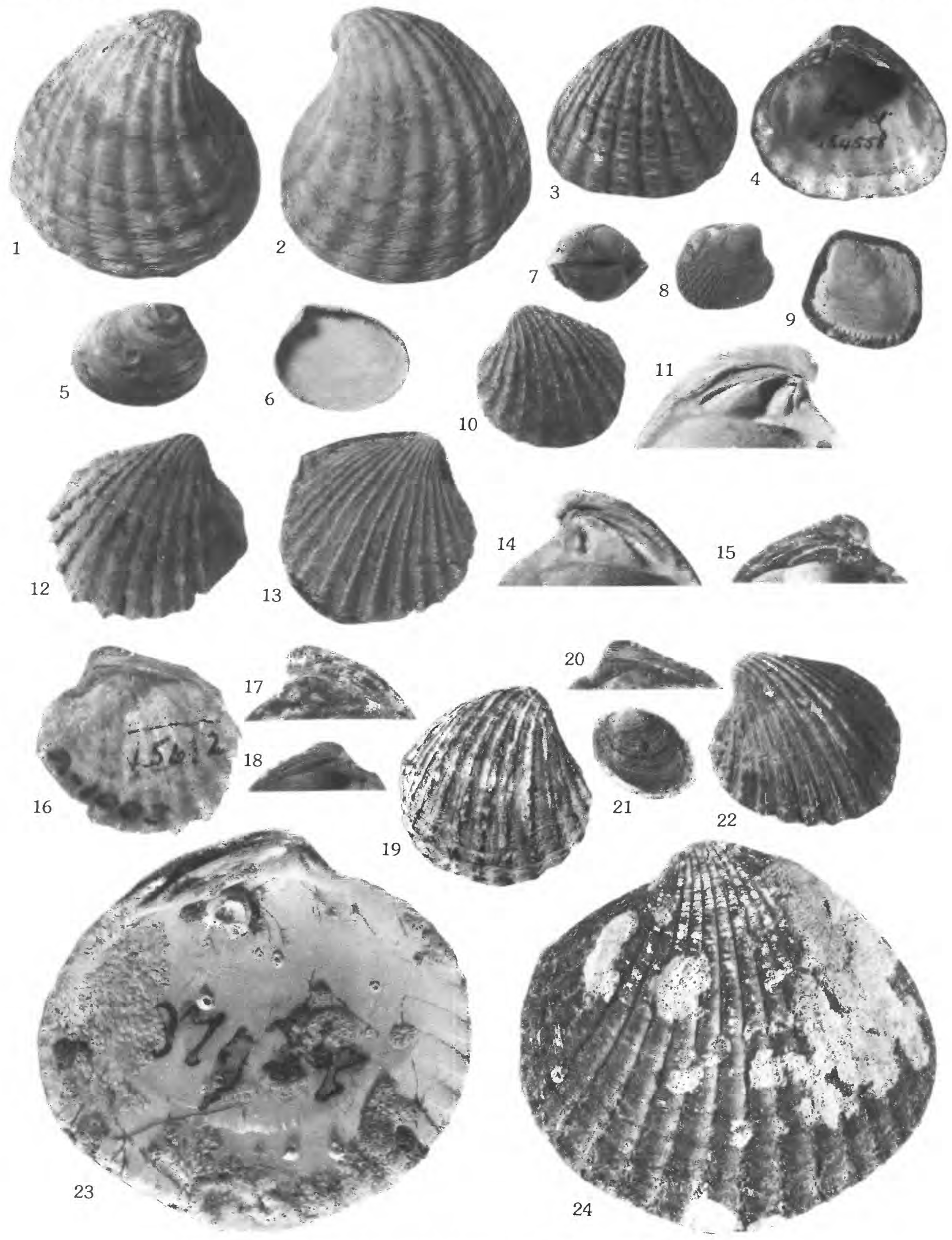

CARDITA, CYCLOCARDIA, MYSELLA, GLANS, GLYPTOACTIS 


\section{PLATE 8}

Figures $1,2,4,5,7,9,11,14$. Venericardia (Venericor) venturensis Waring (p. E25).

1, 9. Hypotype CAS 319. Santa Susana Formation, California. Paleocene.

2, 11. Paratype of Venericardia (Venericor) simiana Verastegui CAS 8002. Santa Susana Formation, California. Paleocene.

4. Hypotype CAS 318. Santa Susana Formation, of Zinsmeister (1983), California. Paleocene.

5, 14. Holotype of Venericardia (Venericor) simiana Verastegui CAS/SU 8001. Santa Susana Formation, California. Paleocene.

7. Holotype CAS 159. Santa Susana Formation, California. Paleocene.

3. Venericardia (Pacificor) aragonia joaquinensis (Vokes) (p. E23).

Paratype of Venericardia (Pacificor) vokesi Verastegui

CAS/SU 8016. Avenal Sandstone, California. Eocene.

$6,8,10,12,13,15$. Glyptoactis (Claibornicardia) keenae (Verastegui) (p. E27).

6,15 . Holotype of Venericardia (Pacificor) argentea Verastegui CAS/SU 7995. Base of Lodo Formation, California. Paleocene.

8, 13. Hypotype UCMP $33001(\times 1.5)$.

10, 12. Holotype CAS/SU 7992. Base of Lodo Formation, California. Paleocene. 


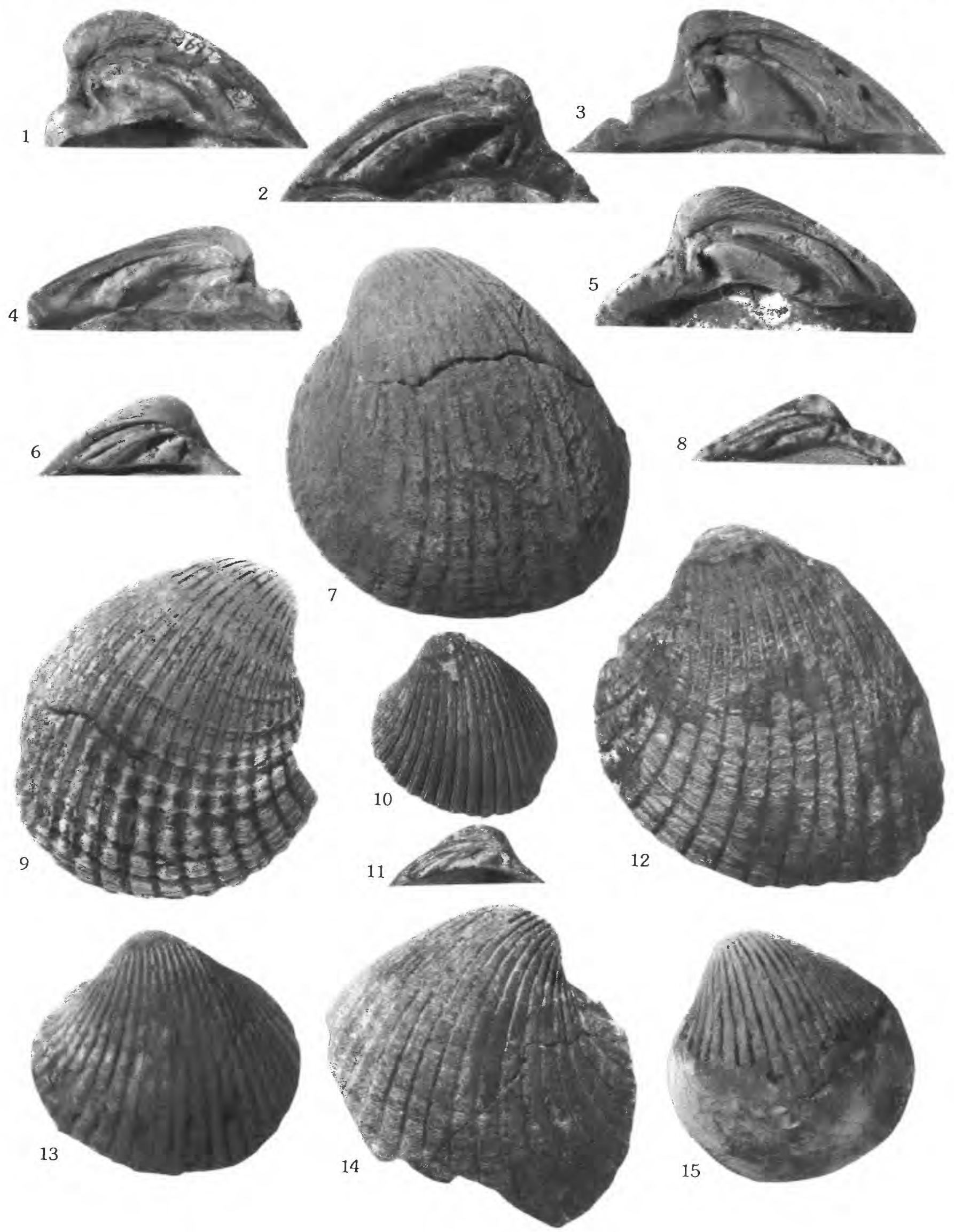

VENERICARDIA, GLYPTOACTIS 


\section{PLATE 9}

Figures 1, 2. Cyclocardia (Cyclocardia) crebricostata (Krause) (p. E14).

Holotype of Venericardia (Cyclocardia) alaskana Dall USNM 109271 (x1.5). Bering Sea, Alaska. Holocene.

3-6. Cyclocardia (Cyclocardia) occidentalis (Conrad) (p. E13).

3, 5. Hypotypes UCLA 48619 (×1.5) (Hertlein and Grant, 1972). San Diego Formation, California. Pliocene.

4, 6. Hypotypes UCLA 48616 (×1.5). San Diego Formation, California. Pliocene.

7, 15. Venericardia (Pacificor) clarki popenoei Verastegui (p. E24).

Holotype UCMP 15689. "Coldwater" Formation, of Verastegui (1953),

California. Eocene. (Photocopy of Verastegui, 1953, pl. 21, figs. 1, 2.)

8, 14. Basterotia (Basterotella) hertleini Durham (p. E10).

Holotype UCMP $32274(\times 3.0)$. Comondú Formation, Baja California Sur. Pliocene.

9, 10. Cyclocardia (Cyclocardia) ventricosa (Gould) (p. E14).

Hypotype LACMP 4537 ( $\times 1.5)$ (Hertlein and Grant, 1972, pl. 43, figs. 3, 8). San Diego Formation, California. Pliocene.

11, 13. Cardita (Byssomera) affinis Sowerby (p. E11).

Hypotype UCMP 30626. Unnamed Pleistocene strata on Isla Carmen, Baja California Sur.

12. Cyclocardia (Cyclocardia) kirkerensis (Clark) (p. E12).

Holotype UCMP $11165(\times 2.0)$. Kirker Tuff, California. Oligocene.

16, 18. Milneria minima (Dall) (p. E28).

Hypotype LACMP 4546 ( $\times 7.0$ ). (Hertlein and Grant, 1972, pl. 43, figs. 1, 2, 14) San Diego Formation, California. Pliocene.

17, 19. Venericardia (Pacificor) aragonia joaquinensis (Vokes) (p. E23).

17. Holotype of Venericardia (Pacificor) smileyi (Vokes) UCMP 15626. Domengine Formation, California. Eocene.

19. Paratype of Venericardia (Pacificor) vokesi Verastegui CAS/SU 8016. Avenal Sandstone, California. Eocene. 


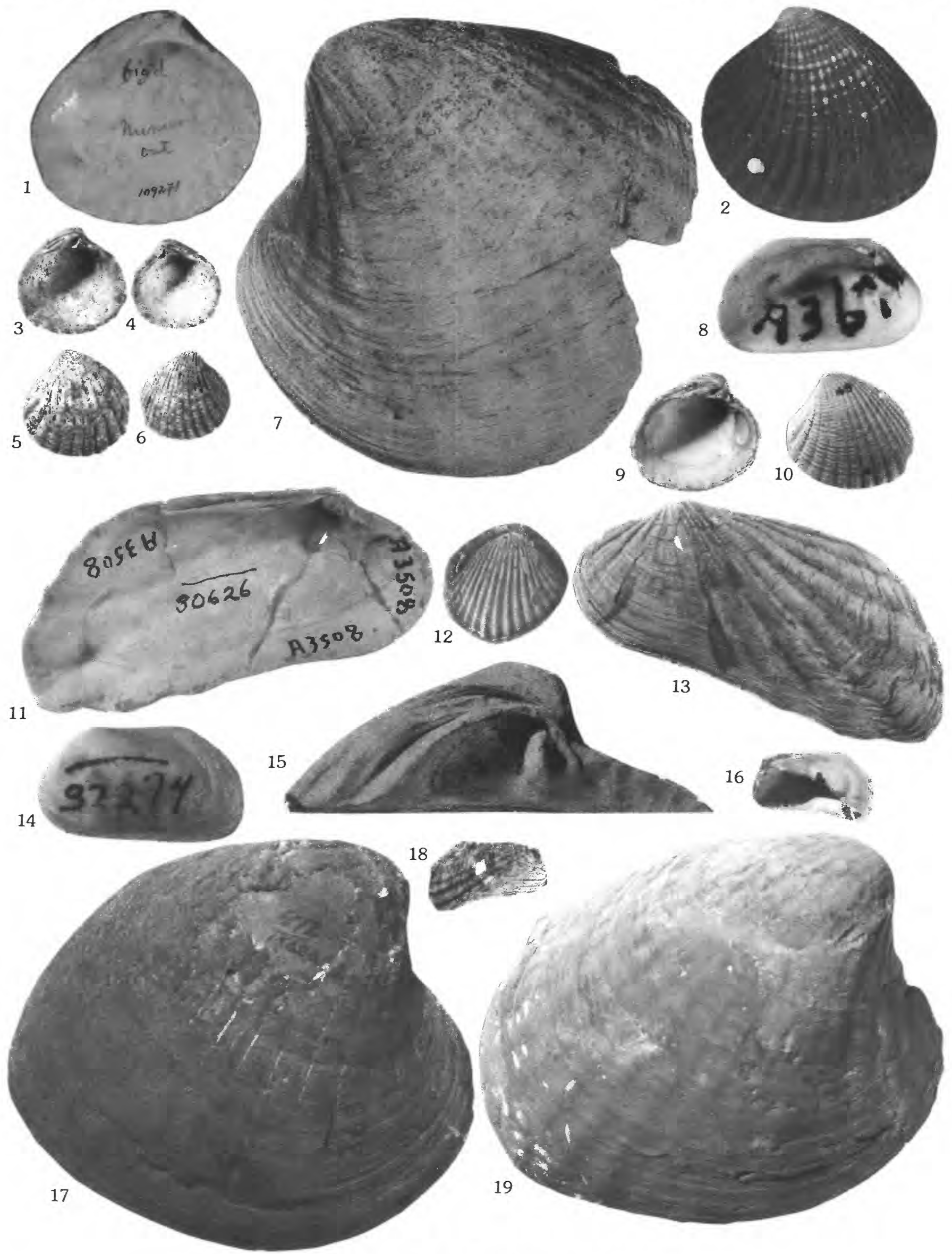

CYCLOCARDIA, VENERICARDIA, BASTEROTIA, CARDITA, MILNERIA 





\section{SELECTED SERIES OF U.S. GEOLOGICAL SURVEY PUBLICATIONS}

\section{Periodicals}

Earthquakes \& Volcanoes (issued bimonthly).

Preliminary Determination of Epicenters (issued monthly).

\section{Technical Books and Reports}

Professional Papers are mainly comprehensive scientific reports of wide and lasting interest and importance to professional scientists and engineers. Included are reports on the results of resource studies and of topographic, hydrologic, and geologic investigations. They also include collections of related papers addressing different aspects of a single scientific topic.

Bulletins contain significant data and interpretations that are of lasting scientific interest but are generally more limited in scope or geographic coverage than Professional Papers. They include the results of resourcestudies and of geologic and topographicinvestigations; as well as collections of short papers related to a specific topic.

Water-Supply Papers are comprehensive reports that present significant interpretive results of hydrologic investigations of wide interest to professional geologists, hydrologists, and engineers. The series covers investigations in all phases of hydrology, including hydrogeology, availability of water, quality of water, and use of water.

Circulars present administrative information or important scientific information of wide popular interest in a format designed for distribution at no cost to the public. Information is usually of short-term interest.

Water-Resources Investigations Reports are papers of an interpretive nature made available to the public outside the formal USGS publications series. Copies are reproduced on request unlike formal USGS publications, and they are also available for public inspection at depositories indicated in USGS catalogs.

Open-File Reports include unpublished manuscript reports, maps, and other material that are made available for public consultation at depositories. They are a nonpermanent form of publication that may be cited in other publications as sources of information.

\section{Maps}

Geologic Quadrangle Maps are multicolor geologic maps on topographic bases in 7 1/2-or 15-minute quadrangle formats (scales mainly $1: 24,000$ or $1: 62,500$ ) showing bedrock, surficial, or engineering geology. Maps generally include brief texts; some maps include structure and columnar sections only.

Geophysical Investigations Maps are on topographic or planimetric bases at various scales; they show results of surveys using geophysical techniques, such as gravity, magnetic, seismic, or radioactivity, which reflect subsurface structures that are of economic or geologic significance. Many maps include correlations with the geology.

Miscellaneous Investigations Series Maps are on planimetric or topographic bases of regular and irregular areas at various scales; they present a wide variety of format and subject matter. The series also includes $71 / 2$-minute quadrangle photogeologic maps on planimetric bases which show geology as interpreted from aerial photographs. Series also includes maps of Mars and the Moon.
Coal Investigations Maps are geologic maps on topographic or planimetric bases at various scales showing bedrock or surficial geology, stratigraphy, and structural relations in certain coal-resource areas.

Oil and Gas Investigations Charts show stratigraphic information for certain oil and gas fields and other areas having petroleum potential.

Miscellaneous Field Studies Maps are multicolor or black-andwhite maps on topographic or planimetric bases on quadrangle or irregular areas at various scales. Pre-1971 maps show bedrock geology in relation to specific mining or mineral-deposit problems; post-1971 maps are primarily black-and-white maps on various subjects such as environmental studies or wilderness mineral investigations.

Hydrologic Investigations Atlases are multicolored or black-andwhite maps on topographic or planimetric bases presenting a wide range of geohydrologic data of both regular and irregular areas; principal scale is $1: 24,000$ and regional studies are at $1: 250,000$ scale or smaller.

\section{Catalogs}

Permanent catalogs, as well as some others, giving comprehensive listings of U.S. Geological Survey publications are available under the conditions indicated below from the U.S. Geological Survey, Books and Open-File Reports Section, Federal Center, Box 25425, Denver, CO 80225. (See latest Price and Availability List.)

"Publications of the Geological Survey, 1879-1961" may be purchased by mail and over the counter in paperback book form and as a set of microfiche.

"Publications of the Geological Survey, 1962-1970" may be purchased by mail and over the counter in paperback book form and as a set of microfiche.

"Publications of the U.S. Geological Survey, 1971- 1981" may be purchased by mail and over the counter in paperback book form (two volumes, publications listing and index) and as a set of microfiche.

Supplements for 1982, 1983, 1984, 1985, 1986, and for subsequent years since the last permanent catalog may be purchased by mail and over the counter in paperback book form.

State catalogs, "List of U.S. Geological Survey Geologic and Water-Supply Reports and Maps For (State)," may be purchased by mail and over the counter in paperback booklet form only.

"Price and Availability List of U.S. Geological Survey Publications," issued annually, is available free of charge in paperback booklet form only.

Selected coples of a monthly catalog "New Publications of the U.S. Geological Survey" available free of charge by mail or may be obtained over the counter in paperback booklet form only. Those wishing a free subscription to the monthly catalog "New Publications of the U.S. Geological Survey" should write to the U.S. Geological Survey, 582 National Center, Reston, VA 22092.

Note.--Prices of Government publications listed in older catalogs, announcements, and publications may be incorrect. Therefore, the prices charged may differ from the prices in catalogs, announcements, and publications. 